\author{
Universidade De São PaUlo \\ Faculdade De Filosofia, Letras E CiênCIas Humanas \\ Departamento De Letras Vernáculas
}

\title{
O ROMANCE O ESCRAVO (1856), DE JOSÉ EVARISTO DE ALMEIDA NO SISTEMA LITERÁRIO PORTUGUÊS
}

\author{
SUSANNE MARIA LIMA CASTRILLON
}




\title{
SUSANNE MARIA LIMA CASTRILLON
}

\section{O ROMANCE O ESCRAVO (1856), DE JOSÉ EVARISTO DE ALMEIDA NO SISTEMA LITERÁRIO PORTUGUÊS}

\author{
Tese apresentada ao Programa de Pós- \\ Graduação em Estudos Comparados de \\ Literaturas de Língua Portuguesa, do \\ Departamento de Letras Clássicas e \\ Vernáculas da Faculdade de Filosofia, Letras e \\ Ciências Humanas, da Universidade de São \\ Paulo, para a obtenção do título de Doutor em \\ Letras.
}

Orientador: Prof. Dr. Helder Garmes 


\section{Ficha Catalográfica}

CASTRILLON, Susanne Maria Lima

O romance O Escravo (1856), de José Evaristo de Almeida no sistema literário portuguê s- F F L CH- USP, São Paulo, 2010.

205p.

Tese- Doutorado- Programa de Pós-Graduação em Estudos Comparados de Literaturas de Língua Portuguesa, do Departamento de Letras Clássicas e Vernáculas da Faculdade de Filosofia, Letras e Ciências Humanas, da Universidade de São Paulo,

Bibliografia: $p$.

1.Sistema Literário Português 2. O Escravo 3. Intertextualidade 4.Bug-Jargal 5. Die Verloburg In St Domingo. 


\section{SUSANNE MARIA LIMA CASTRILLON}

\section{O ROMANCE O escravo (1856), DE JosÉ EVARISTO de ALMEIDA NO SISTEMA LITERÁRIO PORTUGUÊS}

Tese apresentada ao Programa de Pós-Graduação em Estudos Comparados de Literaturas de Língua

Portuguesa, do Departamento de Letras Clássicas e Vernáculas da Faculdade de Filosofia, Letras e Ciências Humanas, da Universidade de São Paulo, para a obtenção do título de Doutor em Letras.

\section{BANCA EXAMINADORA}

Presidente: Prof. Dr. Helder Garmes

$1^{0}$ Examinadora: Profa. Dra. Simone Caputo.

$2^{0}$ Examinador: Prof. Dr. Antonio Mantovani

$3^{0}$ Examinadora: Profa. Dra.Tânia Celestino de Macedo.

4Examinadora:Profa. Dra.Elizabeth.Batista

São Paulo,........de. 
O mundo colonizado é o mundo cindido em dois. A linha divisória, a fronteira, é indicada pelos quartéis e delegacias de polícia. Nas colônias o interlocutor legal e institucional do colonizado, o porta-voz do colono e do regime de opressão é o gendarme ou o soldado. Nas sociedades de tipo capitalista, o ensino religioso ou leigo, a formação de reflexos morais transmissíveis de pai para filho, a honestidade exemplar de operários condecorados o cabo de cinqüenta anos de bons e leais serviços, o amor estimulado de harmonia e da prudência, formas estéticas do respeito pela ordem estabelecida, criam em torno do explorado uma atmosfera de submissão e inibição que torna consideravelmente mais leve a tarefa das forças da ordem. Nos países capitalistas, entre o explorador, o explorado e o poder interpõem-se uma multidão de professores de moral. Nas regiões coloniais, ao contrário, o gerdame e o soldado, por sua presença imediata, por suas intervenções diretas e freqüentes, mantêm contato com 0 colonizado e o aconselham a coronhadas ou com explosões de napalm, a não se mexer. Vê-se que 0 intermediário do poder utiliza uma linguagem de pura violência. O intermediário não torna mais leve a opressão, não dissimula a dominação. Exibe-as, manifesta-as com a boa consciência das forças da ordem. O intermediário leva a violência à casa e ao cérebro do colonizado. Frantz Fanon - Os Condenados da Terra (p.28) 
À minha mãe, companheira, amiga e interlocutora em todos os estágios da vida.

Te amo!

Aos amores da minha vida Emmanuel $e$ Emanuele, autênticos companheiros. Suas interrupções foram freqüentes e insubstituíveis.

Embora nossas vidas sejam agora vividas em países tão diferentes, você continua sendo a fonte da minha mais profunda vontade, Pai.

Te amo! 


\section{AGRADECIMENTOS}

Ao finalizar essa tese, meu porto de lembranças pousa, e se desloca por muitos outros lugares e pessoas, envolventes e apaixonantes, em entrecruzamentos de ideias, sonhos, desejos, estranhezas, dos quais devo mencionar de forma especial, reiteirando os meus agradecimentos:

À Mestre Benilde Caniato, gratidão eterna (in memoriam).

Ao Prof. Dr. Helder Garmes, meu orientador, pela tolerância, precisão e questionamentos críticos, os quais instigaram e fortaleceram a travessia da tese.

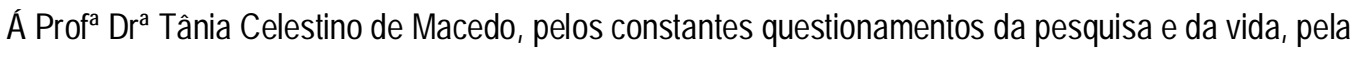
amizade e carinho dedicados e por me apresentar o romance O Escravo.

À Profa ${ }^{\mathrm{D}} \mathrm{r}^{\mathrm{a}}$ Elza Miné, a quem o débito amplia-se e se tornou amizade diuturna.

Ao Avião, protagonista mais apaixonante deste mundo, que me leva pelos ares em encontros confluentes, pele a pele, fogo a fogo, em sua moderna lusíada de Camões, agradeço por compartilhar com a Passageira o movimento do pensamento e por suportar a ansiedade da incompletude que acompanhou essa escrita da tese.

Aos meus irmãos Solange, Cleodemir, Kizo, Fernanda, Suzette, Adriano, Sueele e Thiago pela sensibilidade generosa nos momentos mais difíceis.

Aos primos Flávio e Maribel, antigos cúmplices de vontades e constantes torcedores pelas minhas realizações. 
À Elair de Carvalho, leal amiga, pela desprendida dedicação e apoio irrestrito.

À Maria Apparecida Marcondes, pela acolhida generosa, pela leitura rigorosa, eficiente e sugestiva, pelas incontáveis gentilezas durante o período de escrita.

Ao Renato, Leandro, Sílvio, Miguel, Hugo, Aldrei, Alberto, Camilo, Paulo, Sérgio, Renan, João, Nonata, Marla, pelo calor humano em Sampa.

Aos amigos e companheiros das Parceladas, em especial ao Araguaia, por tornar possível muitas oportunidades de compartilhamento e prazer de epifanias.

Aos companheiros da Adunemat, sempre disponíveis para contribuições.

Aos colegas dos Departamentos de Letras de Pontes e Lacerda e de Cáceres, da Unemat, pelas reiteradas manifestações de apoio e incentivo.

Aos colegas da área de Literatura, cúmplices mais próximos das minhas conquistas.

Ao professores e funcionários da Pos-Graduação e do Departamento de Estudos Comparados de Literaturas de Língua Portuguesa da USP.

À Universidade de São Paulo-USP, pela oportunidade de realização da tese.

À Fapemat, que me concedeu a bolsa de pesquisa, no período de 2008 a 2011. 
Castrillon, Susanne Maria Lima. O romance O Escravo (1856), de José Evaristo de Almeida no sistema literário português. Tese (Doutorado) Faculdade de Filosofia, Letras e Ciências Humanas, Universidade de São Paulo, São Paulo, 2010.

\section{RESUMO}

Com sua ação passada em Cabo Verde, o romance O escravo (1856) de José Evaristo de Almeida está vinculado à história da literatura caboverdiana, sendo considerado por alguns críticos como o primeiro romance nativista daquela literatura. $O$ enfoque aqui proposto procura refletir sobre o seu lugar no âmbito da Literatura Portuguesa, demonstrando que, apesar de ocupar um espaço marginal no sistema literário português, esse romance dialoga, tematicamente, com a literatura européia, na sua relação intertextual com os romances Die Verloburg In St Domingo (O noivado em São Domingos), de Bernd Henrich Von Kleist e BugJargal, de Victor Hugo.

Palavras-Chave: Sistema Literário Português - O Escravo - Intertextualidade - Bug-Jargal Die Verloburg In St Domingo (O Noivado em São Domingos). 
CASTRILLON, Susanne Maria Lima. The movel the Slave (1856), de José Evaristo de Almeida on this portuguese literary sistem. Thesis Faculdade de Filosofia, Letras e Ciências Humanas, Universidade de São Paulo, São Paulo, 2010.

\section{ABSTRAT}

With your action passed in Cabo Verde, The movel the Slave (1856), de José Evaristo de Almeida in entailed at history of the caboverdian literature,considery for any critiques what one nativism movel from that literature. The way of focusing the question there do seek reflected with your position this ambit of Portuguese literature, showing that, althought the occupy one marginal place in this Portuguese literary system, in this movel it dialogue, thematically, with European literary, in its intertextual act of reporting on the movel Die Verloburg In St Domingo (The married in St. Domingo), in Bernd Henrich Von Kleist and Bug-Jargal, in Victor Hugo.

Key-words: portuguese literary system - The Slave - Intertextuality - Bug Jargal - Die Verlogburg In St Domingo. 
CASTRILLON, Susanne Maria Lima. El romance El Esclavo (1856), de José Evaristo de Almeida em el sistema literário portugués. Tesis de Doctorado Faculdade de Filosofia, Letras e Ciências Humanas, Universidade de São Paulo, São Paulo, 2010.

\section{RESUMEN}

Com su acción pasada en Cabo Verde, el romance El esclavo (1856) DE José Evaristo de Almeida está vinculado a la historia de la literatura caboverdiana, siendo considerado por algunos críticos como el primer romance nativista de aquella literatura. El enfoque aquí propuesto procura reflexionar sobre su lugar en el ámbito de la literatura portuguesa, demostrando que, a pesar de ocupar un espacio marginal en el sistema literario portugués, ese romance dialoga, aunque temáticamente, con la literatura europea, de modo más amplio en su relación intertextual con los romances Die Verloburg In St Domingo (El compromiso em San Domingos), de Bernd Henrich Von Kleist y Bug-Jargal, de Victor Hugo.

Palabras Claves: Sistema Literario Portugués - El Esclavo - Intertestualidad - Bug Jargal - Die Verlogburg In St Domingo (El Compromiso en San domingos). 


\section{SUMÁRIO}

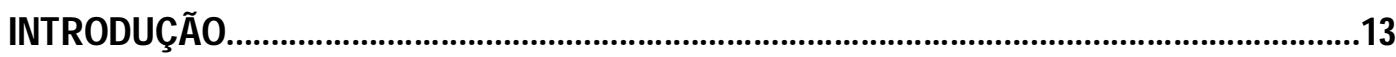

1 UNIVERSO LITERÁRIO E A NOÇÃO DE SISTEMA ........................................................

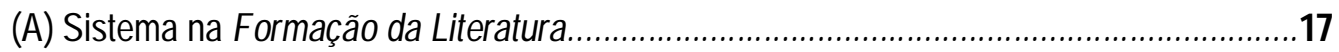

1.1 Os Elementos de Compreensão.......................................................17

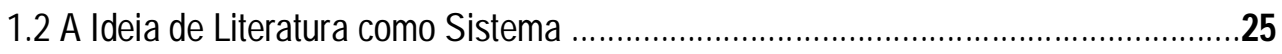

(B) Sistema Literário Português no Romantismo ..........................................................41

1.3.0 Contexto do Sistema Romântico Português .....................................................44

1.3.1 Representantes do Estado Português: Os Intelectuais dos Oitocentos

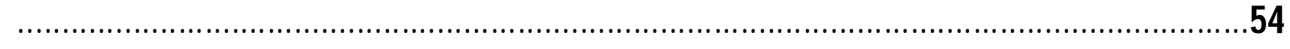

1.3.2 As Ações do Estado na Difusão da Cultura ....................................................60

2 O LUGAR DO ROMANCE O ESCRAVO NO ROMANTISMO PORTUGUÊS......................... 72

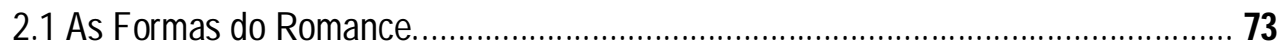

2.2 Temas Recorrentes e Lateralidade no Romance

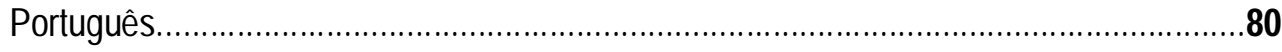

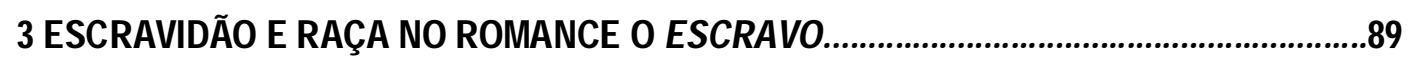

3.1 O Tecido do Discurso Romanesco de O Escravo ................................................97

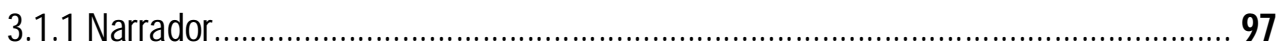

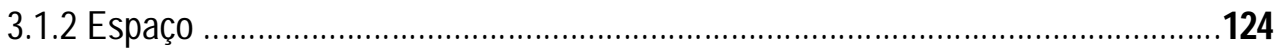




\section{ESCRAVIDAO E RAÇA NO CONTEXTO LITERARIO EUROPEU: O NOIVADO EM SÃO}

DOMINGOS, E BUG-JARGAL, EM DIALOGO COM O ESCRAVO.

4.1 Die Verloburg In St Domingo, de Bernd Henrich Von Kleist e Bug-Jargal de Victor Hugo

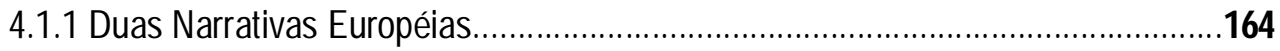

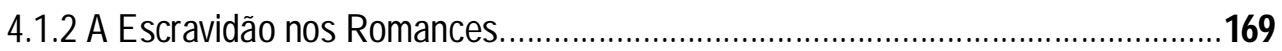

4.1.2.1 Tempo e espaço no tecido romanesco das obras.........................................169

4.1.2.2 O Modo de Contar do Narrador......................................................................

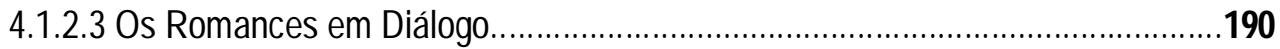

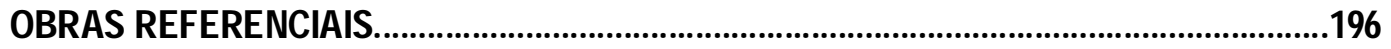




\section{INTRODUÇÃO}


O romance O escravo (1856), de José Evaristo de Almeida, guarda fortes vínculos com a história da literatura caboverdiana, sendo considerado por parte da crítica como o primeiro romance nativista daquela literatura. Apesar de reconhecer o quão representativa é essa obra para a tradição literária caboverdiana, em vista da defesa, ainda que idealisticamente romântica, que se faz da identidade cultural de Cabo Verde, o presente trabalho se debruça sobre a inserção do romance na tradição literária portuguesa. O intuito dessa tese é o de demonstrar que, apesar de ocupar um espaço marginal no sistema literário português, esse romance dialoga tematicamente também com a literatura européia na sua relação intertextual com romances como Die Verloburg In St Domingo ( $O$ noivado em São Domingos), de Bernd Henrich Von Kleist, e Bug-Jargal, de Victor Hugo.

O trabalho está dividido em quatro capítulos. O primeiro capítulo "Universo literário e a noção de sistema" - está dividido em duas partes. Na parte $(A)$, apresenta-se um estudo sobre a noção de sistema no universo literário, tomando as proposições de Antonio Candido, especificamente na obra Formação da Literatura Brasileira: Momentos decisivos (1961). As análises dos elementos de compreensão da obra de arte e de sistema apresentados e discutidos por Antonio Candido são referências para a reflexão do sistema literário português. $\mathrm{Na}$ parte (B) do referido capítulo, focalizam-se as peculiaridades do sistema literário português no período romântico. Concebemse, assim, a relação dialógica entre a obra literária, seu público e os grupos de 
intelectuais dos oitocentos, revelando-se os papéis dos agentes e das instituições que legitimam a cultura. O objetivo principal é o de entender a estrutura desse sistema literário nacional no período romântico, identificando as idéias que o fundamentaram.

No segundo capítulo - "O lugar do romance O Escravo no romantismo português" -, focalizou-se dentro do período romântico português o gênero romance, procurando identificar as formas, vertentes, temas mais recorrentes e marginais do período, fazendo um percurso que vai de 1825 à década de 1860. A partir daí, pode-se observar que o romance ganha formas específicas (romance passional, romance histórico etc.) e cumpre também expectativas distintias (puro deleite e fruição literária, formação moral, afirmação da identidade nacional, estabelecimento de um paradigma civilizatório etc.). Trata-se, por conseguinte, de um capítulo que contempla autores e obras que tratam de temas mais ou menos prestigiados, estando entre os menos prestigiados a escravidão e a raça. Portanto, a análise temática considera o centro e a periferia do sistema literário português, observando o lugar das obras nesse sistema literário.

No terceiro capítulo - "Escravidão e raça no romance O Escravo", analisou-se o romance de José Evaristo de Almeida no tecido do discurso romanesco. Os significados temáticos da escravidão e da raça foram vistos a partir dos pressupostos da teoria de Gérard Genette sobre o discurso narrativo, tendo a história de Cabo Verde como referência contextual.

Finalmente, no quarto capítulo - "Escravidão e raça no contexto literário europeu: $O$ noivado de São Domingos e Bug-Jargal em diálogo com 0 
escravo" - apresentou-se novas questões na representação da raça e das formas de escravidão que vêm à tona com a leitura de outras obras literárias européias, confirmando assim as relações dialógicas entre os sistemas literários português e os outros sistemas literários europeus. Com efeito, o desejo de compreender a história da representação literária da escravidão, no sistema literário de Portugal e de Cabo Verde, dirigiu a pesquisa para a Europa, com o objetivo de se perguntar sobre a efetiva lateralidade de $O$ escravo no âmbito europeu. Para tanto,, estabeleceu-se uma análise comparativa entre o texto de José Evaristo de Almeida e as narrativas Noivado em São Domingos, do alemão Von Kleist; e Bug-jargal, do francês Victor Hugo.

Conclui-se pela inserção de $O$ escravo dentro de uma tradição de romances românticos europeus que trataram da questão racial e escravagista, fazendo com que seu isolamento no cenário literário português seja relativizado. 


\section{UNIVERSO LITERÁRIO E A NOÇÃo DE SISTEMA}


A arquitetura deste trabalho está enraizada no temporal. Todo problema humano deve ser considerado do ponto de vista do tempo.

Frantz Fanon, Pele Negra, Máscaras Brancas

\section{(A)}

\section{SISTEMA NA FORMAÇÃO DA LITERATURA}

\subsection{Os Elementos De Compreensão}

Compreender o romance $O$ escravo em diálogo com os sistemas literários implica debruçar-se sobre a obra Formação da Literatura Brasileira: Momentos Decisivos (1961), de Antonio Candido, que abriga uma de suas formulações mais expressivas sobre o tema. A noção de sistema literário, desenvolvida e aplicada pelo autor, é uma das teorias basilares dos estudos comparados, ainda hoje, no Brasil, que muito contribuiu para a compreensão de como se organizou e se construiu a tradição literária brasileira.

Escrita na década de 1960, esta obra compartilhava de um Brasil pós-Segunda Guerra Mundial, em que se proclamava o princípio de 
autodeterminação dos povos pela Carta das Nações Unidas. A Nação encontrava-se confrontada por uma luta de descolonização mais ampla e por novas estratégias de dominação imperialista, com implicações políticas, sociais, econômicas e culturais.

Antonio Candido desenvolve um estudo com novas interpretações da formação nacional, tendo a literatura como centro. Na Formação da Literatura lança as bases de uma nova maneira de olhar o texto literário que, até então, não tinha registro na tradição crítica da cultura brasileira

No período em que escreveu este trabalho preponderavam as abordagens históricas e sociológicas na investigação da obra de arte literária, mas sua crítica compreendia os problemas estruturais da literatura, privilegiando os valores estéticos. Encontra, assim, um ponto de equilíbrio entre os processos históricos e sociológicos e os métodos de abordagem literária. Parte de uma concepção sociológica contrapondo-se ao método estilístico, e procura demarcar a herança histórico-crítica precedente e incorporar outros elementos, repensando os marcos cronológicos e culturais do surgimento de nossa literatura, seus momentos decisivos, conjuntamente com 0 estabelecimento de um sistema literário.

$\mathrm{Na}$ introdução de A Formação da Literatura Brasileira (1961), ao tratar dos elementos de compreensão da literatura, Antonio Candido declara que devem ser observados os seguintes fatores:

Em primeiro lugar, os fatores externos, que a vinculam ao tempo e se podem resumir na designação de sociais; em 
segundo lugar o fator individual, isto é, o autor, o homem que a intentou e realizou, e está presente no resultado; finalmente, este resultado, o texto, contendo os elementos anteriores e outros, específicos, que os transcendem e não se deixam reduzir a eles. (1961, v. 1, p.26)

Atribui, assim, importância à crítica literária voltada para a análise do vínculo entre a obra e o meio social historicamente determinado, ao lado da análise estética da obra literária. Para o autor, o fator social é concebido como elemento que desempenha um papel constitutivo da estrutura da obra, tornando-o interno a ela. A abordagem crítica deve tomar a obra literária como resultado de um conjunto de fatores sociais, que interfere na constituição desta e na sociedade ao ser publicada. Assim, os fatores externos não oferecem apenas a matéria-prima, atuam também na constituição do que há de essencial na obra enquanto arte literária, que, por sua vez, atua sobre a sociedade. A percepção de literatura, de Antonio Candido, é um todo indissolúvel, tessitura artística elaborada por fatores e formas a um só tempo.

Observar a dimensão social de uma obra tomando por referências lugares, datas, manifestações de determinados grupos, não basta. Há necessidade de compreender essa dimensão social na estrutura da obra, como fator da própria construção artística:

[...] a compreensão da obra não prescinde a consideração dos elementos inicialmente não-literários. O texto não os anula, ao transfigurá-los, e sendo um resultado, só pode ganhar pelo conhecimento da realidade que serviu de base à sua realidade própria. Por isso, se entendimento dos fatores é desnecessário 
para a emoção estética, sem o seu estudo não há crítica, operação, segundo vimos, essencialmente de análise, sempre que pretendemos superar o impressionismo. (1961, v.1, p.27)

Dessa forma, entende que a compreensão da obra literária passa necessariamente pelo entendimento de seu contexto histórico e social, ainda que "a sua importância quase nunca é devida à circunstância de exprimir um aspecto da realidade social ou individual, mas à maneira por que o faz" (1961, v. 1, p.27). Portanto, apesar de valorizar o contexto no qual a obra emerge, não deixa de considerar a primazia do texto:

A crítica se interessa atualmente pela carga extraliterária, ou pelo idioma, na medida em que contribuem para o seu escopo, que é o estudo da formação, desenvolvimento e atuação dos processos literários. Uma obra é uma realidade autônoma, cujo valor está na fórmula que obteve para plasmar elementos não-literários: impressões, paixões, idéias, fatos, acontecimentos, que são a matéria-prima do ato criador [...] No limite, o momento decisivo é o que permite compreendê-la e apreciá-la mesmo que não soubesse onde, quando, por quem foi escrita. Essa autonomia, depende, antes de tudo, da eloqüência do sentimento, penetração analítica, força de observação, disposição das palavras, seleção e invenção das imagens; do jogo de elementos expressivos cuja síntese constitui a sua fisionomia, deixando longe os pontos de partida não-literários. (1961, v. 1, p.26-7)

No texto literário encontra-se o resultado de uma invenção, de um movimento criativo que se serve da linguagem para reinventar a realidade histórica - algo ainda não existente. 
João Alexandre Barbosa (2000) explica que, em Antonio Candido, o miolo histórico-literário é demonstração de uma articulação em que a investigação teórica integra-se com a história na leitura crítica, pois "sem a teoria, a história não seria senão descrição sucessiva de dados e fatos; sem a história, a teoria não deixaria o patamar das especulações generalizadoras" (p.31). E completa:

[...] a validade será sempre uma conquista de cada obra, independente, de alguma maneira da consciência de escritor que, com frequência, tem dificuldades em reconhecer a sua legítima condição na sociedade. Por aí, deste modo, é possível recuperar a frase inicial com valor positivo: o desassossego da atividade literária é próprio da natureza ficcional da literatura. (p.31-32)

Paulo Arantes, também, ressalta o valor da formulação de Candido acerca da internalização que o texto faz do momento histórico:

[...] na concepção enriquecida de Auerbach, isto é, no sentido de exposição, descoberta e apropriação ao qual nosso autor teria acrescentado a função estruturadora da forma, presente naturalmente no âmbito da configuração artística, cuja generalidade se poderia, entretanto, alcançar graças àquela mesma estruturação atuante no sistema das mediações sociais, trampolim paradoxal para a análise interna, na medida em que tais mediações podem ser tratadas como se fossem categorias explicativas desentranhadas da própria obra.(1997, p.40) 
É possível, pois, afirmar que a literatura está integrada aos elementos que constituem a vida social e cultural, da qual o escritor não pode de maneira alguma fugir. A literatura apresenta-se como a forma de expressão que dá equilíbrio e visibilidade ao processo histórico, a partir de sua recriação. A tarefa do intelectual consiste em distinguir o elemento humano na forma da obra, uma vez que:

[...] a literatura é um conjunto de obras, não de autores ou fatores. Como, porém, é integração de elementos sociais e psíquicos, estes devem ser levados em conta para interpretálo, o que apenas na aparência contesta o que acaba de ser dito. $(1961$, v. 1 , p. 27$)$

A literatura é observada como parte integrante da cultura e como tal deve ser pensada. Antonio Candido, como crítico engajado e consciente, entende que o trabalho intelectual é ato político e funciona como arma de denúncia e de libertação.

No capítulo "Direito à Literatura", da obra Vários Escritos (1995), Antonio Candido denomina função humanizadora da literatura o poder que esta tem para atuar na formação do indivíduo:

Alterando um conceito de Otto Ranke sobre o mito, podemos dizer que a literatura é o sonho acordado das civilizações. Portanto, assim como não é possível haver equilíbrio psíquico sem sonho durante o sono, talvez não haja 
equilíbrio social sem a literatura. Deste modo, ela é fator indispensável de humanização e, sendo assim, confirma o homem na sua humanidade, inclusive porque atua em grande parte no subconsciente e no inconsciente. Neste sentido, ela pode ter importância equivalente à das formas conscientes de inculcamento intencional, como a educação familiar, grupal ou escolar [...] A literatura confirma e nega, propõe e denuncia, apóia e combate, fornecendo a possibilidade de vivermos dialeticamente os problemas. Por isso, é indispensável tanto a literatura sancionada quanto a literatura proscrita; a que os poderes sugerem e a que nasce dos movimentos de negação do estado de coisas predominante.

A respeito desses dois lados da literatura, convém lembrar que ela não é uma experiência inofensiva, mas uma aventura que pode causar problemas psíquicos e morais, como acontece com a própria vida, da qual imagem e transfiguração. Isto significa que ela tem papel formador da personalidade, mas não segundo as convenções; seria antes segundo a força indiscriminada e poderosa da própria realidade. Por isso, nas mãos do leitor o livro pode ser fator de perturbação e mesmo de risco. Daí a ambivalência da sociedade em face dele, suscitando por vezes condenações violentas quando ele veicula noções ou oferece sugestões que a visão convencional gostaria de proscrever. (1995, p.242-44)

Assim, considera-se que o lugar na produção literária de um tempo é, antes de qualquer coisa, uma construção elaborada como uma "rede pública" de sentidos, formadora da subjetividade. Nela circulam elementos das experiências dos sujeitos escritores, de suas leituras e das interpretações dessas experiências e leituras. Se essa rede foi, ou ainda é, em alguns casos, minimizada ou mesmo negada, isso se dá por determinações políticas e históricas e não por seu efetivo esgarçamento ou desaparecimento. 
Desde modo, Antonio Candido concebe a literatura como processo de estruturação formal de fatores sociológicos, históricos e psíquicos: "a unidade textual é compreendida como organicidade complexa de múltiplos e às vezes contraditórios componentes" (PEDROSA, 1992, p.132). O trabalho crítico passa a ser compreendido "como interpretação interdisciplinar e subjetiva dos dados cuja significação, porque completamente articulada, nunca é unívoca" (p.132).

\subsection{A IDEIA DE LiteRATURA Como Sistema}

\section{Antonio Candido em Formação da Literatura Brasileira (1961)} desenvolve sua teoria relacionando a literatura produzida no Brasil com outras literaturas, como as europeias, identificando-as como sistemas nacionais coerentes e orgânicos. Desenvolve, nesta obra, o conceito de sistema literário, a partir de uma interpretação histórico-crítica da literatura brasileira.

Concebe a história literária como a elaboração, quase "filosófica" do espírito nacional, ao precisar o que significa a palavra "sistema". Sistematizar a literatura brasileira não seria apenas historiar suas fases, períodos ou obras predominantes, mas encontrar, na história, o sentido nacional da literatura, integrado no vasto plano da tradição Ocidental. Por isso, escreve: "Para nós, foi auspicioso que o processo de sistematização literária se acentuasse na fase 
neoclássica, beneficiando-se da concepção universal, rigor de forma, contensão emocional que a caracterizam" ( $v 1$, p. 21). Para o crítico, um dos perigos do "nacionalismo artístico compromete a universalidade da obra, fixando-a no pitoresco e na matéria bruta da experiência de querê-la (...) empenhada, capaz de servir aos padrões do grupo" (v. 1, p. 21).

O autor parte do conceito de que literatura é fenômeno de civilização e, portanto, instituição social. Considera a literatura brasileira dentro de um contexto sociológico bem-delimitado, do qual ela se ergue como um dos elementos da cultura nacional. Para tanto, estabelece a distinção entre manifestações literárias e literatura nacional, isto é, entre movimentos ou fatos isolados e literatura como expressão orgânica da cultura nacional. Talvez, por isso, e em consequência disto, tenha sido possível a ele deslocar o eixo do período de formação da nossa literatura do barroco para o arcádiconeoclássico-romântico, recusando a periodização formulada pelos adeptos do new criticism. Pode-se dizer que a literatura é condicionada por um determinado conjunto de textos que se tornam literários pela legitimação que recebem do sistema pelo qual circulam, pois

[...] um fato de cultura não surge pronto e acabado, antes se configura ao longo de um processo cumulativo de articulação com a sociedade e adensamento artístico [...] constituição da continuidade literária do Brasil [e da] forma ao conteúdo básico da experiência intelectual brasileira. (ARANTES, 1997, p.21)

Ao delimitar e qualificar os momentos decisivos da formação da 
literatura brasileira, Candido considera-a como um sistema de obras ligadas por denominadores comuns, que são:

[...] as características internas tais como língua, temas, imagens, certos elementos da natureza social e psíquica, embora literariamente organizados, que se manifestam historicamente e fazem da literatura aspecto orgânico da civilização. Entre eles se distinguem: a existência de um conjunto de produtores literários, mais ou menos conscientes de seu papel; um conjunto de receptores, fornecendo os diferentes tipos de públicos, sem os quais a obra não vive; um mecanismo transmissor (de modo geral, uma linguagem, traduzida em estilos) que liga uns aos outros. $O$ conjunto de três elementos dá lugar a um tipo de comunicação interhumana, a literatura que aparece sob este ângulo como sistema simbólico.(1961, v.1, p.23)

Assim, Antonio Candido elenca os diversos componentes de um sistema literário, a que se pode incluir a sociabilidade que se instaura entre escritores, intelectuais e instituições, base de uma vida literária que se articula em espécies de redes de relacionamentos interpessoais, relacionamentos nos quais há espaço para apropriações, para a contradição polêmica, para o compartilhamento de posições estéticas e trocas simbólicas.

O conceito de sistema literário elaborado por Candido foi interpretado por distintos críticos com reações diversas. Por isso, ao publicar a segunda edição de Formação, em 1962, o autor argumenta no Prefácio em defesa de sua tese sobre o sistema literário:

Suponhamos que para se configurar plenamente como sistema articulado, ela [a obra] dependa da existência do 
triângulo "autor-obra-público", em interação dinâmica, e de uma certa continuidade da tradição. Sendo assim a brasileira não nasce, é claro, mas se configura no decorrer do século XVIII, encorpando o processo formativo que vinha de antes e continuou depois. (v.1, p 16)

Em entrevista à Folha de S. Paulo (2006), Antonio Candido declarou que um de seus pressupostos

[...] era que a literatura é, sobretudo, um conjunto de obras, mais do que de autores ou fatores. No caso brasileiro, me pareceu que a análise das obras em perspectiva histórica deveria atender tanto à singularidade estética de cada uma quanto ao seu papel na formação da literatura como instituição regular da sociedade. Tratava-se, portanto, de averiguar quando a conhecida trinca interativa "autor-obra-público" se definiu e se prolongou no tempo pela "tradição", constituindo um "sistema", em contraste com as "manifestações literárias" precedentes. [...] De fato, eu não tinha ainda percebido com clareza que o essencial no tocante às relações da ficção com a sociedade era demonstrar (não indicar apenas) de que maneira as condições sociais são interiorizadas e se transformam em estrutura literária, que pode ser analisada em si mesma. É o processo que denominei "redução estrutural".

Para o autor, pensar a literatura como sistema significaria encerrar o máximo da vida com o máximo da ordem mental, vendo na realidade "um universo de fatos que se propõem e logo se contradizem, resolvendo-se na coerência transitória de uma unidade que sublimam as duas etapas, em equilíbrio transitório" (1961, v. 1, p. 24). 
O princípio que rege o pensamento de Candido é de natureza dialética, pois tudo se dá em processo, numa dinâmica de afirmação, negação e síntese, que já se coloca como nova afirmação - daí o equilíbrio transitório de que fala. Esse movimento dialético da dinâmica literária caminha, na Formação da Literatura Brasileira (1961), no sentido de sua síntese maior, que seria a constituição do sistema literário.

É nessa perspectiva que se encontra a fundamentação teórica de sistema literário, não mais como postulavam os críticos das historiografias literárias anteriores, considerando simplesmente a cronologia das obras e os autores. Assim, a Formação da Literatura Brasileira almeja identificar a fundação, o desenvolvimento e a consolidação do sistema literário brasileiro. Fazendo observar o caráter periférico da Literatura Brasileira em relação às europeias, localiza as origens do sistema literário em meados do século XVIII e considera completa sua formação em meados do século XIX.

Os períodos Arcadismo e Romantismo são considerados, pelo autor, decisivos para a formação do que denomina sistema literário brasileiro, isto é, vê ali a articulação de autores, obras e públicos de maneira a estabelecer uma tradição. Esta gera a continuidade, que dá à produção literária o caráter de atividade permanente, associada a outros aspectos da cultura. Esse modo de ver diverge da historiografia tradicional, porque adota como critério a constituição da literatura como atividade regular na sociedade, e não somente como expressão de algum sentimento nacional.

No Brasil, desde Anchieta, no século XVI, sempre houve a produção de importantes textos literários. No entanto, segundo o autor, somente a partir 
de meados do século XVIII começa a ser possível falar de um esboço de uma literatura propriamente brasileira. Portanto, o seu intuito não foi estudar toda a literatura do Brasil, mas os períodos durante os quais ela adquiriu o caráter de sistema, conforme a definição citada anteriormente. Dessa perspectiva, a literatura passa a ser uma instituição da sociedade, não simples ocorrência de textos, por mais importantes que fossem.

Nesse conjunto, as obras:

[...] entram com todo peso da realidade própria e o contexto se firma a partir de um sistema que as alimentas. Nesse sistema, o movimento constante entre análise e síntese , a erudição e o gosto. O ponto alto é a tendência para integrar os contrários mesmo que o significado histórico do conjunto destoe do caráter singular dos autores estudados. (PRADO, 2003, p. 428) (conferir original)

Ao falar do sistema literário, Antonio Candido mantém sua concepção sociológica, pois entende sua Formação como "uma síntese de tendências universalistas e particularistas [...]" (1961, v I, p. 23), que gera uma "tradição contínua de estilos, temas, formas e preocupações” (p.25), possibilitando, assim, o entendimento de que a formação do sistema não pode ser dissociada do processo de organização do Estado Nacional.

Ao se reportar ao Arcadismo brasileiro, quando o Brasil ainda era Colônia de Portugal, observa que a literatura se tratava de 
[...] um amplo fenômeno de civilização que abrange a Itália, a Espanha, a França, Portugal, o Brasil e outros países. Portanto, no quadro de referências em que ela se enquadra, passamos da 'imitação' para a 'criação' (V.1, p.24).

Esse quadro amplo do universo literário, ligado ao momento inicial de particularização de um sistema, é algo que pode ser identificado hoje nos países africanos de língua portuguesa, salientada também por muitos estudiosos, como: Manuel Ferreira (1989); Pires Laranjeira (1995); Santilli (1991); Caniato (1994); Rita Chaves (1995); Garmes (2004); e Macedo (2008), entre outros. A produção literária dos países de língua portuguesa encontra-se, hoje, a depender da nação, em algum ponto entre a afirmação e a consolidação de um sistema literário autônomo.

Retornando à formulação de Antonio Candido, os árcades brasileiros, para ele, quiseram demonstrar que "eram tão capazes quanto os europeus, mesmo quando procuravam exprimir uma realidade puramente individual, segundo os moldes universalistas do momento estão visando este aspecto" (1961, v. 1, p. 20).

Após 1822, com a Independência, a literatura torna-se arma poderosa de libertação, "encarnada de espírito nacionalista", em que os escritores, conscientes da sua função histórica, expressam suas diferenças e particularidades pelos temas, imagens, e em língua renovada. Essa tomada de consciência do escritor distancia escritores empenhados nesse programa político-literário daqueles que apenas se apresentavam como nativistas, descrevendo paisagens, costumes e terras com o objetivo de informar o leitor- 
outro - o português ou uma "elite de favorecidos" -, sobre as peculiaridades encontradas na Colônia.

A literatura nacionalista, intimamente vinculada à construção do imaginário da Nação, foi determinante nesse momento. A formação da identidade cultural brasileira, no final dos setecentos e nos oitocentos, está imbuída do processo de Independência. Antonio Candido evita cair num nacionalismo ingênuo, observando que o nacionalismo pode comprometer a universalidade da obra, fixando-a no "material bruto da experiência" e no pitoresco. Porém, insiste num nacionalismo crítico, herdado dos românticos, capaz de valorar a obra pelo seu caráter representativo. O nacionalismo, deste ponto de vista, torna-se, na obra literária, fator de eficácia estética, apoia a imaginação e a estrutura da forma.

Carlos Guilherme Mota observa que o nacionalismo, para Antonio Candido, não cedeu às solicitações do tempo reformista-populista, e mesmo em "tempo de produção nacionalista abundante e deformadora, consegue escrever sobre a temática, buscando o conceito adequado" (1980, p. 175).

Para Candido, a consolidação de um sistema literário só se realiza quando se define o caráter que a literatura vai assumir, quanto à diferença pela temática local e pela natureza: "Os sentimentos dominantes na literatura serão, portanto, o nacionalismo, o indianismo e o cristianismo, pois este foi o ideal que dirigiu nossa colonização" (1961, v.2, p. 322).

Considera, ainda, que a fantasia gratuita é prova do amadurecimento da produção literária nos seus elementos envolvidos: de escritores, de públicos e da Nação; ao contrário, a imaturidade da produção 
literária conduz à procura da cor local. Essa imaturidade, ao mesmo tempo, oferece à literatura sentido histórico na construção da Nação que, ao constituir sua estrutura e forma, aparece como organismo autônomo, elemento de autoconsciência e unívoco, requerendo dos escritores a valorização do que era local.

Há um conjunto de aspectos universais e nacionais que formaram a mescla da tradição europeia e da cultura brasileira, como observa Lígia Chiappini

Aunque asociando el Arcadismo com la Colônia y el Romanticismo com el Brasil independente, los românticos consideraban a los árcades como sus antepasados intelectuales. $Y$ es eso lo que Antonio Candido quiere notar, sobre todo depués de la constatación de que paradójicamente la teoría de la literatura brasileña sustentada por los românticos contra el Arcadismo tiene sus fuentes em la obra de los escritores europeos como Garrett y Ferdinand Denis, entre otros, y fue exportada al Brasil por el poeta brasileño Gonçalves de Magalhães y su grupo parisino (1990, p. p.115)

Tais aspectos foram expostos por Antonio Candido, no capítulo "O Nacionalismo Literário", de Formação da Literatura Brasileira (1961):

A independência importa de maneira decisiva no desenvolvimento da idéia romântica, para a qual contribuiu pelo menos três elementos que se pode considerar como redefinição de posições análogas do Arcaísmo: (a) desejo de exprimir uma nova ordem de sentimentos, agora reputados no 
primeiro plano, com o orgulho patriótico, extensão do antigo nativismo; (b) desejo de criar uma literatura independente, diversa, não apenas uma literatura, de vez que, aparecendo o Classicismo como manifestação do passado colonial, o nacionalismo literário e a busca de modelos novos, nem clássicos nem portugueses, davam um sentimento e libertação relativamente à mãe-pátria; finalmente (c) a noção já referida de atividade intelectual não mais como valor do brasileiro e esclarecimento mental do Brasil, mas tarefa patriótica na construção nacional. (v. 2, p. 11)

Cultiva, assim, um quadro de referências rico e diferenciado que leva em conta o que se criou de valor nas literaturas brasileira e portuguesa. Ele sabe que o Brasil conectado com outros países dialoga e se apropria de traços de outras culturas. Eliminar esses diálogos seria impossível, o que não significa que a cultura brasileira é uma cópia servil dos moldes importados, tão pouco aceitando a ingenuidade do nativismo - mítico de brasilidade. No último capítulo de Formação (1961, v.1, p. 331) enfoca a questão da cópia original em Santiago Nunes Ribeiro, dizendo que os fatores sociais forçam a produzir algo específico, como uma cópia, porém não ao pé da letra, mas como resultado do choque entre culturas, um entre-lugar de imitação inevitável e reação original. Portanto, demonstra a impossibilidade de a literatura brasileira ser apenas reflexo da europeia. Candido lembra que "a nossa literatura é galho secundário da portuguesa", e esta, "por sua vez arbusto de segunda ordem no jardim das Musas", e complementa, "comparada às grandes, a nossa literatura é pobre e fraca. Mas é ela, não outra, que nos exprime” (v.1, p.8).

Nessa perspectiva, aponta para a necessidade de se ter uma literatura nacional que possa oferecer percepções ao homem brasileiro, daquilo 
que efetivamente é e de suas potencialidades. Reforça a ideia da literatura como uma síntese de tendências presentes na fantasia, na imaginação, na fuga do real, na realidade histórica recriada no seu tempo e lugar.

Considera que a literatura brasileira possui mais vínculos fortes com a vida nacional do que os países com suas culturas já estabelecidas, pois "estas se prendem às produções do espírito ao conjunto das produções culturais, mas não a consciência, ou a intenção, de estar fazendo um pouco de nação ao fazer literatura" (CANDIDO, 1961, p.18).

A ideia de "integração" orgânica é a que melhor caracteriza a tendência básica do pensamento de Antonio Candido. Conceito eminentemente histórico, por implicar um acrescentamento ou enriquecimento gradativo e, portanto, um processo temporal, o crítico concebe a história literária por analogia com um corpo, que se vai gestando aos poucos, autodesenvolvendose, diferenciando-se, e, ao mesmo tempo, se "integrando" como um todo maior, como um conjunto harmônico e unitário, cada vez mais consciente de si mesmo. Um processo de elaboração intelectual, de autoconsciência, sem o qual as aquisições literárias correriam o risco de se dispersar ou se descaracterizar. É exemplo dessa sua concepção viva o papel que ele atribui à crítica brasileira do tempo do Romantismo: "quase toda muito medíocre", como salienta, mas de inegável importância histórica, sobretudo por ter desenvolvido:

[...] um esforço básico no setor do conhecimento da nossa literatura, promovendo a identificação e avaliação dos autores do passado, publicando as suas obras, traçando as suas bibliografias, até criar o conjunto orgânico do que hoje 
entendemos por literatura brasileira - um cânon cujos elementos reuniu, para que Sílvio Romero o definisse. (1961, v. 2, p. 328, grifo nosso)

Antonio Candido sabe ver o mérito de uma obra como o "Curso elementar de literatura nacional', de Fernandes Pinheiro (1862), cuja "limitada inteligência", como observava, "transparece a cada passo, no convencionalismo dos juízos, na ênfase vazia do estilo, na incapacidade de dar vida aos elementos biográficos" (1961, v.2, p. 352-53). O cônego observou a literatura do Brasil com medo da literatura nova, mal contemplando os jovens já consagrados na opinião pública. Porém, Candido vê, aí, que há um esforço de sistematizar uma realidade se guardando "nas reticências prudentes da obra". Compara o livro do cônego ao Curso da Literatura Portuguesa e Brasileira de Sotero dos Reis (1866-1873), destacando que é uma importante obra para o tempo em que a literatura é "expressão da sociedade" [...] "do belo intelectual por meio da palavra escrita". Observam-se, aqui, os elementos da obra: "um externo, outro interno, um histórico, outro estético, ordenados e apreciados no texto" (1961, v.2, p. 352). E completa: "primeiro livro coerente e pensado de história literária, fundindo e superando o espírito de florilégio, de biografia e de retórica pela adoção dos métodos de Villemain. Merece, portanto, muito mais do que Ihe tem sido dado" (v.2, p. 352). No caso, diz respeito a um elo da cadeia resultante de outra série evolutiva, que preparava a concepção moderna de história literária:

Visto de hoje, esse esforço semi-secular aparece coerente na sucessão das etapas. Primeiro, o panorama geral, 
o 'bosquejo', visando a traçar rapidamente o passado literário; ao lado dele, a antologia dos poucos textos disponíveis, o 'florilégio', ou 'parnaso'. Em seguida, a concentração em cada autor, antes referido rapidamente no panorama: são as biografias literárias, reunidas em 'galerias', em 'panteons'. Ao lado disso, um incremento de interesse pelos textos, que se desejam mais completos; são as edições, reedições, acompanhadas geralmente de notas explicativas e informação bibliográfica. Depois, a tentativa de elaborar a história, o livro documentado, construído sobre os elementos citados. (v.2, p. 348)

Antonio Candido mostra como foi a teoria da literatura brasileira de Ferdinand Denis (1798-1890), que "projetou", por assim dizer, todo o desenvolvimento da nossa literatura. Há uma valorização de obras, tendências e doutrinas, necessária do ponto de vista histórico, por exprimir uma linha, uma continuidade e uma tradição, sem a qual não se pode conceber a existência de uma literatura como algo que se vai constituindo pelo estímulo do exemplo e do aprofundamento da herança recebida.

Emerge, assim, o estudo do processo de formação da literatura brasileira, compreendido na natureza de seus elementos constitutivos, articulados num complexo entrelaçamento de culturas, que esboça anseio e busca de uma identidade própria. O elemento português participa dessa composição pela força imperiosa de uma ideologia que tinha a seu favor vários instrumentos a serviço do projeto de dominação: a língua, a religião e o poder econômico. A cultura ameríndia e a africana atuaram nesse processo de formação, geraram uma transformação da sensibilidade, favorecendo um modo 
de ser que implicou a criação literária, embora muitos escritores continuassem a ser seduzidos pelos elementos estéticos da tradição clássica erudita.

Torna-se evidente que o Brasil, enquanto Colônia de Portugal, ao receber elementos essenciais da cultura europeia, é sua parte integrante. Com a sua Independência, é notado como país novo e atrasado em relação à civilização europeia, híbrido e escravocrata. Porém, ao analisá-lo em contraste com a modernização industrial e liberal, Candido continua a dialogar com o mundo europeu e a buscar sua expressão brasileira, não num somatório, mas em um processo contínuo de ressignificação.

Pode-se apreender das observações de Antonio Candido que a predominância do elemento europeu é fator determinante na natureza cultural do país, mas que, considerado a partir do elemento artístico, é subvertido e transfigurado. A subversão não elimina o elemento europeu da cultura, mesclao, hibridiza-o à maneira necessária para se forjar uma identidade cultural.

A perspectiva crítica de Candido sobre o processo de formação da cultura brasileira sustenta-se simultaneamente nas dependências

[...] das metrópoles colonizadoras e imperialistas, mas capaz de, a partir mesmo do que elas impõem, reelaborar traços originais. Deste modo,pode-se pensar que a questão da Nacionalidade como entre-lugar, configurando a tensão. (PEDROSA, 1992, p.131)

É importante destacar, conforme esclarece Benjamin Abdala (2001, p. 361-62), que a literatura do Brasil estava, irremediavelmente, integrada às literaturas europeias e às derivadas destas, mas os românticos queriam rejeitar 
esse vínculo, procurando um ponto de partida idealizado nas terras brasileiras, pois o momento era de afirmação política da diferença e do reconhecimento da Independência, no plano do imaginário. A consciência de que a diferenciação do sistema vinha das condições concretas da produção literária brasileira, que, ainda assim, se mantinha em diálogo estreito com as literaturas europeias, só ocorreu com o tempo, na consolidação do projeto do modernismo brasileiro. Portanto, a literatura brasileira romântica marcada pelo modelo europeu estava fortemente atrelada ao processo colonial, já não no plano político, mas sim cultural. Essa condição subalterna da literatura romântica é observada por Candido, ao considerar como os escritores daquele momento tomaram o tema do indianismo:

Em nossos dias, o neo-indianismo dos modernos de 1922 (precedido por meio do século de etnografia sistemática) iria acentuar aspectos autênticos da vida de índio, encarando-o não como gentil- homem embrionário, mas como primitivo, cujo interesse residia precisamente no que trouxesse de diferente, contraditório em relação à nossa cultura européia. $O$ indianismo dos românticos, porem, preocupou sobremaneira em equipará-lo qualitativamente ao conquistador, realçando ou inventando aspectos do seu comportamento que pudessem fazê-lo ombrear com este - no cavalheirismo, na generosidade, na poesia. (1961, v. 2, p.19)

Um quadro importante do romantismo é a falta de um público leitor esclarecido e dotado da consciência artística fortalecida, capaz de analisar os 
escritores, pois não bastava "o senso de missão" para criar uma grande literatura.

Paulo Arantes reitera essa falta, em seu estudo sobre o princípio da Formação, ao observar que Antonio Candido reordena os problemas gerais na Formação da literatura brasileira, precursoramente apresentados por José Veríssimo. Para Arantes, estava "a meio caminho da 'seriação das ideias' [...] à luz do modelo europeu de cultura integrada [...] e da articulação do sistema literário posta em perspectiva pela ideia de Formação" (1997, p. 24).

A superação efetivou-se com Machado de Assis, que se empenha em combinar o singular - a realidade brasileira - com o universal - os padrões dos países europeus - permanecendo independente dos modismos, pois foi "um acontecimento de tal modo decisivo no nosso panorama literário, exigindo a revisão de valores, transformando por completo a visão de passado bem como o juízo da atualidade próxima" (ARANTES, 1997, p.28).

A obra, enfim, atingiu uma expressividade que fez o leitor brasileiro se identificar e compreender, por exemplo, a duplicidade de um Brás Cubas. Conforme Candido:

Se voltarmos porém as vistas para Machado de Assis, veremos que este mestre admirável se embebeu meticulosamente da obra dos predecessores. A sua linha evolutiva mostra o escritor altamente consciente, que compreendeu o que havia de certo, de definitivo, na orientação de Macedo para a descrição dos costumes, no realismo sadio e colorido de Manuel Antonio, na vocação analítica de José de Alencar. Ele pressupõe a existência dos predecessores, e esta 
é uma das razões da sua grandeza: numa literatura em que, a cada geração, os melhores começam da capo e só os medíocres continuam no passado, ele aplicou o seu gênio em assimilar, aprofundar, fecundar o que havia de certo nas experiências anteriores. Este é o segredo da sua independência em relação aos contemporâneos europeus, do seu alheamento às modas de Portugal e França. (1961, v. 2, p.117-8)

Assim, não é de todo pertinente o estudo apenas das relações de um autor sobre o outro, mas o estudo dos índices (ou signos) de uma integração de temas, estilos e preocupações estéticas e ideológicas, na constituição de uma literatura nacional. Nesse processo, a tomada de consciência crítica representa a continuidade, constantemente retomada e aprofundada pela própria crítica, que toma consciência de si como história literária e é "a função afetivamente desempenhada pela armadura teórica da Formação" (LIMA, 1992, p. 162).

O valor superior da obra de Antonio Candido reside, precisamente, na compreensão desse fenômeno da existência histórica da literatura brasileira, pois procura reconstituir a coesão do processo literário, como ele mesmo salienta (1961, v.2, p. 331), e acrescenta:

[...] longa e constante foi, com efeito, elaborar uma história literária que exprimisse a imagem da inteligência nacional na seqüência do topo - projeto quase coletivo que apenas Sílvio Romero pôde realizar satisfatoriamente, mas para o qual trabalharam gerações de críticos, eruditos e professores, reunindo textos, editando obras, pesquisando biografias, num 
esforço de meio século que tornou possível a sua História da Literatura Brasileira, no decênio de 80. (p. 348)

A "história da literatura brasileira" aparece, assim, como coroamento, sistematização de um processo e termo final de uma longa evolução. A história é, propriamente, 'sistema': "um sistema de obras ligadas por denominadores comuns" (1961, v.1, p. 17). A partir dessa noção, Antonio Candido acaba por identificar como se formou o cânone da literatura brasileira. Demonstra como o sistema literário brasileiro se moldou gradativamente ao espírito e à sensibilidade da Nação, ao mesmo tempo em que moldou esse espírito e essa sensibilidade. E pelo exame desta "armadura teórica" compreende-se que a "ideia do sistema está subordinada ao primado da coesão" (LIMA, 1992, p.165), o que se considera aqui a marca do compromisso de Antonio Candido com a vida nacional no seu conjunto.

\section{(B) Sistema LiteráRIO PORtuguês No Romantismo}

La idea de que los fenómenos semióticos, es decir, los modelos de comunicación humana

regidos por signos (tales como la cultura, el

lenguaje, la literatura, la sociedad), pueden entenderse y estudiarse de modo más adecuado si se los considera como sistemas más que como conglomerados de elementos dispares, se ha

convertido en una de las ideas directrices de nuestro tiempo en la mayor parte de las ciencias 
A explanação do fenômeno literário em Portugal no período do Romantismo (1825-1870) realiza-se, aqui, levando-se em conta sua interpenetração com a política e outras manifestações sociais e culturais. $\mathrm{O}$ sistema literário português pode ser lido em analogia aos acontecimentos e fatores que ocorrem em outros sistemas socioculturais.

Como observado na obra de Antonio Candido, seu sistema literário nacional se faz por uma organicidade, que tem conscientemente em seu horizonte, a identidade nacional. Se no caso do Brasil, a nacionalidade foi elemento central na construção do sistema, em Portugal o processo se deu de forma mais estendida no tempo, permitindo que o sistema se formasse sem a premência temporal exigida dos brasileiros. Quando o Brasil consolida seu sistema literário no século XIX, há muito que Portugal consolidara o seu. Portanto, não cabe aqui tratar da formação do sistema literário português, mas sim de sua situação no século XIX. No entanto, para entender melhor essa situação, remontaremos ao século XVIII, que terá os seus fundamentos iluministas e liberais presentificados no Romantismo Português.

\subsubsection{CONTEXTO Do Sistema RomÂntico PORTUGUÊS}


Desde a primeira metade do século XVIII, indivíduos como D. Luís da Cunha, Luís Antônio Verney e Ribeiro Sanches, considerados introdutores do iluminismo e do utilitarismo em Portugal, elaboravam escritos que identificavam "o atraso cultural do Reino como o principal obstáculo a ser superado no processo de inversão de sua decadência econômica" (SILVA, 2006, p. 5). Defendiam uma série de reformas baseadas nas "luzes da razão moderna" como a "única maneira de garantir o progresso nacional" (SCHWARCZ, 2002, p.89).

Entretanto, foi no reinado de D. José I (1750-1777), sob a administração do Marquês de Pombal, que as reformas propostas pelo iluminismo português saíram do âmbito teórico para o da prática. Seu objetivo era fortalecer o Estado monárquico absolutista "através de um programa geral de reorganização da estrutura administrativa [buscando], por meio de uma centralização racional das funções e atribuições dos órgãos competentes, torná-la mais eficaz" (LYRA, 1994, p.35). Segundo José Vicente Serrão (1986), o período Pombalino compreendeu um projeto político desenvolvido no reinado de José I, levado a cabo "por um conjunto de homens e entidades institucionais, unidos numa espécie de rede de solidariedades políticas e pessoais, que tinha por centro a figura do Marquês de Pombal" (p.12). Enquanto projeto político representou uma convergência de ideias, de objetivos e de projetos de intervenção entre esse grupo socioprofissional e outras pessoas que "encontram na existência dum Estado forte e na governação política de Pombal as oportunidades de se realizarem" (SERRÃO, 1986, p.12). 
Isso demonstra que não se podem creditar todas as ações postas em prática no reinado de $\mathrm{D}$. José I, única e exclusivamente à figura de Pombal. A seu lado operava uma equipe, imediatamente vinculada ao Estado, que Ihe dava sustentação administrativa e política. Do ponto de vista da organização e funcionamento institucionais, o governo pombalino introduziu significativas mudanças, gerando uma nova realidade política. No setor econômico, procurou fortalecer o mercantilismo comercial aliado ao poder absoluto do Rei, como alternativa de livrar o reino da dependência inglesa. Visava "introduzir indústrias no país, tornar o comércio rentável e, ainda, conseguir o melhor aproveitamento do ouro que vinha do Brasil" (SCHWARCZ, 2002, p.96). Como Portugal era uma nação essencialmente agrícola, centrou esforços para modernizar e dinamizar tal setor, com o intuito de levá-lo à autossuficiência, mais precisamente no que se refere à produção cerealífera. Esta atitude tinha por fim dificultar ao máximo as importações, como também proteger a produção nacional (SERRÃO, 1986, p.242-45).

Dentre todas as reformas propostas por Pombal, a da educação foi a que teve maior repercussão social. Compreendendo o ensino como "peça fundamental da promoção da pública prosperidade e da consequente superação dos obstáculos ao progresso do Reino" (SILVA, 2006, p.12), Pombal viu na expulsão dos jesuítas a possibilidade de instituir um ensino mais racional, que priorizasse a integração do indivíduo no Estado. Foram criadas aulas régias de latim, grego e retórica. Em 1761, surgiu o Colégio dos Nobres, que tinha por objetivo "proporcionar aos descendentes das famílias aristocráticas uma formação mais moderna, com novo elenco de matérias" (SCHWARCZ, 2002, p. 105), atrelado aos novos conhecimentos científicos em 
voga na Europa, tornando a velha nobreza "útil" ao Estado e à sociedade em geral (SILVA, 2006, p.12). Para completar o quadro, em 1772 veio a reforma da Universidade de Coimbra, na qual os métodos da educação jesuítica foram radicalmente reformulados. Passou-se a enfatizar as ciências físicas e matemáticas. Criou-se uma nova faculdade de Filosofia, que concentrou suas atuações nas Ciências Naturais (química, zoologia, botânica e mineralogia). O impacto das mudanças pode ser observado pelo considerável aumento no número de matrículas na instituição (CARVALHO,In: MACHADO, 2003, p.66-7). Constata-se que a reforma educacional pombalina visava racionalizar e secularizar o ensino, bem como promover o desenvolvimento do conhecimento tecnicocientífico no Reino luso. Entretanto, por falta de especialistas civis, não foi possível deslocar 'os velhos lentes', em sua maioria religiosos, imbuídos do antigo espírito docente das salas de aula. Isto demonstra que a Igreja não perdeu de forma abrupta seu status na esfera educacional.

Nesse contexto criou-se, também, a Real Mesa Censória (1768), um órgão fiscalizador encarregado de selecionar os livros, nacionais e estrangeiros, que podiam circular no Reino e principalmente nas Colônias. Como Portugal dependia economicamente da produção colonial, temia que obras de cunho mais radical e democrático desenvolvessem o ideal de liberdade em seus domínios ultramarinos (BUESCO, 1997, p.35). Autores como Rousseau foram proibidos em todo território português. Compreender as reformas pombalinas é importante por dois motivos: (a) porque refletem o momento de transição da desmistificação do poder em Portugal, em que se defendia a origem divina do Poder Régio, ao mesmo tempo em que se procurava modernizar e racionalizar a administração estatal, para torná-la mais 
eficiente; e (b) por serem elas responsáveis pela implementação de um processo de racionalização que transformou a mentalidade lusa.

Com a morte de D. José I em 1777, chegou ao fim a administração de Pombal. Ao rei sucedeu sua esposa, D. Maria I, cujo governo foi marcado por um ambiente cultural, político e intelectual hostil ao legado pombalino. A criação da Academia Real de Ciências, em 1779, tinha por meta incentivar e difundir estudos variados, desde literatura e história até as ciências naturais, agricultura e economia, que dessem uma feição mais racional e técnica à produção e fomentassem uma roupagem utilitária ao Estado. Com a crise do sistema colonial, diante da independência das colônias inglesas na América (1776), a ideia era incentivar os estudos mais pragmáticos da natureza das colônias, com vistas a tornar a administração cada vez mais lucrativa e efetiva. Supunha-se que toda pesquisa deveria conduzir a uma finalidade prática e resultar em retorno material ou pecuniário à Coroa portuguesa. Por isso mesmo, as principais linhas de pensamento e de ação da Academia Real de Ciências visavam a uma nova orientação para a política colonial, que assimilava elementos do pensamento da época, no que se referia ao incremento da produção, sem abrir mão do mercantilismo e do "exclusivo colonial".

A situação agravou-se na Regência de D. João, em razão da política de expansão continental napoleônica que, em 1806, havia "dominado a Suíça, penetrado na Itália, atravessado a Alemanha e entrado na Polônia e em Viena" (SCHWARCZ, 2002, p.193). Receando não apenas uma invasão iminente em suas fronteiras continentais, mas também a perda do Brasil e da consequente ruptura do sistema colonial, o governo luso optou por estreitar seus vínculos 
com a Inglaterra e transferir, em 1807, 'provisoriamente' sua Corte para o território americano. D. Maria I, após a morte de seu primogênito e herdeiro, D. José, no ano de 1788, começou a dar sinais de demência, o que a leva a perder o controle do governo, tendo seu filho D. João, em 1792, sido nomeado príncipe regente de Portugal. Com a transmigração da Corte para o Brasil, Portugal perdeu o posto de centro político-administrativo do império, bem como teve que conviver, no âmbito interno, sob o pretexto de comandar as forças armadas contra a França, com uma regência britânica.

Em 1820, com o movimento liberal ocorrido na cidade do Porto, ergueram-se duas bandeiras: de um lado, o "constitucionalismo, tão em voga naqueles tempos", e, de outro, "a soberania nacional que, nesse caso, implicava o retorno de D. João VI" (SCHWARCZ, 2002, p.345). No mês seguinte, a cidade de Lisboa aderiu ao movimento dando-lhe mais ênfase. No final do mesmo ano, decidiram realizar eleições para escolher os representantes das Cortes, que teria como meta principal redigir a Carta Constitucional da Nação e estabelecer um novo governo - Regência - que funcionaria até o regresso do monarca. Segundo Silva Dias (1982, p.21), tal movimento não pode ser compreendido como uma revolução liberal burguesa, uma vez que seu contingente fora composto por diversos núcleos da população. Ao lado dos comerciantes e dos profissionais liberais, havia os fidalgos e uma parcela do alto funcionalismo, todos descontentes com o rumo econômico-político perfilado pela Nação.

Não havia uma homogeneidade entre os defensores da ideologia liberal em Portugal, pois, ao lado dos liberais radicais, fortes em cúpulas, mas extremamente débeis quanto à base de apoio, encontram-se os liberais 
gradualistas, com a força do comércio urbano e das profissões jurídicas; e os liberais moderados com largo apoio da burguesia, da nobreza, do clero, do funcionalismo e das profissões livres. Enquanto uns optavam pelo constitucionalismo à inglesa, outros optavam pelo modelo jacobino, e outros ainda optavam por um modelo misto (DIAS, 1982, p.21). Em meio a essa "família liberal desunida, a burguesia era uma fracção minoritária, mesmo em Lisboa e no Porto, mal se podendo falar dela, em termos de massas, fora do litoral oeste, entre as duas cidades capitais" (DIAS, 1982, p.21). Outra característica marcante do movimento foi a pouca participação das camadas populares, que se mostraram impassíveis ao longo do processo 'revolucionário', evidenciando, assim, toda sua aura elitista (SERRÃO, 1982, p.11).

Este movimento é conhecido pela História como Revolução do Porto, ou simplesmente como vintismo. Seus representantes comandaram o cenário político-administrativo em Portugal de 1820 até 1823, ano em que o movimento reacionário, conhecido como Vila-Francada, restabeleceu oficialmente a antiga ordem. A manutenção do regime monárquico fazia parte dos planos dos liberais vintistas, pois acreditavam que só através da permanência da figura do rei, agora guiado pelos preceitos constitucionais, se poderia manter a integridade das possessões ultramarinas lusas e restituir o posto de centro administrativo do império a Portugal (ALEXANDRE, 1982, p.294).

Herdeiro do iluminismo do século XVIII, o nascente liberalismo luso possuía mais uma roupagem regeneradora que uma postura caracterizadamente radical, "ele tendia para um compromisso entre o antigo e o novo, entre a estabilidade (imperial) e o impulso removente de um 
nacionalismo reverdecido e potenciado pela ideia-força da comparticipação nacional na coisa pública" (SERRÃO, 1982, p.4-5). Os liberais de 1820 procuraram implementar reformas no âmbito administrativo, que possibilitassem a recuperação do setor financeiro e fortalecesse o Estado, não mais sob a égide do absolutismo, mas da monarquia constitucional. De fato, o governo vintista visou racionalizar a esfera burocrática e equilibrar os gastos públicos. Organizar o orçamento e dinamizar o aparelho estatal era o foco principal dos 'revolucionários', mas, mesmo com as reformas, o governo não conseguiu livrar o país da crise financeira que assolava sua esfera econômica. Para poder sanar seus gastos, o Estado teve de recorrer à velha política de emissão de papel moeda, sem a contrapartida de reservas, e a contrair empréstimos no exterior. A situação agravou-se com a perda do mercado brasileiro, após sua Independência em 1822 (RUIZ, 1982, p.177-84). O governo se viu obrigado a intensificar a carga tributária dos produtos importados e de primeira necessidade, como os cereais, a fim de honrar seu orçamento. $O$ aumento dos impostos prejudicou uma boa parcela do comércio português, além de auferir um duro golpe na população mais pobre, que viu os preços dos alimentos serem inflacionados. Com isso, cresceu o sentimento de insatisfação no âmbito social, que culminou no movimento reacionário denominado VilaFrancada, ocorrido em 1823, e que pôs fim ao Governo Constitucional, restabelecendo a antiga ordem.

Victor de Sá (1982, p.27) diz que a primeira fase do liberalismo português se destacou por ser mais política que econômica, uma vez que as Cortes adotaram medidas protecionistas e proibiram as importações de inúmeros produtos alimentícios. Além disso, ao mesmo tempo em que 
elaboraram uma Constituição que pregava o direito de os povos escolherem sua forma de governo, fizeram de tudo para manter intacta a estrutura colonial, necessária para livrar o aparelho estatal da intensa crise financeira. A liberdade não era para todos os indivíduos do vasto império português. Esses elementos evidenciam não apenas o caráter específico do liberalismo luso, mas também a herança de seus ideólogos com o iluminismo do século XVIII, pois observa-se, em suas propostas, que estas giram em torno de uma idéia central: racionalizar o setor administrativo para fortalecer o aparelho estatal.

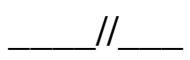

O Estado Português, em 1815, era uma monarquia absoluta sob o comando de D. João VI, condicionada pelas leis fundamentais do reino, pela religião e pela moral. Com a revolução liberal, elaboraram-se as diretrizes para uma política cultural, cuja meta visava subjugar toda a atividade artística aos fins políticos, transformando a produção cultural em um meio de divulgação do Estado-Nação Português. Uma das forças mais acirradas se dá no âmbito da literatura, com o papel dos agentes e das instituições que a legitimaram.

Nesse período, houve uma tendência [irregular e assistemática para a convergência de idéias românticas, não puramente literárias ou artísticas, mas de contaminação política subordinada aos ideais do Liberalismo. Com as mudanças políticas e as insurreições que se deram ao longo da metade do século XIX, em vários países da Europa, incluindo Portugal, o ideal romântico sofre as suas alterações, surgindo naturalmente marcado por um espírito revolucionário e oposicionista aos regimes tendenciosos e totalitários. 
Há também uma tomada de consciência da decadência política e cultural do país, fruto das invasões francesas, da ausência da corte, da ostensiva presença militar inglesa, da perda do Brasil, das revoluções e guerras e das contradições do recém-implantado regime constitucionalista, que abalaram a identidade nacional: a pátria tem uma realidade instável, precária e corre o risco de se extinguir. A "obsessão temática capital" do século XIX português torna-se a de "repor Portugal a sua grandeza ideal tão negada pelas circunstâncias concretas da sua medíocre realidade econômica, política, social e cultural" (LOURENÇO, 1988, p.87).

Saraiva e Lopes, em História da Literatura Portuguesa (1985), defendem que o movimento Romântico:

Data-se habitualmente de 1825, ano da publicação em Paris do Camões de Garrett[...]. Mas esta obra não teve sequência imediata na nossa literatura. Só depois do regresso dos emigrados se verifica o fluxo contínuo de uma corrente literária diferente. É preferível marcar o início do Romantismo em Portugal no ano de 1836, em que se publica $A$ Voz do Profeta, de Herculano [...] em que aparecem as primeiras traduções de Walter Scott, e em que Os Ciúmes do Bardo e a Noite do Castelo, de Castilho [...] denunciam o triunfo entre nós do gosto literário. É no mesmo ano que Passos Manuel [...] abre caminho à reforma do teatro português por Garrett, e ao aparecimento de um repertório dramático nacional, inspirado na teoria do drama romântico. Pela mesma época, também, inicia-se a publicação da primeira revista romântica portuguesa O Panorama (1837). [...] É à roda de 1840 que se situa o apogeu do primeiro Romantismo português: pouco antes ou um pouco depois publicam-se o Alfageme de Santarém; Um Auto de Gil Vicente; Eurico; a maior parte das 
Lendas e Narrativas; O Monge de Cister, O Frei Luís de Souza etc. (p.719)

É, portanto, somente a partir de 1836 que a produção literária romântica se intensifica. Nas três primeiras décadas em Portugal, o desenvolvimento literário é praticamente nulo por várias causas: (i) o isolamento do país; (ii) o prestígio dos clássicos consolidados; (iii) a resistência à abertura de uma nova estética; (iv) além de que "todas as atenções, todos os cuidados estavam aplicados às misérias públicas e aos meios de as remediar" (HERCULANO, 1986, p.18). Essa retenção contribuiu para o propósito romântico de retorno às origens.

José Augusto de França (1972) ressalta que, no país, a maioria da população era de analfabetos, ligada às práticas agrícolas nos meios rurais, constituída por pequenos proprietários, rendeiros e escravos que viviam em situação miserável. Na cidade, porém, estavam situados os pequenos núcleos industriais e burgueses (p. 162), onde se achava o público romântico, enraizado em vivências locais e regionais: a terra, a rua, a paisagem local, o lar burguês e os objetos familiares [...] (LOPES \& SARAIVA, 1972, p. 685).

Em Portugal, os grupos de intelectuais e políticos tinham interesse pela instrução, intrinsecamente, ligados ao desejo de imitar a França e a Inglaterra, que se encontravam em plena revolução econômica, política, social e cultural. Nem o fato de Portugal pertencer a um número de nações, com um espaço colonial potencialmente rico, reequilibrava sua imagem medíocre e de pouca valia entre as nações europeias. Como resumiu Oliveira Marques, 
"Portugal foi um país controlado e condicionado pelas grandes potências europeias" (2002, p.282).

Eduardo Lourenço delineia uma visão de Portugal dos oitocentos, dividida em duas versões: a do fascínio e a do ressentimento. Afirma que há uma consciência da distância e da marginalidade cultural diante da Europa. Considera, também, que a Europa distinguia-se não apenas pela maneira particular de "ser cultura, mas na invenção da atitude e da realidade da cultura como domínio autônomo, pois se opuseram conscientes, sobretudo, pelo pensamento" (1994, p.158). (aumentar a citação- v. tb o original)

Essa consciência dos atrasos concretos em relação à Europa, reforça a vontade de transformação cultural de Portugal em torno de uma burguesia empreendedora, da reforma religiosa, da busca de especialização científica e do desenvolvimento econômico.

Com o desejo de progresso, os grupos de intelectuais defendiam a instrução popular, embora cada um assumisse uma postura distinta. Para Boto,

Liberais reivindicavam esse direito, até para justificar perante o povo o que seria - digamos assim - a ordem natural das coisas. Democratas reivindicavam-na para expandir os direitos sociais. Socialistas reivindicavam-na como possibilidade plena para tornar consciente o sonho de emancipação. (1997, p.25)

Fernandez (1978) destaca que, com a revolta liberal de 1820, o aspecto pedagógico mais saliente que se poderá assinalar é a criação, em 
1817, de escolas elementares (p.96). Isso porque entre os múltiplos temas evidenciados na cultura portuguesa daquele momento - o sentido europeu, a visão da pátria, a sabedoria jurídica, doutrinas e preocupações pedagógicas morais - o tema da educação ocupava lugar central.

A difusão das literaturas, de matriz francesa e da Europa em geral, que caracteriza os oitocentos, eram fontes primárias da intelectualidade oitocentista Portuguesa. A abertura à sedução do estrangeiro, enquanto produtor de ideias e modelos capazes de inovarem uma estética clássica e neo-clássica, apresenta-se como realidade reconhecida em Portugal. A título de exemplo, está a quantidade de obras inglesa e germânica, lidas em francês. Este código linguístico constituiu-se como veículo privilegiado no país. A ele se tem oposto algumas tendências nacionalizantes e autonomistas provocadas pela consciência de uma unilateralidade de consumo (OUTERINHO, In: MACHADO, 2003, p.01)

\subsubsection{Representantes Do Estado Português: Os Intelectuais Dos OITOCENTOS}

Os escritores românticos lusos são, como salienta António José Saraiva, os intérpretes dos ideais revolucionários e consideram a revolução literária como um dos aspectos da revolução social (1972, p.157), o que, em 
síntese, caracteriza, em terras lusitanas, o movimento romântico ao adaptar-se às condições culturais do país.

Daí o fato de os intelectuais românticos, autoencarados como mediadores por excelência entre Estado e sociedade, empenhados na busca de soluções para o problema do redesenho da vida nacional, demonstrarem a urgência de renovação das estruturas e mentalidades de um Portugal retrógado e decrépito. À sombra da Revolução Industrial (1760), como diz Álvaro Cardoso Gomes, “(...) nessa Europa que começa a viver aceleradamente o futuro, há um país que parece ancorado ao passado. É Portugal. Sem o fulgor, o brilho de Londres e Paris, Lisboa, sua capital, adormece às margens do rio Tejo" (In: MACHADO, 2003, p.329).

A pátria lusíada, para vencer o sistema absolutista, passa por uma sangrenta guerra civil que a deixa num estado de exaustão, despovoamento e empobrecimento, que somente uma tomada de medidas drásticas tem o poder de reerguê-la, de fazê-la recuperar a prosperidade econômica do início do século, de promover, enfim, a sua regeneração.

Entre as aludidas medidas, na condição de redenção do atraso nacional, é que se destaca a reforma da educação, desde a base até o ensino universitário: Instrução geral elementar; instrução geral superior: "eis os fundamentos da futura felicidade do país, da felicidade do estado e dos indivíduos" (BUESCO,1997, p.264). Transferida das mãos da lgreja para as do Governo, a atividade educacional torna-se livre e pública, constituindo o núcleo da cultura laica moderna. Assim, os luminares do romantismo luso, estimulados pelo ideário liberal, vão impulsionar os escritores a trabalharem intensamente, 
para construir as novas tradições e instituições de que o novo regime necessitava. Nos trinta anos que se seguem à guerra, assiste-se ao esforço de criação de uma cultura liberal: reescreve-se a história da nação; reorganizamse os arquivos e bibliotecas; criam-se novos instrumentos de produção e divulgação cultural; reforma-se o ensino básico e cria-se o ensino técnico; e desenvolve-se uma série de publicações periódicas destinadas à instrução do novo público burguês (MACHADO, 2003, p. 12). São numerosos os escritores do romantismo que tomam parte nas lutas doutrinárias e até desempenham um papel ativo nas lutas civis: eles se colocam quase sempre do lado da liberdade e do progresso social.

Escritores como Almeida Garrett, Herculano Julio Dinis, Antonio Feliciano de Castilho, João de Deus, Camilo Castelo Branco, entre outros, na vida e na literatura de seu país, demonstram uma grande força renovadora e civilizadora: ensinam os seus compatriotas a ler e ensinam o que devem ler. Como sublinha Sandra Vasconcelos:

[...] se para a aristocracia o "gosto" não precisava ser criado, pois era considerado parte integrante de sua herança cultural, para a classe social que começava a emergir das importantes mudanças sociais, políticas e econômicas que caracterizaram o século XVIII, fazia-se necessário definir e determinar a natureza de seu "gosto". (2002, p.138)

Com a vitória dos liberais em Portugal, no ano de 1834, Garrett, iniciando uma carreira de burocrata na organização jurídica e administrativa do novo Estado Liberal, é nomeado secretário de uma comissão encarregada de 
propor um plano geral de educação e ensino público. E é dentro de seu magistério nacionalista que ele, no tratado "Da Educação" (1829), se expressa:

Eu tenho que nenhuma educação pode ser boa se não for eminentemente nacional. Nem o próprio "cidadão de Genebra" era capaz de educar bem um cidadão estrangeiro. Devemos examinar as escolas, estudar os sistemas de educação dos países mais civilizados, não para mandar a elas nossos filhos - que os não queremos para franceses, ingleses, ou alemães, senão para portugueses -, mas para melhorarmos e aperfeiçoarmos nossas escolas por essas. (1966, p. 677).

A educação para o grupo de intelectuais liberais não se restringia à alfabetização e à formação profissional, sendo necessária, também, uma preparação para as coisas do espírito, para apreciação do belo, pois só assim, a nação pode se elevar e atingir o estágio de civilização moderna. Assim, o homem de letras, numa nação de analfabetos como a de Portugal deve atuar na reforma, na sua reabilitação, na sua atualização, através do esclarecimento da sociedade pelas artes, particularmente pela literatura, tendo como referência a vanguarda da Europa, sem desfocar a índole e as tradições lusitanas.

Ofélia Paiva Monteiro observa que naquela a altura, o

[...] homem de cultura, entre tantas causas que defendeu, instituiu e organizou o ensino artístico, lutou pela democratização da cultura, pela valorização das fontes de nossa identidade e das formas populares de cultura, pela 
defesa do património e dos direitos da propriedade literária, pela independência dos intelectuais. (In: MACHADO, 2003, p 20)

Saraiva reconhece a educação do leitorado como uma das funções primeiras da arte no ideário do romantismo, haja vista a "consciência por parte do escritor de uma verdade ideológica de que ele deve fazer-se intérprete.[...] um novo tipo de relações entre o escritor e o público" (1972, p.688). Ofélia Paiva Monteiro ressalta que escritores como Garrett invocam "cidadãos ilustrados que contribuíssem para a energia da Nação, largo estrato onde a burguesia [...] assumia o papel de classe motriz" (2003, p.26).

Para viabilizar as ideias reformistas, o grupo de escritores põe-se no terreno da educação estética e dedica-se à criação de uma 'élite' cultural, por meio da abertura de conservatórios musicais, academias de letras e de arte, bibliotecas e teatros. Como nota Alberto Ferreira: "Se bem que por formação e tendência natural fosse um literato, [Garrett] compreendeu a importância da conexão histórica entre arte e sociedade" (1971, p.53).

Nessa atitude, os escritores imbuídos do sentimento do dever cívico e na busca dos processos necessários para captar o seu público, através do teatro, dos romances e livros de poesia, jornais e revistas, conduzem o propósito maior do romantismo português: "educar-lhe o gosto (...), despertá-lo para o renascimento nacional (BRAGA, s.d., p. 179). Mergulham em épocas gloriosas do país, em busca de exemplos e modelos para instruir o público que se forma na esteira das ações liberais, para ensinar o presente, sendo Herculano, de acordo com Braga,"o principal educador da classe média em Portugal e o agente que mais despertou o sentimento patriótico" (p. 217). 
Os modelos e criações que os escritores procuram espelhar para a Nação portuguesa encontram-se, de forma multifacetada, na condição de profissionais envolvidos em cargos políticos, nos estudos de culturas literárias estrangeiras, como o alemão, o inglês e o francês, em leituras das obras originais de Herder, Schiller, Goethe, Victor Hugo, entre outros (SARAIVA, 1972, p.83).

Verificam-se propostas voltadas para a reconstituição do passado mítico-lendário da nação lusitana, o que configura uma forma de trazer o passado do país para o presente. Muitos são os poetas e ficcionistas, como Alexandre Herculano, que vão beber nas fontes originais de seu povo, nas tradições mais antigas de sua língua e religião. Como função educativa e formativa, a literatura e a história encontram-se numa perfeita sintonia com o ideário romântico, pois o romantismo, como diz Alberto Ferreira: "mais parece um facto social, paidêutico, formativo e filosófico, do que um facto exclusivamente artístico" (1971, p.36).

Sandra Vasconcelos assinala que o desejo de educar o leitor, de influir na sua formação, de oferecer-Ihe instrução de maneira agradável, e até mesmo imperceptível, mostra claramente a construção de um elo entre o escritor e seu público (2002, p.103). Em verdade, a literatura é investida de uma função estética, de uma função educativa, de uma função mística, meio de regeneração da alma, e de um veículo de exaltação da fé cristã. Como salienta Alberto Ferreira: 
[o Romantismo] defende o ensino popular de composição burguesa (conjunto de noções para o aprendizado das primeiras letras e para a formação de conhecimentos socialmente úteis, ou seja, um ensino de cunho humanístico e prático), no intuito de tirar Portugal do último lugar em alfabetização entre os países da Europa, assim como luta pela criação de um jornalismo enciclopedista que forneça à opinião pública - aos que lêem, já se vê - os instrumentos necessários para a compreensão dos problemas artísticos, políticos e sociais. (1971, p.37)

Como se observa, numa relação pragmática, originalmente firmada pela intelectualidade interveniente, a literatura e a educação são mobilizadas, de modo decisivo, no processo articulado de construção do novo Estado Liberal. Pode-se dizer que os escritores literários românticos reconhecem, ao lado do autor e da obra, a importância do público enquanto um dos elementos constituintes do sistema literário, pois, como nos ensina Antonio Candido (1993, p.23), sem leitores não há sistema literário, mesmo se se levar em conta a existência isolada de um determinado número de autores e de textos publicados.

$\mathrm{Na}$ condição de agentes políticos, os escritores sabiam que as grandes transformações sociais e conjunturais desencadeavam, frequentemente, relevantes mudanças no universo literário. Por isso, estavam atentos ao fato de a nova espécie de audiência ser formada por um estrato relativamente "inculto" e 
[...] passa a incluir pessoas que não constituíam o receptor habitual dos livros, ou seja, pessoas mesmo iletradas, ou pouco versadas em literatura consagrada, que podiam até reunir-se em lugares coletivos para ouvir a leitura do folhetim. (POTTER e SOUZA, in: LUCAS, 1991, p.8)

Os intelectuais do Estado Português procuraram responder à tarefa do romantismo, em um primeiro momento, com uma literatura de caráter moralizador e formador e, em um outro, com uma mentalidade crítica e racionalista amadurecida.

\subsubsection{As Ações Do Estado Na Difusão Da Cultura}

No âmbito da formação de diferentes circuitos da opinião pública em Portugal, na primeira metade dos oitocentos, há necessidade de se enquadrar

o aparecimento de uma vontade cultural pelos temas científicos. Instituições, veículos e personalidades culturais tiveram um papel importante na transmissão, difusão e formação de conhecimentos e temáticas científicas e literárias. A cada Instituição correspondia uma publicação, ou seja, cada grupo de sociedade científica organizada correspondia uma publicação que veiculava, em diferentes níveis de linguagem, o que a comunidade ou grupo divulgava e 
inovava. Desse modo, estabeleciam contatos com a internacionalização dos saberes e a mundialização da Ciência, fator relevante para um país de condição científica periférica, no seu contexto europeu. Havia, pois, diferentes níveis de intervenção cultural e científica que se encontravam pulverizados por uma rede de contatos e intercâmbios.

Em solo português, as publicações periódicas em ciência somente terão oportunidade de se desenvolver, qualitativa e quantitativamente, no início do século XIX, com o liberalismo. A criação de publicações científicas seriadas mostra-se estreitamente ligada à fundação de agremiações científicas, aliadas ao desenvolvimento da imprensa e diminuição da censura estatal sobre a produção impressa.

Conforme afirma Tengarrinha (1989), em sua origem no século XVIII, a imprensa periódica portuguesa tinha caráter conservador e preocupação em agradar os leitores. Diferenciando-se da imprensa francesa, caracterizada por forte polêmica ideológica, Portugal adotou uma suposta "neutralidade" na escrita da imprensa, ainda que importando a moda publicista parisiense.

Em 1830, quando houve o restabelecimento da liberdade de associação e da garantia da liberdade de expressão, fundam-se dezenas de sociedades e proliferam-se as publicações periódicas, em múltiplas iniciativas: sociedade civil, Universidades, ação dos estudantes e de agremiações, professores, que contavam com o apoio financeiro do Estado: 
Universidade, a investigação sobre matérias de diferentes disciplinas ministradas nas Faculdades, a estudos eruditos de História e Literatura. Entre os sócios do Instituto de Coimbra muitos eram membros de famílias ilustres da região [...] No conjunto de intelectuais encontramos seis (Pinheiro Ferreira, Herculano, Andrade Corvo, Latino Coelho, Mendes Leal e Gomes Amorim) figurando como colaboradores da revista [...]. (SANTOS, 1998, p.183)

De fato, as publicações eram restritas a um público de elite, cujos objetivos visavam à função civilizadora e à difusão de conhecimentos úteis e de exemplares de literatura. Os ideólogos do liberalismo acreditavam que no alargamento da escolaridade e na divulgação cultural estaria a possibilidade de melhoria do nível de vida da população portuguesa e de sua promoção social. Explica-se, assim, a preocupação dos governantes ao colocar em prática um vasto plano de reforma educativa, que constituiria uma das bases do projeto da sociedade.

As instituições científicas que se destacaram no período do liberalismo foram:

- Sociedade Escolástico Filomática;

- Sociedade Literária Portuense;

- Sociedade Propagadora dos Conhecimentos Úteis;

- Universidade de Coimbra;

- Escola Politécnica de Lisboa;

- Escola Politécnica do Porto; e 
- Sociedade Promotora de Indústria Nacional.

Nas sociedades e associações de interesses científico e material, destacavamse os interesses políticos, históricos, agrônomos, industriais, bem como as publicações periódicas culturais e científicas, comportando as diferentes tipologias e distintos níveis de especialização e de divulgação de discursos científicos e técnicos. Além disso, deve-se levar em conta o papel dos produtores diretamente ou indiretamente ligados aos mecanismos de transmissão e difusão destas instituições e associações: as ligações com a sociedade e o protagonista de figuras de respeitabilidade e de prestígio científico na intelectualidade oitocentista portuguesa.

Importa perceber as estratégias de fluxos comunicativos montadas pelos membros da comunidade científica nos diferentes círculos da opinião publica. A legitimidade da ciência perante a sociedade e a cultura institucionalizada foi fortemente utilizada no periodismo cultural oitocentista português. Como diz Ferraz, "enquanto em Portugal se realizava uma reforma, tinha também como objetivo introduzir as ciências modernas em seus programas universitários e auferir com isso os lucros da exploração racional" (1998, p.19).

No sistema literário português, no período do Romantismo, os congressos, as conferências e as reuniões são fenômenos que demarcam a vivência coletiva. A ação individual dá lugar à participação na ação coletiva e a reflexão individual é substituída pela consulta ao grupo. Os congressos e conferências serviram para transmitir as diretrizes da instrução e da cultura aos profissionais distintos, entre eles os escritores. 
A instituição torna-se a única e legítima representante dos escritores. No seu estatuto, define o modelo de escritor: o construtor da reforma liberalista e do progresso, responsável pela apresentação da verdade sobre a grandeza da época, das ciências, da nação e pela formação do homem novo, engajado na luta pela modernização. Como um "engenheiro das almas" o escritor tem a tarefa de despertar a consciência do leitor, apresentando-Ihe os fenômenos políticos e culturais do país e da Europa, tais como a problemática da produção e a vida da Nação ante os problemas internos e externos.

$\mathrm{Na}$ Sociedade das Ciências Médicas e de Literatura do Porto, fundada em 1834 por Antonio C. de Melo, encontra-se o escritor Alexandre Herculano. Esta sociedade tinha como meta a discussão científica e a difusão de conhecimentos úteis. As iniciativas de suas ações é a criação do periódico Repositório Literário (1834-35) e d' Os Anais da Sociedade Literária Portuense (1837-41) (BUESCO, 1997, p.539).

A Sociedade Propagadora dos Conhecimentos Úteis, criada com o objetivo de disseminar os conhecimentos úteis por todos os meios de que pudesse dispor, inicia suas ações com uma publicação periódica intitulada $O$ Panorama. Tinha como acionistas representantes do Estado, como D. Maria II e a Família Real, cujas rendas mantinham uma das melhores tipografias nacionais, em que se publicou A Harpa do Crente, de A. Herculano, e Quadros da História de Portugal, de A. F. de Castilho.

A Sociedade Escolástico Filomática (1839-1846) era a associação de estudantes do ensino superior de Lisboa, que tinha como membros a geração de 1840, como Almeida Garrett e Alexandre Herculano, assim como outros da 
geração de 1850, dos quais alguns viriam a se notabilizar na vida política, acadêmica e cultural, como: Tomás de Carvalho; João de Andrade Corvo; José Magalhães Coutinho; José Maria de Andrade Ferreira; José Maria Latino Coelho; José Maria da Silva Leal Jr.; Luís Augusto Palmeirim; Sebastião Ribeiro de Sá; e Luís Augusto Rebelo da Silva, entre outros.

A Filomática serviu de modelo a um tipo de associação científica e literária e alcançou simpatia da imprensa e do público letrado. Assim, os intelectuais patrocinaram-na, reconhecendo sua importância na formação de uma elite necessária à sobrevivência da sociedade liberal. A sua vocação pedagógica apresentou-se significativa em face das dificuldades que ameaçavam a concretização da Reforma do Ensino Público de 1836.

A convivência simultânea de estudos jurídicos e humanísticos com debates sobre Ciência e Literatura favoreceu a criação de um espaço de treinamento na carreira jurídica, antecipando o exercício legislativo, bem como o alargamento de sua ação, através do periódico semanal O Cosmorama Literário.

O traço híbrido, predominante na imprensa portuguesa oitocentista, desempenha em cada período, um amplo leque de funções, seus responsáveis editoriais procuravam alcançar objetivos diversificados. O conjunto de textos produzido se singulariza pela diversidade de áreas temáticas abordadas, em espaços que vão da simples notícia ao folheto, passando pelo artigo de fundo. Manifesta-se, também, numa diversidade de posicionamentos da prática crítica, hesitante entre os ditames do gosto e o sentimento da necessidade de 
instaurar um raciocínio objetivo, relacionado com o poder da História e com o prestígio da Ciência.

Conforme Santos (1998, p.190), havia uma produção "polígrafa" que tendia a ser traço comum dos colaboradores da imprensa periódica, que trabalhava diferentes tipos de jornais e gêneros. Essa tendência "polígrafa" não seria indiferente à verificada acumulação de diferentes funções, nem ao caráter pouco diferenciado das procuras culturais num mercado limitado com condições pouco favoráveis à produção e à difusão isolada de obras, mesmo as do gênero literário em voga, como o romance ou o drama. Os jornais integravam esses produtos e captavam um número de leitores considerável. No movimento da Imprensa periódica entre a vitória liberal e a regeneração em 1851, segundo Santos, são precisamente os jornais políticos e de instruções e recreio que parecem revelar um maior poder atrativo, pelo número de tiragem, duração e títulos que atingiram.

A pesquisadora considera que a parte da imprensa de opinião e de jornais sociais e políticos, até meados do século XIX, particularizam a existência de periódicos em dois grandes grupos. Num primeiro conjunto, constituído pela totalidade das revistas e publicações literárias, englobam-se as folhas de poesia; os jornais de teatro; os magazines; os periódicos de crítica literária - ou das chamadas "revistas de livros" -; e as publicações científicoliterárias e de instituições de ensino superior. Num segundo conjunto, o grupo dos periódicos culturais, com os jornais de instrução e recreio; os semanários pitorescos; as revistas ilustradas destinadas à divulgação de "conhecimentos úteis"; e as publicações galantes ao público feminino. 
Dentre os jornais de poesia, predominavam as publicações organizadas e editadas por grupos de poetas, sociedades acadêmicas ou grupos de agremiações culturais, que Ihes serviam de suporte financeiro. Destinavam-se a promover o lançamento de jovens estreantes universitários que, neles, divulgavam as primeiras tentativas poéticas, como o caso das revistas de Coimbra O Trovador (1848) e O Novo Trovador (1851-1856) (FRANÇA, 1993, p. 317-28). Em Lisboa, há registro de iniciativas semelhantes, como o já referido Cosmorama Literário (1840).

Exterior aos meios estudantis, a criação periódica do mesmo tipo servia de porta-voz a determinados grupos intelectuais e às novas gerações de poetas, como A Lira da Mocidade (1848-1850), Miscelânea Poética (18511852), e A Grinalda (1855-1869) (MACHADO, 2003, p.270-78). Nesse período proliferaram as folhas de poesia editadas pelos círculos ultra-românticos do Porto.

Os jornais de teatro desempenharam uma função divulgadora, servindo de instrumento aos empresários teatrais que os financiavam e lançavam com o objetivo de promover a atividade dramática e informar as atualidades do mundo do espetáculo. Havia também revistas de crítica de teatro, de ópera, e textos dramáticos nacionais e estrangeiros, publicados na íntegra ou na forma de folhetim. Estas se destinavam a um público dos meios literários e frequentadores de teatros (MACHADO, 2003, p.183-4).

A "revista de livros" em Portugal e os magazines de maior qualidade literária destinavam-se a setores restritos do público leitor, constituídos pelas elites social e acadêmica. A escassez de um público culturalmente preparado 
para apreciá-las impedia as vendas e tiragens significativas, que garantissem a sua sobrevivência. Esses fatores explicam a carência de publicações desse gênero no mercado da imprensa oitocentista. As publicações mais elitistas substituíram as publicações deste gênero, tais como $O$ Jornal do Conservatório (1836-1849) e os Anais da Academia Real das Ciências (1857).

As revistas literárias tinham matérias dedicadas a ensaios de temáticas diversas da História, Filosofia, Ciências Sociais e as Belas-Artes, mas não concorriam com as revistas de instrução e recreio em franca expansão. Segundo Silva (2001, p. 94), a explicação dessa rejeição por determinados grupos de trabalhadores reside no grau de complexidade dos artigos e na ausência de gravuras. Exemplo é a Revista Estrangeira, organizada em três seções distintas - Literatura, Ciências e Artes e Miscelâneas -, que tinha como modelo publicações como a Revue dês Deux Mondes e a Revue Britannique, e que pretendia divulgar textos lançados em literaturas estrangeiras francesas e britânicas, funcionando como "uma revista das revistas" (MACHADO, 2003, p.145-46) Foi substituída pela Revista Literária do Porto, de alta qualidade, elogiada por Herculano, que anteriormente denunciava a "acidez e o caracter desinteressante da 'Revista Estrangeira'”(SANTOS, 1998, p. 183).

Havia ainda as revistas especializadas, fundadas por associações ligadas ao exercício de profissões liberais ou intelectuais. As publicações em causa, como os Anais Marítimos e Coloniais (1840-1846) e o Repositório Literário, com títulos de memórias, anais, atas ou boletins, destinavam-se a servir de órgãos divulgadores das referidas instituições, neles procedendo-se ao registro das suas atividades e iniciativas. Esses periódicos constituíam um 
forum aberto à participação dos associados que publicavam regularmente seus textos.

As agremiações e sociedades literárias e científicas, constituídas à margem de interesses profissionais e acadêmicos, são iniciativas de grupos de pessoas empenhadas na divulgação científica e no progresso, como o Jornal da Sociedade dos Amigos das Letras de Lisboa (1836) e O Pantólogo (18441846) de responsabilidade da Academia das Ciências e Letras (SANTOS, 1998, p.183).

Serrão (1986, p.312-16) observa os esforços empreendidos por Mourinho de Albuquerque e Passos Manuel, para instituir as bases do sistema escolar primário e secundário, com o intuito de suprimir as graves deficiências do público leitor português. Havia, no entanto, outros fatores a considerar: elevado preço dos livros; escassez do mercado; a inexistência de um número significativo de bibliotecas públicas; e o aspecto desinteressante dos periódicos publicados.

A Imprensa no romantismo português viria como instrumento essencial à transformação da sociedade. Desempenharia, assim, um papel fundamental no vasto programa de reforma educativa que o novo regime pretendia colocar em prática, promovendo a democratização do saber e o alargamento da instrução a extensas camadas da população portuguesa, habitualmente condenadas a permanecer num estado de profunda ignorância e gritante subdesenvolvimento cultural. Da ótica da intelectualidade portuguesa dos oitocentos, a imprensa tinha por missão desempenhar uma tarefa civilizadora, contribuindo para a reforma dos costumes e das mentalidades e 
assumindo o papel educativo, através da difusão dos conhecimentos úteis e da expansão do gosto pela leitura. Assim, explica-se que, com a enorme profusão de textos doutrinais e literários - incluindo as narrativas folhetinescas diversas, romance, conto e poesia -, ocorresse a publicação de textos de caráter heterogêneo, tais como os de curiosidades e estatísticas, acontecimentos sociais e culturais, anedotas, advinhas, charadas ou questões algébricas.

Os tipos pitorescos, como O Panorama, Ilustração, O Ramalhete, 0 Museu Portuense, O Arquivo Pitoresco, com gravuras e ilustrações de vistas das cidades estrangeiras e de movimentos famosos, retratos de personalidades históricas, divulgavam os avanços científicos e tecnológicos. 0 perfil diversificado e a natureza enciclopédica dessas publicações constituíam dois dos principais eixos da estratégia editorial adotada: facilitar os conteúdos e lançar revistas com artigos de boa qualidade a diversos leitores trabalhadores e burgueses ávidos de saber e o público culto. Garantia um número de leitores elevado, diversificado e manteria as tiragens assegurando a sobrevivência dos periódicos. A esse respeito Tengarrinha observa:

A questão relaciona-se, igualmente, com a ascensão econômica e social da burguesia comercial. Abrindo-se-lhe cada vez mais de par em par as portas dos salões aristocráticos ou aristocratizantes, reconhecendo, por outro lado, a necessidade de alargar a visão dos problemas com maior bagagem de conhecimentos práticos e teóricos, a burguesia ligada aos negócios precisava de adquirir rapidamente uma vasta cultura. Não uma cultura, como da aristocracia, vazada aos pesados e austeros moldes clássicos, mas leve, variada, servindo às necessidades imediatas da vida, tanto no domínio econômico como social. Nada melhor, 
para isso, do que jornais enciclopédicos, que ministravam, "em pequenas doses", conhecimentos gerais de literatura, artes, história, a par de conselhos sobre a melhor maneira de preparar e conservar os couros, "modos de destruir as pulgas, percevejos, etc", processo mais seguro de embalar artigos. (1989, p.51)

A respeito da função pragmático-pedagógica dos periódicos literários, na fase inicial do romantismo luso, Túlio Ramires Ferro, no artigo "O Problema da Educação na Literatura Portuguesa do Século XIX", frisa que:

[...] é essa crença fervorosa na regeneração operada pela educação que vai dar uma estrutura inconfundível a numerosas revistas literárias publicadas na primeira metade do século XIX; leva escritores prestigiosos (Garrett, Herculano, Castilho) a dissertarem sobre a educação e eles próprios subordinam toda a sua produção literária a uma elevada missão cívica de pedagogia literária e social, reconhecida e louvada pelos seus contemporâneos, que os consideram como mestres que Ihes inculcam lições exemplares (1994, p. 639).

As estratégias governamentais e da sociedade civil dos oitocentos tiveram consequências imediatas no sistema literário português: o fervilhar de publicações periódicas, a multiplicação dos círculos literários, a difusão da cultura nacional e a absorção da cultura europeia em voga. 
2

\section{O LUGAR Do Romance O Escravo}

\section{No RomantISMO PoRTUgUÊS}


O romance assimilou diversos

gêneros literários desde o ensaio e as

memórias até à crônica de viagens; incorporou múltiplos registros literários, revelando-se apto quer para a representação da vida cotidiana, quer para a criação de uma atmosfera poética, quer para a análise de uma ideologia. Aguiar e Silva, Teoria da Literatura, 1972.

Este capítulo dedica-se ao romance no pleno período romântico, procurando identificar suas vertentes e temas, recorrentes no período que vai de seu surgimento até a década de 1860.

\subsection{As Formas Do Romance}

O gênero romance, como produto criado no romantismo, tinha em Portugal, além da função de fruição, o compromisso ante sua época e as ideias que o motivaram. O escritor "já aureolado de admiração, ganha uma nova consciência do seu papel relativamente às massas" (SARAIVA, 1972, p.154), ao perceber que, no ideário da estética romântica nacional, exerce a função de instrutor informal do público leitor. 
Márcia Abreu, em seu estudo sobre as trajetórias percorridas pelo gênero romance, observa que até o momento de sua consagração nos finais do século XIX, um dos quesitos convencionais mais presentes "na avaliação da qualidade de um romance estava na moralidade interna à narrativa e sua capacidade de provocar comportamentos virtuosos nos leitores" (2003, p. 16). Confirma-se a argumentação de Abreu no estudo de Sobreira (1998) que procura explicar o desenvolvimento do romance em Portugal, "em duas grandes linhas", ambas visando à expansão dos leitores: de um lado, uma prática literária marcada por objetivos nacionalistas, religiosos e morais, com romances edificantes e históricos; de outro, a lógica mercadológica de sensação e efeito dos romances populares de aventuras e folhetos de cordel.

O romance funcionava como veículo para chegar a uma classe em formação, a pequena burguesia de serviços, comerciantes, empregados de escritório etc., que necessitavam de uma educação literária. O escritor ocupava-se de suas ficções para justificativas e aprovações do novo gênero, passando a disputar o interesse do público leitor. Um gênero que, associado ao entretenimento e à instrução dos leitores, procurava compreender as expectativas do:

[...] público potencial a que se destinavam as suas obras [...] é curioso verificar [...] a permanência de algumas constantes temáticas em todas elas. Esse cuidado posto na escolha dos temas que mais o atraíam e simultaneamente atraíam o público constitui, segundo o mesmo autor, a razão do seu extraordinário êxito, que não se desenvolveu apenas em extensão, mas também em profundidade. (NABAIS, 1998, p.1213) 
O romance, enquanto gênero, mostra-se flexível. Pensa-se a si mesmo nos prefácios e nas críticas, populariza-se por meio do folhetim, cria um público, uma indústria cultural e oferece uma nova imagem do escritor, que se consagra, serve à construção de um ideário nacionalista (ABREU, 2003, p. 16). No interior da narrativa romanesca, discutiam-se questões sociais como, o papel da Igreja, do Papa e dos padres, o poder dos monarcas e o direito dos povos, entre outros temas.

O romance quebra fronteiras, recusa padrões fixos, possui caráter inclusivo e capacidade de abarcar e assimilar traços de outros tipos de escrita, de integrar outras formas, absorver estratégias (VASCONCELOS, 2003, p. 4). Esses fatores facilitam a escrita, o enriquecimento do romance e a conquista de seu público. O romance Eurico, o Presbítero, de Herculano, por exemplo, arquitetado como um poema em prosa, apresenta, pela cadência, sugestão e sonoridade, características quase versificatórias em certas passagens, o que converge para a imensa irradiação da obra e para o poder de penetração de seu autor junto às massas. Conforme Carlos Reis:

[...] projecção sociocultural de que o romance beneficiou na época em que foi publicado e mesmo depois dela; trata-se de um aspecto relevante, sobretudo se tivermos em conta que o timbre dessa recepção tem muito que ver com a evolução do gosto romântico em Portugal e com o desenvolvimento da literatura ultra-romântica. (1994, p. 24-5) 
Assim, o romance português tornou-se um lugar de experiência e misturas de gêneros: filosófico, sentimental, moralizante, pedagógico, subjetivo, entre outros. Desse modo, a criação ficcional em prosa conquista respeitabilidade social, cidadania literária, recebendo não só a consideração do escritor, mas também o interesse dos letrados e a admiração do público leitor. Faz-se necessário lembrar que o público romântico está enraizado em vivências locais e regionais: a terra, a rua, a paisagem local, o lar burguês, os objetos familiares, que já se revelam na pintura holandesa do século XVII (LOPES e SARAIVA, 1972, p. 685). É ao gosto do novo público que se deve atribuir o desenvolvimento, a partir de meados do século XVIII, do gênero literário mais característico da Idade Contemporânea: o romance de ambiente burguês ou plebeu, em que se condensa, na forma de ficção, uma análise de caracteres, ambientes e problemas, com sua tendência inicial acentuadamente sentimental e moralista.

Para Buescu, o sentimento nacional exprime o pensamento de que a Nação e o povo não são senão versões coletivas do "individual" (1994, p. 72), ampliando a noção de individualismo. Acredita, portanto, que a história pessoal do sujeito reflete intimamente a história da Nação, conforme expõe Wolfgang Kayser:

Até quando o assunto - como, por exemplo, em muitos romances históricos - é um grande acontecimento, que abrange povos inteiros, nesta direcção se tratará sempre de vivências pessoais: o tempo das cruzadas chama-se Ivanhoé (1819), a derrocada do domínio dos Visigodos é Eurico, o Presbítero. (1979, p. 17) 
Conforme Antonio José Saraiva, o individualismo ou subjetivismo romântico português estava ligado a uma "reação às formas novas de envilecimento humano, e até paisagísticos, acarretadas pela onipotência do dinheiro, agora sem entraves às suas funções capitalistas e pela revolução industrial da máquina a vapor alimentada a carvão" (1972, p. 727). O crítico coloca a valorização do eu, tema recorrente do Romantismo, como medida crítica à desumanização, gerada e alimentada pelo capitalismo industrial.

A realidade histórica vivida nos romances portugueses é recriada por novos horizontes políticos, que ora se apresentam cheios de problemas e causadores de novos males sociais, e ora como lugares privilegiados para as utopias sociais. O romantismo afirma-se como elemento de revolta relacionado a um sentimento de frustração diante do progresso material e econômico, promovido pelos avanços industriais, subdividindo-se numa "primeira fase, nacionalista e histórico e mais tarde, também regionalista e passional" (BUESCU, 1994, p.484).

O romance histórico, criação do romantismo, abriu novos caminhos para os escritores em Portugal. Teve sua origem na Inglaterra com Walter Scott, brotando da observação da realidade com o intuito de oferecer ao leitor uma imagem de sua própria realidade: um testemunho do passado com a capacidade de iluminar o presente e o futuro. Em Portugal surge em 1836, $A$ Voz do Profeta, de Alexandre Herculano e logo "aparecem as primeiras traduções de Walter Scott e, em que Os Ciúmes do Bardo e Noite do Castelo, de Castilho, denunciam o triunfo entre nós do novo gosto literário" (SARAIVA E LOPES, 1972, p.719). 
Em 1843, publica-se n’O Panorama, O Pároco de Aldeia, de Alexandre Herculano, e na Revista Universal Lisbonense, a obra Viagens na Minha Terra, de Almeida Garrett. As narrativas conduzem à educação do gosto e, lentamente, o público se afeiçoa ao gênero de atualidade. Conforme J. Gaspar Simões, essas obras representam, na primeira metade do século XIX, "o novo na nossa novelística, toda ela, por então, consagrada ao romance histórico" (1987, p. 301).

O romance histórico apresenta elementos do mundo épico e bárbaro da Idade Média em contraste aos do mundo prosaicamente moderno. Verificam-se, assim, traços da narrativa cervantina, com a cultura cavaleiresca e com características, tais como: heroicidade e sentimento de honra.

Há dois modelos de romance histórico: o de Alexandre Herculano, com O Bobo, de 1843, e Eurico, o Presbítero, de 1844; e o de Almeida Garrett, com O Arco de Sant'Ana, de 1845, nos moldes de Victor Hugo. O primeiro escritor tem o compromisso com o retorno ao passado para compensar a decadência presente, "uma espécie de sacerdócio", como escreve na Introdução de $O$ Bobo. Herculano projeta em Eurico, o Presbítero um semideus, capaz de libertar a Península Ibérica do jugo mouro durante a Idade Média, legando um símbolo de patriotismo e grandeza que pudesse servir ao presente como parâmetro na empreitada regenerativa. Garrett volta-se a um romance com herói revoltado contra o pai, em nome da justiça e do amor; com um narrador que quer construir e atar as pontas da história narrada e do próprio fazer da história ficcional; misturando gêneros e registros discursivos, tais como: lírico-descritivo, narrativo-descritivo, reflexivo, dramático, na elaboração de um romance inovador. 
Garrett e Herculano respondem à questão da construção do sujeito português, de concepção nacionalista, pois enquadram o passado português em contornos heróicos, épicos, na forma de personagens colocadas para alegorizar e afirmar a Pátria, tomadas como representantes do povo português. Note-se que em Portugal o romance histórico não resulta de um desvio de uma corrente romanesca antecedente, em franca oposição com o que ocorrera décadas antes na Inglaterra, onde Walter Scott, precursor desse subgênero, fora precedido por Defoe, Sterne e Fielding, que já haviam explorado a forma do romance em escalas mais abrangentes, legando uma tradição (SIMÕES,1969, p.12).

Vítor Manuel de Aguiar e Silva, ao tratar do romance em Portugal, afirma:

[...] o romance e a novela tinham iniciado entre nós a sua aproximação da realidade contemporânea antes de meados do século, desenvolvendo as sugestões contidas no "Pároco de Aldeia" e nas Viagens na Minha Terra e aceitando a lição de Balzac, George Sand e Eugène Sue. (...) O exemplo desta literatura de ficção que procurava na actualidade as suas personagens e se debruçava já, embora timidamente, sobre certos problemas sociais, não deixou também certamente de orientar o teatro português na busca de uma temática actual. (1973, p. 132-33)

Nos caminhos de Garrett e Herculano seguia uma série de escritores: 
- Oliveira Marreca - O Conde de Castela (1844);

- Rebelo da Silva - Rausso por Homizio (1842) e Ódio Velho não Cansa (1848);

- Arnaldo Gama - Um Motim há Cem Anos (1861), O Segredo do Abade (1864) e O Filho do Baldaia (1866);

- Andrade Corvo - Um Ano na Corte (1850);

- Camilo Castelo Branco - Luta de Gigantes (1865) e O Judeu (1866);

- Coelho lousada - A Rua Escura (1857);

- Oliveira Martins - Febo Muniz ( 1867);

- José da Silva Mendes LeAL - Os Irmãos Carvajal e Os que foram portugueses;

- Bernardino Pereira Pinheiro - Estréias literárias, El-Rei, Perdoa, Luz e sombras (1863) e Amores de um Visionário (SIMÕES, 1987, p. 45-66).

\subsection{TEMAS RECORRENTES E LATERALIDADE NO ROMANCE PORTUGUÊS}

Nesse subgênero romanesco, a temática da religiosidade e as crises da alma são recorrentes: "O tema, aliás, vinha de longe, na literatura inglesa, até o "Parson Adams", de Fielding, e o "Tio Toby", de Sterne, e Walter Scott tão lido por Herculano" (NEMÉSIO, 1969, p.8). Corresponde à esfera de uma 
literatura séria e civilizatória, que tem a preocupação da literatura enquanto "programa educativo" para um leitor que precisava de orientação "numa sociedade cada vez mais corroída pelo materialismo, pelo egoísmo e pela indiferença religiosa, o homem das letras se [sinta] no dever de desempenhar um papel de consciência axiológica" (SOBREIRA, 1998, p. 206).

Nesse sentido, tem-se uma concepção pedagógica da literatura, com uma visão moralizadora diferente da concepção do historiador, pois este revela a realidade como ela foi ou é; aquele se obriga a apresentar uma imagem positiva do bem, com virtudes recompensadas e punições aos malfeitores.

Esse tipo de romance tem a pretensão de oferecer ao leitor um enredo de virtudes, justiça e razão, em que o belo e o bem estão associados e integrados na literatura como utilidade e edificação. Ademais, a realidade social não é apenas um reflexo da natureza celestial: a burguesia, representada nesses romances encontra-se ávida de conhecimento, de enriquecimento cultural, realizando leituras sobre religião, história, filosofia, música. Assim, heroínas e heróis com caráter e virtudes aprendem e não se saciam nunca.

O escritor Júlio Dinis é modelo de romancista pedagogo, acompanhando o projeto educativo da primeira geração romântica. Seus livros são instrumentos educativos, civilizatórios e doutrinais para as massas, voltados para a sadia moral do campo. Elabora uma perspectiva teórica para a sua criação ficcional, conforme registram seus manuscritos esparsos, que levaram João Gaspar Simões a considerá-lo o primeiro teorizador do romance em Portugal (1969, p. 151). Os seus romances apresentam temática rural, através do desprezo à cidade e do elogio à aldeia. Apenas o romance Uma 
Família Inglesa (1868) não participa da formulação dos romances campestres de Júlio Dinis.

António José Saraiva e Óscar Lopes (1972) estabelecem um diferencial entre a temática campesina na produção de Camilo Castelo Branco e Julio Dinis. Para os críticos, em Dinis há um ideário purificador, um espaço mitificado; em Camilo, o campo é observado objetiva e realisticamente, pois "a observação dos tipos e da linguagem da população rural minhota torna-se mais consciente, reagindo contra a idealização por autores que tinham focado esse meio, como Júlio Dinis [...]" (p. 823).

Em História da Literatura Portuguesa, os críticos Saraiva e Lopes apontam a sedução do público pela narrativa rústica, através dos seguintes fatores:

A propriedade rural servia então claramente de base às instituições, embora a maior parte dos leitores vivesse em meio urbano. Dela partiam para a Universidade, por vezes, via seminário, adolescentes abastados ou protegidos numerosos intelectuais portugueses pertenciam a famílias de proprietários rurais, a ela estava ligada por laços mais ou menos directos quase toda a burguesia provinciana e grande parte da de Lisboa. Estas circunstâncias certamente contribuíram para a voga das características do romance rústico entre nós. Por um lado, os tipos e as pequenas intrigas de aldeia ou de vila eram mais acessíveis ao horizonte de consciência da maior parte do público português do que os problemas mais complexos da vida urbana; por outro lado, perante as condições próprias da vida urbana em desenvolvimento, da burocratização, da centralização administrativa, etc., muitos escritores reagiam idealizando um 
sucedâneo da velha tradição bucólica onde as relações humanas aparecessem menos deformantes e mais espontâneas. (1972, p. 937)

No romance português destaca-se, também, o espaço das festas e procissões, de manifestações populares, como em O Arco de Sant'Ana, de Almeida Garrett. O autor privilegia manifestações populares em meio às memórias históricas.

O tema da viagem aproxima os autores, cuja proximidade faz adotar certos procedimentos estilísticos, como o diálogo com o leitor, a fragmentação narrativa, o emprego do humor. A viagem facilitou a representação da "cor local", técnica empregada por Almeida Garrett, e reforçou a vontade de inovar o gênero novelesco.

Segundo Simões (1969), a maturidade literária do romance romântico português adotou a técnica ensaística, de caráter digressivo, fragmentário e paródico, em romances como Viagens na Minha Terra, de Almeida Garrett e O Pároco de Aldeia, de Alexandre Herculano.

As criações de entretenimento como o folheto de cordel e o romance de aventuras estariam num plano marginal do sistema literário português. Já a literatura séria, civilizadora, subdividida em romance histórico e romance moral, estava em um sistema literário canônico, pois representava as forças da tradição e da criação. Saraiva mostra que a literatura marginal se estabelece de acordo com as condições de produção, quer pelo suporte, quer pela 
natureza do texto híbrido, ou ainda pelo anonimato autorial, de distribuição e de consumo, destinados às camadas menos instruídas da população portuguesa.

O romance popular oitocentista causou reações imensas ao público que se deliciava com as histórias de acontecimentos distantes do cotidiano miserável vivido, em oposição aos intelectuais que os condenava em nome da pureza da arte e da honestidade dos costumes.

Em contrapartida, a epopeia burguesa, lançada no comércio e sujeita às suas leis, ou seja, passível de ser aceita ou rejeitada como qualquer outro artigo posto à venda, como um objeto produzido e colocado em circulação num contexto capitalista, entra definitivamente no jogo do mercado. O público burguês firma-se como uma peça fundamental no processo de produção e consumo do romance, principalmente, o leitor feminino. Nesse particular, observa-se a presença constante da figura do leitor na narrativa garrettiana Viagens na Minha Terra.

Carlos Reis destaca que:

[...] leitora por vezes é a que está em causa; sintomaticamente as alusões à leitora ocorrem sobretudo quando se processa 0 relato da novela (da menina dos rouxinóis, inserida na narrativa das Viagens), susceptível de ser apreendida como história marcada por traços de romanesco e sentimentalidade que justamente (e logo de início) o narrador se apressa a esbater (...). E em diversas outras circunstâncias (por exemplo, quando se trata de descrever (...) a personagem sedutora que é Carlos, quando se comenta o seu "romantismo vago, descabelado, vaporoso e nebuloso"), é ainda a atenção da leitora que expressamente o narrador 
supõe activada, reconhecendo-lhe esse perfil romântico cujos excessos devem ser corrigidos. (1998, p. 42)

Destaca-se outro subgênero romanesco que ganha prestígio: é o romance passional Amor de Perdição (1862), de Camilo Castelo Branco. Considerada uma novela de paixão amorosa intensa e profunda, teve reconhecimento da crítica e se transformou numa narrativa de sucesso. A narrativa de atualidade, sentimental, passional, satírica, de costume mostra-se no romance Onde Está a Felicidade? de Camilo Castelo Branco, o maior sucesso do escritor e que "é ainda um dos livros mais lidos do país" (BUESCU, 1994, p.81).

De acordo com Alberto Ferreira (1979, p. 66), os escritores do ultraromantismo em Portugal, elegem Camilo como seu mestre. Buescu nota que:

[...] o ultra-romantismo coincidiu [...], cronologicamente com o romantismo formulado pela Primeira Geração. O próprio Almeida Garrett, aliás, classificara já criticamente de "Plusquam românticas" certas composições, segundo os seus próprios termos, de "solta e descabelada liberdade. (1994, p. 79)

Conforme Simões (1969), o romance campesino foi criado entre o romance histórico romântico e o romance realista oitocentista. Concentra-se no progresso urbano, focaliza o tédio, a opressão da cidade, ao mesmo tempo em que enfoca o saudosismo da vida primitiva das aldeias e dos vilarejos portugueses, com seus valores pré-industriais. Introduz-se o realismo rústico 
em Portugal com os romances: Viagens na Minha Terra, de Garrett e O Pároco de Aldeia, de Alexandre Herculano.

Sobreira destaca o romance A Mão do Finado, de Alfredo Possolo Hogan, como exemplo do romance popular que aborda os problemas sociais, critica a exploração das classes pobres e o enriquecimento ilícito da burguesia (p. 209). Seu projeto, assim como de outros autores do romance popular, objetiva as necessidades de evasão e de entretimento das massas leitoras, além dos princípios humanitários e sociais.

Um exemplo de obra folhetinesca é Maria! Não me Mates, de Camilo Castelo Branco "que representa ao vivo o falar do povo, mesmo se isso não correspondeu tanto a uma opção sua como uma imposição do "gênero"' (SOBREIRA, 1998, p.191). Esse tipo de romance não pretendia se aliar a nenhuma ideologia política ou religiosa, pois o ideal era de liberdade artística, a preocupação com as solicitações do público leitor, bem como a busca de autonomia literária. Sobreira, em seu estudo sobre os best-sellers de Portugal das décadas de 1840 a 1860, apresenta os romances $A$ Virgem da Polônia, de José Joaquim Rodrigues de Bastos, e Eurico, o Presbítero, de Alexandre Herculano, enquadrados "no sub-campo da arte pura (entendida aqui como a arte moral, útil e civilizatória) onde representam, respectivamente, a 'literatura consagrada' e a 'literatura de vanguarda"' (1998, p. 8).

A obra Eurico, o Presbítero é um romance de tese que recria a solidão da alma a que a lgreja condenou os seus ministros e a mulher angelical, todavia, o tratamento do problema ético-religioso do celibato e da pureza feminina apresenta-se de forma complexa, denunciando as injustiças 
sociais; os interesses materiais que impedem o homem da realização amorosa; as agonias íntimas geradas pela luta religiosa do clero; e as tendências naturais do homem. Conforme Buescu (1994, p.126), o romance é duplamente histórico: por um lado, descreve a dissolução moral e política, por outro, relata o percurso individual de Eurico, personagem fictícia.

Nas digressões do narrador de $A$ Virgem da Polônia encontra-se a crítica à escravatura pelo predomínio da "superioridade racional e moral dos argumentos antiescravagista, [...] pelas motivações bíblicas, teológicas e 0 sentimento humanitário" (SOBREIRA, 1998, p. 69). Sobreira considera que somente com a causa abolicionista - discutida nos textos políticos da imprensa portuguesa a partir da segunda metade dos oitocentos (por medidas legislativas tendentes à abolição no Decreto de 14 de dezembro de 1854 , dispondo libertos os escravos nascidos a partir desta época, assim como os não registrados eram considerados livres) -, a escravidão passou a ser interesse temático em alguns romances e peças teatrais. Todavia, somente após o aparecimento da obra Uncle Tom's Cabbin (1851), de Harriet Beecher Stowe, traduzida em 1853, em várias versões para o português com o título $A$ Cabana do Pai Tomás, o tema passou a ser mais corrente na literatura portuguesa (GONÇALVES, 1993, p. 62, in: SOBREIRA, 1998, p. 71).

É importante destacar que a divulgação desse romance em Portugal encorajou significativo número de autores portugueses a lutarem contra a instituição escravagista, mas a atitude inicial humanitária logo se transformou em moda e banalizou-se. Sobreira especula sobre esse fato, imaginando as reações que essa posição antiescravagista teria "provocado em Angola onde o 
tráfico estava profundamente enraizado nos costumes e nos interesse econômicos" (1998, p. 72).

A imagem de Portugal era projetada nos âmbitos político e cultural, porém, a escravidão, ao menos até a metade do século XIX, foi tema lateral na escrita literária, sobre o qual os críticos fizeram silêncio. Tal afirmativa está presente na crítica de Sobreira ao referir que até 1850 a temática da escravidão, recriada na "personagem negra secundária, burlesca e desprezível" (1998, p.71) não tinha interesse para a crítica econômica da escravatura de interromper as razões escravagistas e/ou antiescravagistas. Ocupava, assim, apenas uma forma de interesse "azimute", ou seja, um ponto de direção para chegar ao real objetivo traçado: o de ordem política ou moral.

O Escravo, de José Evaristo de Almeida, publicado em Portugal em 1856, primeiro romance de temática caboverdiana, inscreve-se neste cenário de manifestações abolicionistas portuguesas, refletindo e difundindo, junto à opinião pública de Portugal e Cabo verde, uma imagem crítica em relação à escravatura que

[...] testemunha, em estilo romântico-realista, as atribulações de um amor camiliano (a escravatura do amor) condenado pelas barreiras de raça e classe e, ao mesmo tempo, a formação de uma sociedade com identidade crioula, prestes a se desembaraçar do sistema escravocrata (a escravatura de condição) e dos seus ranços racialistas (GOMES, 2008, p. 1).

António Carreira, em Cabo Verde - Formação e Extinção de uma Sociedade Escravocrata (1983), lê o romance como uma representação do 
Monteagarro, onde se preparou a malograda insurreição antiescravocrata protagonizada por um grupo de escravos que pretendia extinguir a sociedade escravocrata, assassinando os senhores brancos e tomando conta da ilha de Santiago. O crítico acrescenta que os cabeças da revolta foram denunciados, condenados e mortos. Os acontecimentos de Monteagarro são antecedidos, em 1822, pela Revolta dos Engenhos, que inicia um ciclo de revoltas.

Pondera-se, aqui, que o romance O Escravo (1856), de José Evaristo de Almeida, participa do período de desagregação da sociedade escravocrata. A ilha de Santiago é apresentada por Evaristo de Almeida como espaço de insegurança política para as elites.

Eis, em suma, um painel do romance romântico português, determinado pela configuração do sistema literário de 1830 a 1860. Foram observadas as formas do romance, as temáticas e as lógicas histórico-literárias e mercadológicas, que ditaram o lugar dos textos no centro ou na periferia (lateralidade) do sistema, no qual se situa O Escravo, de José Evaristo de Almeida. O próximo item deste capítulo trata da temática da escravidão no romance $O$ Escravo, observando-o na lateralidade do romance no sistema literário português. 
3

ESCRAVIDÃo E RaÇA No Romance O Escravo 
life is obscene with crowds of black on white death is my pulse. what might have been is not for him/or me but what could have been floods the womb until I drown

[a vida é obscena com multidões de preto sobre branco a morte é o meu pulso. o que poderia ter sido não é para ele/ou para mim mas o que podia ter sido inunda o ventre até me afogar]

Sônia Sanchez, 1987.

Branco e negros parecem complexados: o preto escravo de sua inferioridade, o branco escravo de sua superioridade.

Frantz Fanon, , 1979.

Nos diversos romances do século XIX, que tratam da escravidão no período colonial, observa-se que a, grosso modo, ora esta servirá de pano de fundo, ora será o centro da diegese na forma de denúncia. Algumas das obras idealizaram as personagens escravas, negras e mulatas, porém atribuindo-lhes traços de uma dama da corte ou da burguesia, totalmente revestida de europeidade. 
Em Pele negra e máscaras brancas, Frantz Fanon revoluciona a visão dos temas que envolvem preconceitos, como é o caso das temáticas da escravidão e da raça negra. Para o escritor, o discurso sobre o negro opera como negação da personalidade do outro, pois além da repressão individual, da exploração econômica, dos sentimentos e da consciência de si, projeta ideais do branco sobre o negro, negando a este último uma cultura própria.

A questão do posicionamento do sujeito no discurso estereotipado do colonialismo denuncia a fixação (enquanto racismo) de uma consciência do corpo que nega a si mesma: "[...] o Negro não deve mais encontrar-se colocado diante deste dilema: embranquecer ou desaparecer, mas deve poder tomar consciência de uma possibilidade de existir" (p.131).

O estereótipo do negro elaborado pelo branco impede a circulação e articulação do significante de raça, a não ser em sua fixação enquanto racismo. Fanon descreve o efeito desse processo sobre a cultura colonizada. Para ele, o sujeito marginalizado pela sua condição de raça e escravidão deve tomar consciência de si, de sua história e mobilizar-se, ampliando, assim, o sistema de referências pelo qual conseguirá reverter a destruição dos seus valores culturais.

Esse capítulo trata da questão da escravidão e da raça, no tecido do discurso do romance cabo-verdiano O Escravo. Para melhor contextualizar tal analise, vê-se, primeiramente quem for seu autor , José Evaristo de Almeida.

Pouco se sabe sobre sua biografia e obra. Nascido em Portugal no século XIX, morreu em Guiné-Bissau no século XX. Viveu tempo suficiente para participar de vários episódios históricos nas mudanças politicas e socioculturais 
que caracterizaram a vida colonial portuguesa no século XIX.

Sua obra O Escravo foi publicada em forma de livro em Lisboa em 1856. Em Cabo Verde foi publicada pela primeira vez em forma de folhetim em A Voz de Cabo Verde, Praia, do № 244 de 22/05/1916 até o oㅜ 294 de 21/05/1917 (CARRIJO, 2008, p.17). A segunda edição da obra é impressa em 1989, com tiragem de 600 exemplares, e preparada por Manuel Ferreira que em Notícia avalia o romance como "fundador da ficção caboverdiana" (ALMEIDA, 1989, p.8). Da mesma maneira o faz Manuel da Veiga no prefácio que faz a essa mesma edição:

Não há dúvidas de que a obra de José Evaristo de Almeida poderia, perfeitamente, ser escrita por um caboverdiano. Aliás, se não tivéssemos aprendido com Manuel Ferreira, que ele era português, nós, depois da leitura de $O$ Escravo, não teríamos dúvidas sobre sua caboverdianidade. Cremos que sendo ele originário de Portugal, a sua vivência, porém, era caboverdiana. (1989, p.24)

Simone Caputo Gomes escreve que a obra:

[...] se enquadra no âmbito da literatura cabo-verdiana, embora não seja escritor cabo-verdiano. Seu romance é considerado o primeiro do percurso literário crioulo, mas não sem alguns dilemas de perspectiva, a começar pelo veículo utilizado, a língua portuguesa, recheada, no entanto, de crioulidade (2008, p.03) 
O romance $O$ Escravo pertence à estética romântica iniciada por Camões (1825) de Almeida Garrett em Portugal e, no Brasil, por Suspiros Poéticos e Saudades (1836), de Gonçalves de Magalhães. Sabe-se que no Romantismo os ideais clássicos foram abandonados, bem como as regras de composição e de caráter prescritivo da crítica. Os pensadores alemães como Schiller e Goethe propunham uma nova literatura em que os aspectos sentimentais, reflexivos e pessoais preponderassem, tornando-se, assim, as possibilidades de composições artísticas infinitas. Além disso, o sentimento nacional exprimia o pensamento de que "a nação e o povo não são senão versões colectivas do 'individual'” (BUESCU, 1994, p. 72). Dessa forma, com o advento do romantismo, a história pessoal do sujeito refletia intimamente a história da Nação.

É nesse contexto de renovações estéticas e ideológicas que José Evaristo de Almeida se inscreve, oferecendo pela construção imagética do espaço geográfico e histórico de O Escravo, as bases iniciais da literatura nacional de Cabo Verde. Almeida apreende aspectos importantes da Cabo Verde em formação, apresenta a seu leitor a composição híbrida estabelecida pelos contatos entre os diversos povos que consituiram a população das ilhas e, atribui o papel de heróis-protagonistas a um negro escravo e a uma mestiça.

Ao tratar da temática da escravidão no romance, assume posições que podem defini-lo como um progressista naquele momento, denunciando os abusos da escravatura e as falhas do modelo colonial. Simone Caputo Gomes (2008) salienta que O Escravo 
[...] testemunha, em estilo romântico-realista, as atribulações de um amor camiliano (a escravatura do amor) condenado pelas barreiras de raça e classe e, ao mesmo tempo, a formação de uma sociedade com identidade crioula prestes a se desembaraçar do sistema escravocrata (a escravatura de condição) e dos seus ranços racialistas. (p. 01)

Segundo Antonio Carrera, o modelo de colonização portuguesa em Cabo Verde teve início na doação da ilha de Santiago a um nobre, o infante D. Fernando, como recompensa pelos serviços apresentados à Coroa. Esse mecanismo político era importante para o rei, pois, abstinha-se da tarefa de povoamento da ilha de Santiago e, ao mesmo tempo, concebia privilégios ao donatário, tal qual a plena jurisdição sobre as terras doadas (1972, p. 19). A nobreza assim servia ao rei pelo exercício de cargos militares e administrativos (p. 42). O povoamento da ilha de Santiago foi comprometido pelos baixos incentivos econômicos propostos por D. Fernando, pela falta de colonos portugueses dispostos a viver na ilha, dada a longa distância de Portugal, e pela dificuldade de adaptação ao clima árido, às condições de insalubridade e epidemias. Foram criadas estratégias de povoamento: ofereceu-se aos moradores um conjunto de incentivos na forma de privilégios, os quais abrangiam insenção fiscal e alguns privilégios de direito.

A Carta de 12 de junho de 1466 ortogou um conjunto de poderes aos moradores de Santiago, sobretudo, o de estabelecer o comércio de escravos entre Senegâmbia e a Europa, medida fundamental para a construção de uma sociedade escravagista em Cabo Verde (SILVA, 1995, v. II, p.1-16). O comércio de escravos era uma prática de Portugal e de outras potências colonizadoras, 
como a Inglaterra, a Holanda, a Espanha ou a França. O seu desenvolvimento explica-se tanto pela necessidade de dominação, como também pelo rendimento que proporcionava.

Após a descoberta das Antilhas, Cabo Verde tornou-se um grande entreposto do comércio de escravos. Na ilha de Santiago, muitos escravos passavam pelo processo de ladinização, um programa mínimo de "educação" que consistia no ensino de rudimentos de catequese e da língua portuguesa. Essa prática acaba por conduzir à distinção entre dois tipos de escravos: o escravo ladino que passara pela referida aprendizagem e já estava um tanto modificado, tendo por isso um valor maior; e o escravo boçal, que não tendo tido essa oportunidade, era considerado inferior.

Carrijo esclarece que o processo de benefícios cedidos para o tráfico de escravos aos moradores de Santiago ocorreu até a primeira metade do século XVI, pois, passa, posteriormente, "para as companhias particulares, que representam maior rentabilidade e menor risco [...]" (2008, p. 11).

O recurso ao escravo africano, condição necessária para o sucesso da ocupação da ilha de Santiago, tornou-se efetivo pelo privilégio concedido aos moradores de praticarem o livre comércio de escravos na Costa africana. Afinal, a própria colonização girava em torno do tráfico de escravos, concentrado nas mãos dos moradores o privilégio de serem "os únicos que podiam adquirir escravos" (AMARAL, 1964, p.190) e ter o trabalho da agricultura garantido. Durante os setecentos e o primeiro quarto dos oitocentos, a atividade da agricultura passa por declínio, explicados pelo governo de Cabo Verde, sobretudo, pela "ineficiência", "frouxação" e "fraca disposição para o 
trabalho" por parte dos escravos.

Depois de uma longa fase de pujança, o comércio de escravos começará a ser contestado e a ser objeto de mecanismos legais que visavam, primeiro, controlá-lo e, mais tarde, erradicá-lo. Apesar disso, Portugal será um dos países que persistirá até tarde no tráfico clandestino. Em Cabo Verde, de acordo com António Carreira (1972, p.383-84) apesar das medidas proibitivas e da vigilância constante, só em 1856 se concluiu o inventário normal dos escravos, num processo que visava à libertação dos que eram propriedade do Estado e à preparação para a cessação definitiva da servidão. Embora abolida formalmente, a escravatura persistiria ainda até 1877 , derrotada pela pressão mundial e pelas sucessivas revoltas de suas vítimas.

Com os vários acordos para a proibição do tráfico, derivado da assinatura dos tratados entre Portugal e Inglaterra, o morgado tem de se adaptar à proibição da escravatura e a um outro regime de trabalho, o que "marca a queda do morgado, explorada diretamente pela mão de obra escrava como elementos centrais da constituição e do funcionamento do sistema escravista" (SILVA, 1995, v. II, p.389).

Esses acordos estabelecidos na história de Cabo Verde, várias vezes, deixam de ser cumpridos, gerando conflitos, expostos no enredo de $O$ Escravo, ao apresentar o pai de Maria, longe do convívio familiar, em diligência para Guiné, para que resolva os protestos rebeldes dos gentios de Geba.

Simone Caputo esclarece que: 
A ilha de Santiago, nesses anos de oitocentos, é apresentada por José Evaristo como foco de insegurança política para as elites, pretexto que motivará os esforços da Coroa portuguesa no sentido de encontrar uma nova capital para o arquipélago, na ilha de S. Vicente. $(2008$, p. 02)

Em síntese, é nesse ambiente de crise interna, de disputa entre liberais e absolutistas, entre grandes proprietários e pequenos rendeiros, em meio das rebeliões e revoltas, que se situa a diegese do romance $O$ Escravo.

\subsection{O TeCido Do Discurso Romanesco De O Escravo}

\subsubsection{NARRADOR}

Gerárd Genette ${ }^{1}$, em Discurso da Narrativa (1995), considera que toda obra literária é um texto que possui um "todo de significação" e que produz em si mesmo seu sentido. Assim, a disposição de personagens no enunciado explicita as "vozes" que aparecem no texto. Analisa, como exemplo, o papel do narrador, destinador do discurso que se apresenta no enunciado com a capacidade de conduzir o discurso de diferentes modos, o que confirma as múltiplas possibilidades de vozes discursivas. Ora, se o narrador é o condutor

\footnotetext{
${ }^{1}$ Para o estudo sobre a teoria do discurso na narrativa de Gerard Genette tomam-se também como referências as pesquisas de Benilde Justo Caniato (1980 e 1988) e Eduard Calbucci (2007).
} 
do discurso e se essa condição pode ser construída de "diferentes modos", tem-se de observar a categoria da voz:

[...] aspecto - diz Vendryès - da ação verbal considerada nas suas relações com o sujeito - não sendo esse sujeito aqui somente aquele que realiza ou sofre ação, mas também aquele (o mesmo ou um outro) que a relata e, eventualmente, todos aqueles que participam, mesmo que passivamente, nessa actividade narrativa. Como se sabe, a lingüística levou algum tempo até balançar-se a tratar aquilo que Benveniste chamou de subjetividade na linguagem, ou seja, a passar da análise dos enunciados à das relações entre esses enunciados e a sua instância produtiva - o que se chama hoje a sua enunciação. (p.212)

O narrador é, nessa perspectiva, um sujeito nomeado, qualificado como tal por uma instância superior, que lhe dá a voz e o poder de conduzir o discurso. Essa instância remete à estrutura da enunciação, considerada como quadro implícito e, pressuposta pela existência do enunciado, inclui a figura do enunciador, cujo simulacro discursivo é o narrador. O processo de nomeação da voz constrói-se na enunciação, instância a partir da qual se projeta no enunciado aquele que vai falar. Há, portanto, dois papéis: o do narrador que está enunciado e do enunciador, que enuncia, sempre implícito, diferenciandose das demais vozes do enunciado. Apenas o narrador e o interlocutor têm voz no texto.

A enunciação, no romance, adquire uma dimensão coletiva, estruturada nas coerções psicossocio-históricas que se manifestam, sobretudo, 
pelas vozes de autoridade e de outra particular, nascidas da busca por uma voz capaz de produzir o efeito de individuação discursiva. Após enunciador e enunciatário se constituírem como sujeitos semanticamente competentes para produzir o discurso, os valores se realizam e, posteriormente, são projetados no enunciado, retalhando "um tecido de relações estreitas entre o acto narrativo, os seus protagonistas, as determinações espaciotemporais, a sua relação com as outras determinações narrativas implicadas na mesma narrativa" (1995, p. 214).

Esse destinador psicossocio-histórico influencia o enunciador como produtor implícito do discurso e o enunciatário como receptor implícito do discurso. O primeiro é o responsável pelas formações ideológicas no objetodiscurso; o segundo é quem avalia sua eficiência discursiva, o que coloca a proposta de Genette ao lado da historicidade, pois, ao percorrer os caminhos do destinador-manipulador e do destinatário-julgador, bem como os percursos temáticos pelo produtor e pelo receptor interpretante no texto literário, que contém o contexto do discurso, investiga-se o problema do contexto em termos das relações intertextuais.

A teoria de Genette homologa níveis de enunciados. O primeiro seria o extradiegético, correspondendo à própria ação de narrar. O nível extradiegético seria a instância da nomeação de voz, de instauração da diegese e do narrador no enunciado. Entendida como "universo espaciotemporal designado pela narrativa" (1995, p.273), o teórico aproveitou esse termo como sinônimo da narrativa, constituindo-se em modos de imitação poética ou tudo o que o poeta conta falando em seu próprio nome, sem tentar nos fazer crer que é um outro que fala - enunciador e enunciatário: 
A expressão nível extradiegético refere-se, no quadro da narratologia genettiana, a um aspecto particular do domínio da voz, ou seja, às circunstâncias que condicionam a enunciação narrativa e às entidades que nela intervém, compreendendo nessa intervenção a instituição no nível narrativo, em que se situa o narrador (REIS e LOPES, 2002, p.290)

A partir da extradiegese, institui-se o narrador, tem-se o nível diegético que corresponde ao segundo nível enunciativo - o do narrador e do narratário -; quando na diegese há outra narrativa, considera-se que ela pertence ao nível metadiegético, o terceiro nível enunciativo - ou seja, do interlocutor e do interlocutário. Para a diferenciação entre esses dois níveis deve-se perceber o estatuto narrativo entre a história contada pelo narrador (diegético) e a história contada por um dos participantes (metadiegético).

Essas observações genettianas contribuem para percepção dos valores expressos num enunciado que não dependem apenas de quem fala, mas também de quem vê, duas instâncias narrativas distintas. Identificar o narrador do texto ficcional é reconhecer quem fala e, além dessa questão de voz, existe um ponto de vista do qual os objetos da narrativa são considerados, implicando a avaliação de um enunciador. Assim, quem está por trás dele não é o narrador, mas o observador.

As funções do narrador remetem à necessidade de diferenciar o papel do narrador e do observador, pois, segundo Genette, essas funções exercidas pelo narrador são a narrativa propriamente dita, a de direção, a de comunicação, a de atestação e a ideológica (1995, p.253-55), e o sujeito da 
observação expressa o ponto de vista dos fenômenos narrativos, que se desdobra como "focalização" e se constrói pela relação sujeito e objeto. Por isso, faz-se a distinção: (i) entre o enunciador e o observador que ele cria; (ii) entre o narrador e o observador que o enunciador cria para ele; e (iii) entre o interlocutor e o observador que lhe determina a noção de realidade. Isso responde às questões problematizadoras de Genette: quem fala; quem observa; e quem, na análise enunciativa, age. Dessa forma, sempre será considerada sua ação na narrativa: o interlocutor é ator do enunciado, mas quando o narrador lhe delega a voz, passa a ser também ator da enunciação enunciada; o enunciador; o enunciatário, o narrador e o narratário são atores da enunciação, pois remetem à instância de produção de enunciados, porém, o narrador e o narratário podem estar sincretizados com um ator do enunciado e ser, ao mesmo tempo, um ator da enunciação e do enunciado. Já o enunciador e o enunciatário pertencem à instância da produção discursiva. Observa-se:

- Quem fala no texto é o narrador cuja voz lhe nomeou o enunciador. Ele pressupõe um observador e pode estar sincretizado com um ator do enunciado. O narrador, também, pode nomear voz a um interlocutor. Esse interlocutor é o ator da enunciação, pressupõe um observador e pode ser o ator da enunciação enunciada, quando o narrador lhe der a voz;

- Quem observa no texto é o observador, que está instalado no enunciado, cujo papel pode ser exercido pelo narrador ou outra personagem. Projeta-se sobre uma instância do enunciado;

- Quem age no texto é uma personagem do enunciado, que passa a ser mais relevante para a análise enunciativa quando se transforma em ator.

O estudo de quem narra, de quem observa e do modo como se 
narra, proposto por Genette, ganha importância teórica, pois auxilia no problema do foco narrativo. Para ajudar a desfazer a confusão do discurso e do narrativo, o teórico diz:

[...] a focalização pode ser entendida como a representação da informação diegética que se encontra ao alcance de um determinado campo da consciência, quer seja de uma personagem da história, quer do narrador heterodiegético; consequentemente, a focalização, para além de condicionar a quantidade de informação veiculada (eventos, personagens, espaços etc.), atinge a sua qualidade, por traduzir uma certa posição afetiva, ideológica, moral e ética em relação essa informação. (Genette in: REIS e LOPES, 2002, p.165)

E Genette acrescenta:

Com efeito, pode-se contar mais ou menos aquilo que se conta, e contá-lo segundo um ou outro ponto de vista; e é precisamente tal capacidade, e as modalidades de seu exercício, que visa a nossa categoria de modo narrativo: a "representação", ou mais exactamente, a informação narrativa tem os seus graus; a narrativa pode fornecer ao leitor mais ou menos pormenores, e de forma mais ou menos directa, e assim parecer [...] manter-se a maior ou menor distância daquilo que conta; pode também, escolher o regulamento da informação que dá, já não por essa espécie de filtragem uniforme, mas segundo as capacidades de conhecimento desta ou daquela das partes interessadas na história (personagem ou grupo de personagens), da qual se adoptará ou fingirá adoptar aquilo a que correntemente se chama a 
"visão" ou o "ponto de vista", parecendo então tomar em relação à história [...] esta ou aquela perspectiva. (1995, p.160)

Um dos elementos a influenciar essa focalização narrativa é o fato de o narrador assumir ou não o papel de ator do enunciado no discurso. De acordo com essa proposta, Genette defende:

A escolha do romancista não é feita entre duas formas gramaticais, mas entre duas atitudes narrativas (de que as formas gramaticais são apenas uma conseqüência mecânica): fazer contar a história por uma das suas "personagens" ou por um narrador estranho a essa história. A presença dos verbos na primeira pessoa num texto narrativo pode, pois, reenviar para as duas situações muito diferentes, que a gramática confunde mas a análise narrativa deve distinguir: a designação do narrador enquanto por si mesmo, [..] e a identidade de pessoa entre o narrador e uma das personagens da história [...] (1995, p.243)

O teórico nomeia, assim, no primeiro caso, o narrador homodiegético - figura que exerce posição de testemunha ou personagem secundária, solidária com a personagem central -, e o autodiegético - personagem central, que corresponde ao narrador ator do enunciado e da enunciação-; no segundo caso, o narrador heterodiegético - ator da enunciação que não participa diretamente das transformações narrativas (1995, 243-53).

O narrador heterodiegético divide-se em narrador-espectador e narrador-onisciente. O narrador-espectador está aderido a um observador 
absolutamente externo à narrativa e, uma vez que a estrutura do romance conduza o narrador a interessar-se pelos pensamentos e sentimentos dos atores do enunciado, ele apresenta algum tipo de onisciência.

Já o narrador onisciente associa-se ao observador, comanda as personagens, tem competência para saber o que vai acontecer com elas, o que sentem e pensam. E de acordo com o que ele vai revelar é o que define o foco narrativo, porque sempre incorpora o ponto de vista dos observadores, misturase a eles e da maneira como faz essa incorporação, adquire três patamares de onisciência: a seletiva, a multisseletiva e a total. Ele, ao filtrar a história através de uma personagem, limita o ponto de vista, geralmente, ao protagonista, abrindo mão de uma visão mais totalizadora da realidade. Utiliza-se do discurso indireto livre para misturar-se com o ator do enunciado e torna-se observador do narrador e do protagonista, que é marcado por traços típicos da fala da personagem.

O narrador onisciente multisseletivo produz narrativas filtradas por mais de um ator do enunciado e, por extensão, mais de um de seus respectivos observadores, recorrendo sempre ao discurso indireto livre.

O narrador onisciente total sabe tudo, comenta e avalia sem privilegiar nenhum observador dos atores da enunciação. Pode-se considerar que a maioria das obras do século XIX valeu-se do narrador-onisciente total como forma de valorizar o narrador, apontando-o no comando da narrativa. Essa escolha determina muitos efeitos produzidos por uma narrativa, como o suspense, a sátira ou a criação de expectativas.

Os efeitos dos focos narrativos desses tipos de narrador, citados, são 
sistematizados por Genette em: focalização parcial, subdividida em interna e externa; e focalização total (1995, p. 187-209):

- A focalização parcial interna caracteriza-se por ter matéria principal apreendida pelo observador de um dos atores do enunciado agrupado com o observador do narrador. Pode ser fixo - onisciência seletiva ou narrador protagonista; ou variável onisciência multisseletiva ou narrador testemunha e múltiplo.

- A focalização parcial externa é típica de narrador-expectador, em que se veem as ações das personagens, mas não seus pensamentos e sentimentos, pois se focaliza na exterioridade da cena e não se vê o íntimo do observador.

- A focalização total caracteriza-se por não ser nem exterior ao íntimo das personagens nem interior a uma delas. O observador é onisciente, sabe mais que as personagens e conhece os pensamentos e sentimentos de cada uma delas.

Em O Escravo, de José Evaristo de Almeida, o narrador mantém-se como sujeito do enunciado da ótica de um "ele" que, acoplado nas personagens, relata e comenta os acontecimentos. Esse narrador representado, de focalização externa, apresenta a matéria romanesca e as personagens, apoiado na sua opção pela protagonista Maria. O foco narrativo em terceira pessoa confere caráter objetivo, porém, não libera o narrador de interferências. A voz narrativa descreve e analisa o que pode ser verificado com 
os dêiticos - ali, em cima, perto -, denunciando a visão "de fora" ou focalização externa desse narrador.

O narrador inicia sua história em primeira pessoa do plural " na época em que nos referimos" (1989, p.25) e, em seguida, projeta-se na terceira pessoa do singular, como um narrador onisciente, afastando-se para contar a história dos protagonistas, da província de Cabo Verde e de sua estrutura social e cultural. Oscila entre o narrador heterodiegético e homodiegético, já que em algumas situações coloca-se como uma voz que participa da diegese. Retoma-se aqui, para maior clareza, a diegese.

O romance O Escravo divide-se em dezenove capítulos e está ambientalizado na ilha de Santiago em Cabo Verde. A narrativa gira em torno do amor incondicional do negro e escravo João por sua senhora Maria, mestiça livre, filha de um sargento indígena e uma mulata da elite.

A narrativa passa no ano de 1835 e inicia-se com a descrição da casa de Maria, localizada à Vila da Praia. O narrador descreve o ambente e os cuidados de Maria para com as flores, juntamente com os zelos dedicados a ela pelo escravo João. A personagem João conta a sua história: escravo do maldoso irmão de Maria, sofreu humilhações até quando este aos oito anos faleceu e o pai, Claudio Pimentel, deu-Ihe a filha Maria. A partir daí foi tratado como parte da família e educado a maneira européia. O escravo chega a desabafar dizendo preferir não ter o conhecimento recebido, já que na sua condição, o destino era imutável. Maria oferece-lhe a liberdade, mas ele rejeita argumentando que aos escravos libertos não são oferecidos os direitos dos nascidos livres. Na verdade, a maior escravatura de João desenvolvida na 
intriga é a de amor por sua senhora.

Claudio Pimentel viaja para uma missão em Guiné e Maria e a mãe recebem a visita de Lopes, "um verdadeiro tipo português, que por trazer uma carta de recomendação apresentando-o como oficial rebaixado por motivos políticos, é bem recebido na casa. Porém, Lopes encantado a primeira vista declara-se a Maria que julga o seu ato indigno acreditando que ele a quer por ser mulata e ele branco. Lopes sente-se humilhado ao ser descartado e promete vingança.

Pouco tempo depois, João estava sentado num muro em frente da casa ouvindo Maria tocar piano. Luíza, uma negra apaixonada por ele, começou a conversar com ele em crioulo. Percebeu o amor dedicado a Maria e resolve ajudá-lo, colocando-o no quarto da senhora enquanto ela dorme. Mas, antes Luiza convida João para irem ao batuque. A ação salta no tempo e é apresentada a casa do batuque, na Vila da Praia. É o lugar de reunião e diversão dos negros escravos. Há tambores, a dança do torno, contações de história e namoro.

Ali a personagem Domingos, velho contador de histórias, é convidado a contar uma história e ele relembra a história de Gomeseanne: Mariane, filha de um rico lavrador chamado Miguel Gomes é oferecida em casamento ao filho do sargento Mor, Manuel Dias Annes. Porem a moça tinha um amor secreto e na noite de núpcia quando não ocorrem os tiros de aviso de sua inocência, o pai ofendido vai atrás de Annes e desafia-o para um duelo. 0 noivo é morto. Os ouvintes perguntam o destino de Mariane e Domingos diz que talvez tenha virado feiticeira e qum poderia responder era Júlia, a negra 
feiticeira, também contadora de história. Ela relata uma história de muitas violências físicas e psicológicas: escrava do senhor Jerônimo Pimentel foi estuprada aos treze anos e deu a luz a um filho que ficou com o pai. Deixada de lado após o parto, pode iniciar sua vida ao lado do negro Luis e teve um filho. Quando Pimentel soube ameaçou matar a criança, com uma faca, se não contasse quem era o pai. Júlia revelou temendo-lhe a morte. Jerônimo tortura Luis até a morte e entrega Julia a todos os escravos. Sobre estupro e tortura, Julia é salva pelo bispo Pimentel, tio de Jerônimo. João ouve a história da feiticeira desconfia ser seu filho pela cicatriz que tem no peito deixada por uma faca.

Após a contação das histórias começa a dança do torno com a linda Luiza. No final João aproxima e marca o encontro no quarto de Maria para a próxima noite. Ainda nessa noite Lopes que estava no batuque e ouviu a história de Júlia, resolve aproveitar da revolta e ira demonstrada contra os brancos. Pede ajuda para convencer aos escravos a não se envolverem à revolta armada de Lopes.

O narrador muda o cenário para a Taverna do Tio Tesoura, onde Lopes e alguns militares se reúnem para conspirarem contra o atual governo em favor do rei deposto, D. Miguel. Planejaram a revolta dos militares. Nessa mesma noite, João adentra o quarto de Maria e não resiste aos seus encantos e beija sua mão, despertando-a. Diante do ocorrido, Maria oferece-lhe a alforria. João desesperado segue para o monte da sua mãe. È o dia 21 de março de 1835 e sua caminhada dura três dias. Ao chegar ao Monte Vermelho, não encontra Júlia e cansado adormece. Quando Júlia aparece, João expõe as suas suspeitas e ela o reconhece como filho. Júlia conta-Ihe as atrocidades 
recebidas e jura vingança, porém João teme pela família de Maria. A trama envolve agora o pai da Maria como filho bastardo de Julia e a vingança desejada em contrapartida ao amor incondicional de João para com Maria. Nesse instante, ouvem-se os tiros da revolta de Lopes e Júlia sente-se vingada. João se desespera e tenta ir socorrer Maria das garras de Lopes, porém Júlia o retém, eles rolam numa ribanceira, Julia morre e João desfalece.

Concomitante, acontece o levante planejado por Lopes: os revoltosos redem os oficiais e, Lopes é elevado a comandante com vivas ao rei D. Miguel nas ruas. Durante essa passeata ocorrem asasinatos de oficiais e saques e o narrador compara a crueldade dos soldados ao método da inquisição. Lopes envia um grupo de soldados para vigiar a casa de Maria.

Três dias depois do levante militar, a mãe de Maria pede socorro a João, pois a tropa de Lopes havia levado sua filha. João pega uma arma com dois tiros e sai à cavalo atrás do assassino e quando o alcança perto da calabaceira atira em seu cavalo, derrubando-o. Trava-se uma luta de espada e João é atingido, Lopes foge da tropa que vinha de encontro aos seus propósitos. Maria coloca João em seus braços, beija-o e João falece.

Maria é levada pela tropa e João, abandonado ao pé da calabaceira. Na cena seguinte Luiza e um escravo carregam o corpo de João até o Monte Vermelho. Ela havia pago para que o escravo a enterrasse junto ao corpo de João. Uma pedra esmaga-Ihe a cabeça. A diegese termina com Maria e a mãe mudando-se para Guiné a fim de encontrarem com Claúdio Pimentel.

A primeira providência do narrador de $O$ Escravo é atribuir verosimilhança à sua diegese, situando-a geográfica e historicamente. 
Em 1835 o sitio de B..., pouco mais de meia légua distante da Vila da Praia da ilha de São Tiago - uma das ilhas de Cabo Verde - não tinha ainda experimentado os melhoramentos, que hoje lhe dão a aparência de uma quinta européia. (ALMEIDA, 1989, p.25)[...]

E assim era; por quanto, na manhã de 2 de fevereiro do referido ano, quem aí chegasse, observaria uma cena pouco vulgar na Zona tórrida -a conversação quase familiar de uma senhora com o escravo(ALMEIDA, 1989, p.26).

As referências à história de revoltas em Cabo Verde, mais adiante no texto, fazem com que a ação narrada ancore-se nas referências internas a que remete a produção do romance. Os recursos empregados pelo narrador criam efeitos de realidade no discurso, tomando credíveis e de maior verossimilhança, visto que tais revoltas de fato se deram².

As duas horas da madrugada do dia 22 de março de 1835 , uma escolta de dez homens saiu do quartel, e foi postar-se às entradas da habitação do prefeito[...] A casa do tenente-coronel foi a última a que se dirigiram: este acordado para ir receber as últimas disposições de um moribundo oficial que chamava segundo Ihe dissera o seu impedido -foi agarrado [...] Ao começar da rua, a tropa, formada no quartel, rompeu em um entusiasmo viva a el-rei $D$. Miguel I: depois saiu toda fazendo acompanhar a música levando na sua frente Lopes, elevado à categoria de comandante [...]. (p.131-32).

\footnotetext{
${ }^{2}$ Claúdia Veiga afirma que do romance, consta em 1835, a revolta dos soldados, que está associada ao processo liberal, iniciado em Portugal, na década de 20, do século XIX. Em Cabo Verde ocorrem duas revoltas no referido ano: uma militar outra de escravo. Em $O$ Escravo há apenas referência ao levante miguelista o qual participaram soldados insatisfeitos aqui instigados pela personagem Lopes, isentando, assim, a participação dos escravos.
} 
O narrador marca a diegese numa sequência cronológica simples, fixando datas, horários, dêiticos temporais nos encadeamentos dos fatos das ações do texto. A intriga inicia em 22 de fevereiro de 1835 e termina com a partida de Maria e sua mãe para Guiné dois meses depois.

A narrativa é ambientada em acontecimentos históricos que sustentam a trama engendrada pelo escritor. Na pesquisa desenvolvida sobre O Escravo o pesquisador Lopes (2010, p.59) esquematiza os intertextos histórico-culturais do romance, numa linha pararela da história das revoltas ocorridas em Cabo Verde, reforçando em sua análise a verossimilhança dos aspectos recriados. Inicialmente apanha no primeiro capítulo a revolta dos negros na ilha de são Domingos, ocorrida na ultima década do século XVIII que conduziu à abolição da escravatura, em 1794, e à independência do Haiti, em 1804:

Numa ocasião reparei com a história da revolta de São Domingos. Ah! Essa noite foi para mim de um prazer indefinível! A narração das proezas daqueles negros despertou em meu peito sensações, até então, para mim desconhecidas. A ambição da glória entrou no meu espírito; esqueci o eu era: julguei-me livre!...Oh! e tão livre, que ao meu lado prendia uma espada...o delírio apossou-se do meu cérebro...e eu corria...corria com o fim de libertar meus irmãos do cativeiro. (ALMEIDA, 1989, p.29) 
Posteriormente, no segundo capítulo quando apresenta a família de Maria, o narrador dialoga com outra informação histórica de Cabo Verde: a forma de governo estabelecida na colônia:

No ano de 1812 governava a Província de Cabo Verde D.Antonio Coutinho de Lencastre. Os governadores, nessa época, intitulavam-se Capitães-gerais, e tinham prerrogativas, que hoje se não consentem aos atuais govwernadores. Uma, de não pequena monta, era a de poderem promover os oficiais subalternos até à patente de Capitão inclusive. (ALMEIDA, 1989, p.33)

Nesse mesmo capítulo, o narrador noticia o conflito entre a tropa do exército português e os gentios de Geba:

Havia seis meses que Cláudio - pai de Maria - tinha partido. Escrevera já duas vezes, na última - recebida pouco antes da conversação relatada no capítulo antecedente - ele participava que, em razão de uma pequena diligência entre a tropa e os gentios de Geba, ia partir para aquele ponto, de onde esperav em breve regressar ao seio da família. (ALMEIDA, 1989, p.35)

Mais adiante, o narrador apresenta a cena da visita de Lopes na casa da família de Maria. A personagem traz consigo uma carta de recomendação de um oficial chamado Caetano da Silva, amigo de Cláudio Pimentel. A carta trata da convenção de Evoramonte que reduziu os oficiais 
superiores a patente inferior. Essa convenção foi celebrada em 24 de maio de 1834 após o termino da guerra civil entre os anos de 1832 a1834:

Amigo Cláudio - Depois da última que te escrevi, bastantes desgostos têem passado pelo seu amigo. A desgraçada convenção de Évora-Monte roubou-me - assim, como a muitos - os postos superiores, de forma que me vejo reduzido à patente de alferes, que me foi dada quando parti em serviço para essa província. Contar-te-ei todos os promenores da campanha, se te não soubesse alheio à política, que felizmente para vocês - não exerce na África a mesma influência que na Europa. [..] (ALMEIDA, 1989, p.40-41)

A também referência a construção dos Paços do Concelho da Praia sobre as ruínas dum antigo edifício onde se situava a Casa da Câmara e Cadeia da Vila da Praia

$\mathrm{Na}$ rua da Igreja Matriz vem em linha directa interromperse no largo do Pelourinho da Vila da Praia, havia em 1835 uma taverna, stuada quase em frente da casa da Câmara e Cadeia da Vila; edificio que -naquela época -estavabem longe de presumir que de suas ruínas surgissem os elegantes e soídos Paços do Concelho, que hoje aformoseiam o largo. (ALMEIDA, 1989, p.81)

Quase não há elementos regressivos e o tempo está mais condensado, curto, pois é necessário para eclodir o conflito de tensão dramática (p.131) quando se enfatiza o golpe dos militares e a manobra 
absolutista em Cabo Verde, bem como o jogo do vilão Lopes em assegurar que os escravos fossem indiferentes à revolta. O levante militar na Vargem da Companhia apresenta-se no décimo sétimo capítulo de O Escravo:

As duas da madrugada do dia 21 de março de 1835, uma escolta de dez homens saiu do quartel e foi postar-se às estradas da habitação do prefeito. Logo e seguida uma outra de vinte -comandada por Aleixo -foi correndo as casas dos oficiais, os quais enganados pelos impedidos, davam-se pressa em vir fora cair na ratoeira que se lhes armara[...] (ALMEIDA, 1989, p.131)

Lopes (2010) destaca a ausência da rebelião de escravos, ocorrida em Dezembro de 1835 em Cabo Verde. Pontua que a verdadeira razão da omissão pode residir no tempo da diegese de $O$ Escravo, pois esta termina antes, com a partida de Maria e da sua mãe para a Guiné.

Cláudia Almeida (2009), todavia, oferece ao fato outra explicação. O motivo seria ideológico, pois no romance, o papel de vilão está reservado ao(s) branco(s). É significativo destacar como a pesquisadora traça os dados oferecidos no romance, cruzando os elementos de ambas as revoltas:

Os rebeldes do romance são soldados açorianos, mas algumas locações ali citadas são palco, de fato, da Revolta dos Escravos. Por exemplo: no local onde, no romance, teriam sido assassinados os oficiais pelos soldados rebeldes, chamado "Fonte Ana", perto da Vila da Praia, ocorreu o embate entre os negros rebelados e os brancos, na Revolta do mês de 
dezembro do referido ano. É ali que acontece uma emboscada aos negros, organizada pelos brancos que, com antecedência, haviam sido prevenidos por um escravo traidor. Portanto, o escritor mesclou, em seu romance, distintos episódios da história local, amalgamando ficção e realidade. (p.67-8)

Assim, pode-se considerar que o narrador insere o tempo da narrativa em dois momentos: um primeiro, mais lento, em que se utiliza de vários elementos regressivos, e um segundo mais rápido, com sequências lineares. A narrativa temporal submerge em anacronias, em manobras temporais em analepses, nas quais se identificam situações dos atuais eventos de partida. Assim, no primeiro capítulo, a narração enquanto ponto de vista temporal será "ulterior" e o presente tem o papel de "centro coordenador", permitindo, condicionando e interrompendo as digressões efetuadas no pretérito. O desenvolvimento da história é a partir de acontecimentos do passado, evocados insistentemente na narrativa.

Em relação ao momento, verifica-se um hiato no tempo, o que estabelece o vínculo entre o antes e o depois, dando a entender que o que ocorre nessa brecha temporal não é significativo para o relato. As sucessões são mais lineares, com elementos progressivos, a ponto de cada capítulo corresponder a dias ou um pouco mais.

Este conjunto de informações temporais demonstra a preocupação do narrador de manter-se fiel aos acontecimentos, apresentados como verossímeis. Apresenta-se como quadros que passam a ser registrados ordenadamente, conforme a sucessão temporal. Entretanto, apesar desta linearidade cronológica, há vários episódios narrados em analepse. No início 
do capítulo II, o narrador relata a história de Cláudio Pimentel: a sua vinda de Santo Antão, a rápida ascensão na carreira militar, apesar da sua condição de indígena, o casamento, o nascimento dos filhos, a compra da propriedade no sítio de B....

Há também o cruzamento de diegeses, criando uma história dentro de outra história como é o caso das diegeses narradas por Domingos e por Júlia: a primeira tem, sobretudo, um propósito recreativo, embora seja possível detectar alguma relação simbólica com a ação principal; a segunda é essencial para se perceber, não apenas a atuação de Júlia, mas também o passado do protagonista e a sua relação com Maria, de quem vem a ser tio.

O passado de Julia, de Maria e de João torna-se decisivo na vida presente, pois somente pelo passado, o discurso do presente se justifica, como um fio conduzindo ao outro, como categoria determinada a reger 0 determinante presente da história. A harmonia dos escravos e patrões soa como acontecimentos corriqueiros em Cabo Verde, porém avaliados passam a marcar os contrapostos da violência física e dos maltratos de proprietários não cristão. Os acontecimentos passados observados em seu estado de duração, ocorrem num contínuo de quadros da lembrança dele emanadas. João não morre simplesmente fisicamente: seus gestos, padecimentos, angústias e palavras duram como um quadro vivo e dinâmico, dentro e fora da personagem, fluindo sem cessar na narrativa.

Em relação aos procedimentos estruturais, apresentam-se coordenados ou subordinados, formando blocos narrativos, reinteirando situações semelhantes a fim de tipificar Cabo Verde. Estabelece assim, um 
encadeamento entre os capítulos através de idéia associativas, com seguencia narrativas no mesmo nível. Nos XX capítulos de $O$ Escravo as sequencias entrecruzam a história de João com a de Júlia, de Luíza e da família de Maria pelo vínculo familiar completando o sentido da trama, todas elas ligadas pela moral da história. A moral que é enfatizada pelo discurso narrativo do antes da escravidão e o depois, escravos instruídos e livres e escravos revoltados e assassinos, dois planos que se cruzam para redundar os aspectos da escravidão em Cabo Verde e da necessidade da reforma educativa e abolicionista. .

O discurso direto oferece a idéia de que a narrativa se conduz pela objetividade, isolando-se num contexto temporal definido, o que permite reproduzir os matizes e a peculiaridades das expressões das personagens que falam, aproximam o leitor da realidade ficcional e acentua a condiçao vivida por elas e sua humanização.

O final trágico de João encerra-se no tempo e reaparece dois meses depois "por míngua de engenho" a família de Maria a se reunir em GuinéBissau. O tempo reduzido condensa toda historia passada num instante narrativo, oferece ao leitor apenas a existência da continuidade mestiça. As demais personagens principais como João e Júlia ou ainda secundaria como Luiza, silenciam e desaparecem nos escombros da narrativa, deixando a dilatação da família nuclear mestiça de Cabo Verde, colorindo de "carinho e extremo cuidado" o universo criado. É metáfora de que em Cabo Verde a mestiçagem faz com que todos sejam parentes, alegoria da grande família.

O Escravo é um romance dominado pela pedagogia. Nele, Maria, 
uma das personagens românticas, é produto acabado das qualidades de seu meio e de sua criação, e dona de uma excepcional vitalidade de espírito que domina o enredo, irradiando a razão contra a obscuridade encarnada nas personagens Lopes, entre outros.

O narrador apresenta-a transitando entre os escravos sem preconceitos, encarnada do poder da sedução do entendimento e da virtude; sob sua influência desaparecem os vícios e as limitações de deformações sociais morais das mais diversas ordens. Toda a narrativa forma-se numa roda em torno da bondade e da inocência da personagem.

O discurso do romance $O$ Escravo apresenta-se pela tentativa de pactuação com a violência, tão abrangente e difusa quanto o esforço do narrador em tudo harmonizar. Na impossibilidadea da aliança entre o escravo João e a mestiça Maria há toda a extensão da coerção social pretendida no discurso narrativo.

Essa humanização deixa aparecer o substrato essencialmente violento que governa a relação escravocrata e seu mundo social correspondente. A ação discursiva a que o narrador se dedica consiste em converter essa massa enorme de violência social, difusa, em um pacto entorno do progresso de Cabo Verde. A coerção internaliza-se, por assim dizer, como regulador subjetivo das expectativas recíprocas das personagens: torna-se a índole benéfica do proprietário ou a amizade do escravo pela família. Constatase que todo o discurso aplicado nessa operação representacional indica a extensão da violência social que o narrador busca encobrir e converter em energia política para o progresso. Do ponto de vista desse discurso, a 
escravidão é apenas um aspecto funcional, embora extremamente significativo para a sociedade.

No romance caboverdiano $O$ Escravo, a violência é representada na forma de uma detenção amorosa e escrava, na diferença entre dono e propriedade, bem como na ação de uma força que pode ser identificada como a existência de um Estado colonial hierarquizado, que usa a discriminação racial e a tortura psicológica como normas correntes.

\begin{abstract}
-[...]Desenvolvestes em mim sentimentos que se não compadecem com a condição do escravo - mostraste-me o caminho do saber,entrei nele - caminhei a passos agigantados -mas chegando ao meio, uma voz sinistra me brada: "escravo" e eu recuo horrorizado! Abristes-me as portas do entendimento, mas quando busco ler no livro do meu futuro, encontro em todas as páginas a palavra escravo, escrita com caracteres pretos, oh! Pretos como o meu semblante!...[...]

-Ai de mim, senhora! Para que desenvolveste o meu raciocínio a ponto de reconhecer que o escravo pode nutrir heróicos sentimentos? Para que clarificastes a minha inteligência de maneira, que ela me leve a considerar o coração de uma nitidez bem oposta à escuridão do meu rosto?(1989, p. 29-30)
\end{abstract}

A pele negra das personagens escrava é vista sob um olhar racista. As falas subjetivas das personagens adequam-se ao acontecimento da história de João, permitindo que se transite do plano narrativo para o discurso "interior" da personagem. 
Isso acrescenta intensidade à cena, e reintera a construção do sujeito escravo negro no discurso. O exercício do poder colonial através desse discurso exige a articulação das formas da diferença racial. Portanto, demarca duas formas: o espaço teórico do conhecimento de si e um lugar político. Os modos de diferenciação enunciados entrecruzam-se perversamente num jogo calculado do objeto específico e estratégico de seus efeitos.

A insubordinação do escravo João que adentra o quarto de sua senhora, ao não se identificar pura e simplesmente como uma inépcia, parece remeter a esse tipo de ameaça que pairaria sobre o corpo social representado pela administração familiar da Colônia.

Com efeito, o universo referencial de Júlia, a escrava revoltada pelos estupros fisicos e psíquicos, não pode ser reconhecido, por isso, a solução fatídica: sua morte.

A carta de alforria transmite horror à personagem João. Para ele, a forma de sublimar a condição escrava, que ele reconhece como miserável apesar da bondade da senhora a que serve -está em poder ser escravo da própria amada. Dessa forma, o que realmente apavora o escravo é o preconceito social entorno de sua condição. Além disso, a escravidão cria o vínculo necessário para que se mantenha unido à Maria, preferível, portanto, à liberdade.

-Piedade! Piedade! ...De que me serve a vida longe de vós? Oh! Dai-me a morte ...eu vo-lo peço...Banido, meu Deus! Se a morte instantanea vos parece castigo leve, em relação à 
enormidade do meu delito, ordenai a tortura física: dai ao menos ao escravo a consolação de presumir que seus queixumes serão ouvidos por aquela, cuja presença é o único bem, que até aqui lhe tem sustentado a vida! Já é impossivel pertencer-vos pelo amor, deixai-me -como cativo -continuar a ser vosso. Nao, eu nao posso obedecer-vos! Ficarei aqui a vosso pesar; e nao a minha contumácia vos obrigará a ordenar o castigo que com ânsia vos peço! (1989, p.102)

Como se observa, é essa estrutura discursiva da escravidão que dá estrutura dramática e dupla ao enredo do romance: primeiro, a legitimação de propriedade e, segundo, o exercício intolerável e ilegítimo do poder que se articula na diferença do Estado Colonial e do Estado da Natureza. O tema central da obra passa ser a contradição entre o direito à propriedade - do dono sobre o escravo, e seu estatuto social, que se confunde com o papel de homem e da intensidade de seus desejos. Toda relação dramática da escravidão passa a derivar da própria condição jurídica do escravo. João nega até o fim sua liberdade, como que expondo a intensidade com que se aferrava à sua condição escrava, incompatível com a liberdade do homem, preferindo negar a si mesmo esse direito social. A escolha de João pela sujeição voluntária se dá como um sacrifício do homem apaixonado pela mulher Maria e patroa -motiva-se, portanto, pelo amor.

A nao aceitação de Maria dessa sujeição encaminha João à morte, quase como um suicídio, e se motiva pela salvação de Maria das mãos do vilão português. Sugere, também, que a sujeição de João deve ser sempre do nãoeuropeu, em favor do mestiço, para permitir o advento de sua liberdade. Nesse prisma, é possível ver na morte de João a denúncia da deformação social 
causada pela escravidão, concomitante a um caminho a seguir: a integração de uma etapa fundante de um projeto de Nação, pois se a morte marca a atribuição de papéis sociais bem-definidos, segundo uma hierarquia clara.

Portanto, a constituição das personagens, enquanto sujeitos sociais, é concomitante à atribuição hierárquica de papéis e indissociável dela. Esses dois movimentos na narrativa indicam o limite histórico da superação necessária à escravidão e a forma, também, necessária dessa superação. A liberdade como concessão e o sacrifício da "raça inferior" dão a chave de um movimento interno da obra em direção a ideia de "progresso". Por outro lado, a representação do escravo como sujeito e elemento do lugar sugere o sentido da escravidão para a constituição desta como um projeto politico. Como etapa transitória e positiva do progresso, a escravidão é exposta, simultaneamente, a suas contradições e nas suas virtualidades. É ela que introduz Maria nos quadros da família e da cidade, assim como é ela que dignifica João, pondo a toda prova a sua virtude.

O moralismo do narrador deseja impulsionar a família mestiça caboverdiana, célula fundante da sociedade, na direção da concessão da liberdade a seus escravos, ou seja, o discurso opera na ideia de que a família como elemento básico da Nação seria o agente da proposta de libertação. A extinção da escravidão projetaria a classe mestiça e proprietária a se elevar moralmente, pois somente esse modelo abolicionista elevaria ,por sua vez, moralmente, toda a sociedade.

Maria é o sujeito agente da transformação histórica que propõe José Evaristo de Almeida: senhora, respeitosa, amiga, afetuosa, dedicada à família e 
zelosa da humanidade de seus escravos, decide, sem lei que a obrigue, dar a liberdade a João, plenamente consciente do sentido redentor e moralmente elevado desse gesto. Ela é a voz da consciência narrativa que o enunciador quer atingir. No jogo da atribuição de papel, é uma jovem instruída, mestiça e livre. Não são brancos ou ricos como Pimentel que dão a direção moral do enredo. O sonho de um sistema educativo e uma crença na política cristã para a reforma que daria ao habitante da Colônia uma identidade pessoal como o enunciador concebe: dividido entre essa duas forças e o medo de que os escravos pudessem se tornar turbulentos em busca da liberdade.

O móvel pedagógico e didático do romance de $O$ Escravo é o de atribuir a essa personagem um papel transformador, que supera a escravidão quando institui uma ordem social integrada, segundo a atribuição hierárquica de posições. É ela, por conseguinte, a voz responsável pelo duplo movimento, no fundo o mesmo: incorporação subordinada do escravo à sociedade burguesa e de delimitação de seu lugar social.

A transformação de que essa protagonista é agente também a afeta, pois o seu escravo é apaixonado por ela. Encarna, portanto, a perfeição do mestiço, fruto do processo escravagista:

Nao há assim, entre nós, castas sociais perpétuas, nao há divisao fixa de classe [...] esse ente, assim equiparado, quanto à proteção social, a qualquer outra coisa de dominio particular,é, no dia seguinte à sua alforria, um cidadao como outro qualquer, com todos os direitos politicos, e o mesmo grau de elegibilidade. [...] Isso prova a confusao de classes e individuos e a extensão ilimitada dos cruzamentos sociais 
entre escravos e livres, que fazem da maioria dos cidadãos, se se pode assim dizer, mestiços politicos, nos quais se combatem duas naturezas opostas: a do senhor de nascimento e a do escravo domesticado. (NABUCO, 1989, p. 82)

Daí sua ambiguidade: oferecer alforria concebendo a liberdade, produz elevo; quando porém a escravidão amorosa se impõe, rebaixa-se moralmente. O discurso político projeta Maria como senhora destinada a formar nova família, agora "melhorada pela mestiçagem".

O percurso da personagem pelo esclarecimento traduz e efetiva a reforma dos costumes por meio da compreensão, por parte de senhores escravos, da injustiça fundamental da escravidão. O romance é o veículo móvel dessa prática educativa e, como objeto estético, cabe reconhecer que sua estrutura é tessitura de valor artístico, pela realização acabada que celebra a formação da família burguesa e mestiça sob o beijo no leito de morte dos protagonistas Joao e Maria. A escravidão o condenara, mas a virtude da mestiça como virtude da Nação, é restituída na verdade de sua condição.

Ora, o conceito de raça de José Evaristo de Almeida coaduna-se com o pensamento para o qual a mistura de raça é uma lei virtuosa da evolução da humanidade. A mestiçagem é para o escritor de Cabo Verde um valor de importância na medida em que permite a absorção da "raça inferior" pela "raça superior", com a consequente elevação daquela. Trata-se da mestiçagem de certo modo dirigida, mas ainda assim como índice de raça cuja operação é matizada pela história. 
Do ponto de vista da escravidão como tema, O Escravo, pela forma como o próprio enredo se articula, traduz a estrutura do conflito dramático da questão social. Daí a intensidade do meio empregado por José Evaristo e Almeida para estruturar o seu romance sobre a escravidão: cria protagonistas escravo/negro e mestiça/burguesa e institui o diálogo como textura da obra, colocando-os como agentes da própria ação e enunciadores da propria voz. Trata-se de um efeito estético que oferece autonomia a personagens negros e mestiços, ao mesmo tempo que mostra as contradições que a escravidão encerrava.

Naturalmente, os recursos estéticos de José Evaristo de Almeida encerram as forças históricas. O escravagismo "criou situações nas quais o escravo, tendo se transformado em ferramenta-inteligente, negava em seu comportamento as representações que dele eram feitas" (CARDOSO,1997, p. 240). Nesse sentido, o escravo doméstico, a exemplo de João, espelhava, na intimidade da casa, a sua humanidade e punha em contradição o seu estatuto jurídico de coisa, provocando uma ambiguidade inescapável no comportamento dos senhores.

\subsubsection{ESPAÇO}

Entre as várias armadilhas de um texto, o espaço pode alcançar estatuto importante tanto quanto outros componentes, tais como: foco 
narrativo, personagem, tempo etc. É bem verdade que em certas narrativas esse componente vem diluído e, por esse motivo, sua importância é secundária. Em outras, ele é prioritário e fundamental no desenvolvimento da ação, quando não determinante. A terceira situação, mais fascinante, é quando ele é atribuído funcionalidade e organicidade, harmonizado com os demais elementos narrativos, favorecendo certo equilíbrio entre eles.

Osman Lins na sua obra Espaço e romance (1987) no capítulo intitulado "Rumos aos conceitos", e na obra Lima Barreto e espaço romanesco (1976) contribui com a teorização acerca do espaço, distinguindo espaço e ambientação:

Por ambientação, entenderíamos o conjunto de processos conhecidos ou possíveis, destinados a provocar, na narrativa, a noção de determinado ambiente. Para a aferição do espaço, levamos a experiência o mundo; para ajuizar sobre ambientação, onde transparecem os recursos expressivos do autor, impõe-se um certo conhecimento da arte narrativa. (LINS, 1976, p.77)

Com essa distinção, observa-se que o espaço é denotado e a ambientação é conotada. O primeiro é patente e explícito; o segundo é subjacente e implícito. O primeiro contém dados de realidades que, numa instância posterior, podem alcançar uma dimensão simbólica.

Vale acrescentar a definição de espaço dada por Carlos Reis em seu Dicionário de Narratologia: 
Entendido como domínio da história, o espaço integra, em primeira instância, os componentes físicos que servem de cenários ao desenrolar da ação e à movimentação das personagens: cenários geográficos, interiores, decorações, objectos, etc; em segunda instância, o conceito de espaço pode ser entendido em sentido translato, abarcando então tanto as atmosferas sociais (espaço social) como até as psicológicas (espaço psicológico). (1994, p. 135)

Convém distinguir, portanto, os dois tipos de espaços que se pretende analisar: espaço natural e social. Nelly Novaes Coelho (in: LINS, 1976, p.74) menciona o ambiente natural como equivalente à paisagem, à natureza livre; o ambiente social seria a natureza modificada pelo homem: a casa, castelo, tenda etc. Daí o espaço natural se relacionar com o ambiente natural e o espaço social com o ambiente social. É, sobretudo do último que fala Carlos Reis, quando escreve:

Num plano mais restrito, o espaço da narrativa centra-se em cenários reduzidos: a cãs, por exemplo, dando origem a romances que fazem dela o eixo microcósmico em função da qual se vai definindo a condição histórica e social das personagens. (1994, p.136)

\section{- Espaço Natural}


O espaço natural em O Escravo aparece como cenário, enquanto marca do tempo e estados e ações das personagens, plasmando a maneira de ser, existir, atuar, reagir e de expressar. $O$ narrador cria a imagem estabelecendo analogias com as personagens e os fenômenos da vida vegetal e animal, da natureza enfim.

O Escravo organiza-se numa sequência de dois segmentos apresentados dentro da situação mencionada no título da narrativa - $O$ Escravo - e em alguns subtítulos, tais como: "João - o escravo"; "Reunião de escravos - uma história".

Em virtude de uma disposição espacial, os segmentos vinculam-se ao cenário físico-humano de uma ilha do arquipélago, a de Santiago, objetivando, num primeiro plano, por em evidência a dinâmica da vivência e percepção do homem caboverdiano num tempo em que a ilha não havia "experimentado os melhoramentos" da moderna Europa, e num segundo plano, a sua estaticidade.

Ao iniciar a leitura de $O$ Escravo, percebe-se nas primeiras palavras que o "narrador-paisagista" as destinou para caracterizar o tempo da história e as personagens humanas. Ao descrever o sítio de B..., a paisagem terá papel de destaque na abertura do romance, reservando-se as linhas iniciais da história à geografia do local. A descrição é deveras longa:

Em 1835 o sitio de B..., pouco mais de meia légua distante da Vila da Praia da ilha de São Tiago - uma das ilhas de Cabo Verde - não tinha ainda experimentado os 
melhoramentos, que hoje Ihe dão a aparência de uma quinta européia. Contudo, apesar da falta de arte no seu amanho, com quanto não houvesse ali outra cultura além das plantas indígenas, nem por isso deixava de ser aquele sítio - na época a que nos referimos - um dos mais aprazíveis para quem saía da Vila da Praia, cuja aridez contrasta singularmente com a vegetação constante de um ponto que Ihe fica tão próximo. E quem sabe? Talvez alguém, entendendo que a arte, à força de regularizar, estraga muitas vezes a poesia dos campos, e torna monótono o que a natureza criara de romântico, achasse mais novidade - e por conseqüência maior deleite - em contemplar a ribeira, ora espreguiçando-se à vontade, ora caprichosa afastando-se do seu leito; serpenteando acolá, subdividindo-se aqui; umas vezes ligeira, outras enamorando-se a brincar com o arbusto, a que ela dá vida, com o ramo que a beija, com a pedrinha, que poliu à custa de afagos: talvez - diremos - achasse mais prazer em observá-la assim - tal qual a natureza a formara do que vê-la subordinada a certos regos, que a enfraquecem, que a torturam, que a forçam desde a sua origem -já fazendo-a subir mais do que ela pode -já obrigando-a a desprender-se de uma parte de si mesma, para assim mais facilmente ser engolida pela terra sequiosa, de que ela queria escapar-se. (1889, p.25)

Estes segmentos apresentam-se vinculados, interprenetrados por um narrador que procura dimensionar o homem caboverdiano em seu ajustamento. A natureza do riacho, imagem do universo caboverdiano, caracterizador das personagens que abriga, impregna-se de uma conotação de espaço ambíguo: a dimensão finita de sua condição natural, sugerida pela clausura dos regos que limitam e aprisionam, indicando a realidade espacial do homem caboverdiano, já determinado pelo elemento catafórico e explicativo de sua 
condição: a escravatura. $\mathrm{O}$ povo caboverdiano composto numa imagem de liberdade e dinâmica, tendo que se enclausurar diante dos propósitos do progresso, ditados pela colonização.

Há na constituição verbal "diremos", a enunciação do narrador associado ao enunciador iniciando uma interlocução com o narratário. Essa formulação é o indício de que o narrador estabelecerá, muitas vezes, uma relação harmoniosa com o narratário.

Trata de uma ambientalização franca, segundo a terminologia de Osman Lins, em que o narrador não participa da ação, mas se pauta pelo descritivismo. Mas esta descrição não surge como mera informação, não tem apenas um caráter de conhecimento informativo. Salta aos olhos a preocupação do narrador em organizar um quadro objetivo e globalizante da ação.

Além de apresentar a indicação temporal do ano que se passa a ação, o autor localiza geograficamente a narrativa em Cabo Verde, em uma casa construída no meio de uma floresta tropical. Chama atenção para o ambiente natural, isto é, para a natureza e sua beleza.

Nele, o narrador acompanha o passeio pela natureza rústica, faz uma descrição acentuada da paisagem com destaque na beleza da plantação indígena, da aridez singular e da ribeira com um olhar observante da realidade vivida. O narrador com minúcia descritiva, ao mostrar essas belezas da terra, deixa transparecer a ideia de conhecedor da natureza caboverdiana. À maneira de um viajante naturalista, volta-se para a capacidade de fixar a paisagem, descrevê-la e nomeá-la. 
Ela, a jovem que tratava de objetos tão queridos ao seu coração, de objectos inocentes como a sua alma, puros com o seu pensar - diremos, toda entregue a essa ocupação tão grata às almas, que as flores simbolizam - não repara que um cem-pés Ihe subira pela manga do roupão, e estava a ponto de invadir-Ihe o colo, que -por estar nu -a brisa beijava a seu belo prazer (ALMEIDA, 1989, p.26).

O narrador está à procura de um espécime raro, localizando as espécies de árvores frutíferas e o clima quente dos trópicos. As descrições causam, pela composição dos elementos díspares, sensações colhidas da observação, em que, mesmo ausente, a ação humana subjaz na descrição da personificação da ribeira que espreguiça, serpenteia erótica e caprichosamente, brinca, beija e afaga a natureza em seu redor, ou ainda, da "brisa [que] beijava a seu belo prazer" (1989, p.26) o colo nu da protagonista. Nesse fragmento da descrição da natureza tem-se a ribeira como elemento simbólico, em que a conjunção de personificação da natureza reforça a imagem dos protagonistas João e Maria, tornando-as ideais, personagens que traduzem o anseio romântico do enunciador.

O lugar é encantador e paradisíaco, com a ribeira livre, porém, o narrador determina a possível quebra dessa harmonia natural pela imposição de outros sucos que podem enfraquecer, torturar e forçar aquilo que já nasceu livre.

A ribeira apequenada, e com toda sua rapidez e agilidade, transforma-se em calmaria e mansidão próprias de um lago. Dessa forma, a 
descrição da ribeira do jardim da casa da protagonista parece ser feita num vaie-vem de pequenez e grandiosidade. Duas comparações alusivas a situações sócio-históricas distintas impõem-se: a ribeira livre e a ribeira aprisionada. $A$ comparação com uma ordem social revela o peso do momento histórico entre os românticos; evocando à ordem escravocrata - vinculação direta com o tempo da narrativa. Registra-se a alusão das relações de dominação, quer de vassalagem, quer de escravidão, entre os elementos da natureza. Não é a imagem de uma ribeira dominada que o narrador quer oferecer ao interlocutário, mas a memória da imagem de uma ribeira livre, que se rebela e busca sua independência, podendo ser o que realmente é, não tendo de se curvar.

Dessa forma, nesse recurso de comparação, pode-se ver na ribeira a própria colonização portuguesa em Cabo Verde. A ideia de uma nação livre, de uma cultura peculiar, tal qual prevê o ideário romântico, apresenta-se em 0 Escravo na luta da ribeira para não se subjugar ao movimento de uma serpente, que traça um caminho sinuoso. O narrador busca elementos da própria natureza para caracterizar a ribeira exaltando-o a própria natureza em suas qualidades.

Observa-se, na imagem citada, a proposta de retrocesso para um lugar remoto, a fim de se falar em autonomia, e para uma época passada, na qual a nação caboverdiana já existiria. Uma referência mais explícita para esse aspecto saudosista da narrativa seria o interesse pelo passado histórico no romance (revisão do momento histórico) e a importância da autenticidade local, personificada na liberdade da natureza. 
Somente quando está terminada a apresentação desse espaço inicial, é que se sai do preâmbulo espaciotemporal para a efabulação. Nessa abertura de texto, enunciador e narrador se equivalem, produzindo um sentido de referencialização, de realidade à diegese. Assim, as particularidades semânticas do enunciado de $O$ Escravo incluem a natureza livre homem/ribeira -, e a natureza escrava - homem/regos, espécie de libertação temporária da realidade.

\section{- a Casa-Espaço Do Sublime}

A casa tropical de Maria pode ser interpretada no romance como a fundação de Cabo Verde, num encontro da cultura portuguesa com a cultura africana e com a natureza subjugada. A delimitação espacial do universo diegético, tornando a casa centro da ação que irá se desenrolar, pode sugerir aspectos significativos da concepção do modo como o narrador apresenta a caboverdianidade.

Percebe-se, também, no espaço da casa, a equivalência entre elementos naturais e elementos arquitetônicos. É no passeio no interior do jardim da casa que Maria e Lopes se deparam com "o rego formado por uma telha de água que ali ainda hoje escorre" (1989, p.43). A situação de perigo em que se encontra Maria aparece nos termos "íngreme ladeira" e "fornalhas", que remete ao inferno em contraponto com a abertura do primeiro capítulo. Isso leva a considerar que a personagem Lopes, branco, militar, constitui-se como 
elemento negativo e demoníaco em contraste com o negro escravo, elemento de completude da natureza-feminina.

A função da natureza da ribeira em $O$ Escravo tem origem numa concepção teatral do enredo. A construção plástica do cenário indica a elaboração do espaço como elemento revelador da feição das personagens e dos conflitos narrativos. A ribeira, com sua característica faceira, refere-se à Maria em sua meninice e inocência natural. Na relação entre a ribeira e outros regos, a autoridade se impõe, delineando o perfil de Lopes, militar português desleal e perigoso.

Assim como a ribeira, o canteiro das flores constrói a imagem de beleza física, misteriosa e sensual que caracteriza Maria. Observem-se os fragmentos:

[...] havia, então três canteiros, e alguns vasos, dispostos de maneira, e contendo flores tão frescas que ao vê-las facilmente se adivinhava, que mereciam os desvelos de femininas mãos. (p.26)

Ela, a jovem que tratava de objectos tão queridos ao seu coração, de objectos inocentes como a sua alma, puros como o seu pensar - ela, dizemos, toda entregue a essa ocupação tão grata às almas, que as flores simbolizam [...] (p.26)

[...] quem me diria que entre estas flores, que eu tanto prezo, se havia de esconder tal sevandija! Mas, nem por isso, eu quero menos às minhas flores: se elas pudessem falar, de certo me teriam avisado do perigo que me estava iminente; terme-iam prevenido de que se serviam delas para me molestarem. Mas elas não falam; só podem manifestar-me a 
sua alegria, apresentando-se-me viçosas e belas; e eu as compreendo todo o seu pesar, quando após uma noite tempestuosa as encontro flácidas e tristes. Se Deus lhes tivesse dado o dom da compreensão, como lhes dou um tão delicado sentir, ensinar-lhes-ia que não se fizessem fortes com o vendaval que as mata; e que - em vez de resistirem dobrassem o colo, erguendo-o só quando estivessem bem certas de que o inimigo estava longe. Praticava com elas o mesmo que pratiquei contigo, meu João; far-lhes-ia aprender quanto meu pai me ensinou; e assim como cultivei o teu espírito, eu desenvolveria o de essas inocentes flores que me dão instantes de pura satisfação. (p.27)

Maria é a flor do jardim matizado, fresca e pura, aquela que sacia a sede, que tem a função de ser atrativa ao polinizador. Sua fragilidade e graça apresentam-se como natureza vegetal, feminina e emotiva. Como um ser refletivo, educada para o ensino da resistência aos domínios da natureza física, como tempestades e vendavais, ou psíquicas como o da escravidão. Nessa passagem, pode-se considerar implicitamente o inimigo desleal - a condição escrava, como aspecto negativo que deve ser atacado com prudência e sabedoria. O objetivo parece ser o de proteção, comportando-se como uma guerreira que conhece a força do inimigo e arma-se com o jogo estratégico da suposta submissão.

Sendo assim, mais do que um representante africano negro, João, possui prudência e sabedoria dignas de um varão e, por isso, consegue forças para enfrentar a escravidão: é cristianizado, possui características da nobreza, humildade, lealdade, imputados ao elemento africano. É o discurso do narrador que opera pela manutenção da origem africana e negra, mas absorvida pela 
cultura do colonizador. A europeização é tomada aqui como forma de evolução do povo primitivo, mas ainda assim subserviência ao colonizador.

A descrição do ambiente relacionada aos aspectos psicológicos das personagens destaca-se no texto. É a personagem, por meio de suas sensações, que gera o ambiente. Observa-se na linguagem empregada, a escolha do léxico e das expressões uma adequação de percepções à subjetividade das personagens. A natureza torna-se reflexo das personagens, de suas ações e reações.

Ressalta-se que as longas descrições de elementos naturais no romance de José Evaristo de Almeida não são meros cenários ou panos de fundo. O papel da natureza, sobretudo no Romantismo, é fundamental para o desenvolvimento da diegese. O narrador, imbuído da missão de escrever um romance que narrasse aquilo que é peculiar de Cabo Verde, vê na exaltação da natureza uma forma de despertar emoções nativistas no interlocutário. A descrição mimética da natureza visa demonstrar que o indivíduo é fruto das condições do meio, por isso, ela não pode ser tão somente pano de fundo.

Essa geografia metafórica também é local de refúgio das personagens. Ao expor o isolamento da alma sensível, a natureza assume um papel de destaque, pois se revela como um refúgio sentimental, onde o homem tem possibilidade de encontra a si mesmo. Assim, a natureza aparece como uma revelação do infinito, do transcendente.

A imagem é explorada pela descrição eloquente da imensidão sublime da paisagem tropical e da coloração cintilante, bem como da representação sentimental de liberdade, tomada como traço positivo do caráter 
da natureza do africano. A natureza deleiteia-se indomável, uma demonstração do sublime sobre o qual não se tem controle.

No entanto, como foi observado, a natureza é descrita com sua imponência, grandeza e graça, não primeiramente pelo escapismo, e sim para reforçar a grandeza do valor local, de seus costumes e de seu povo. Recriada em seu esplendor, aponta a identidade dessa colônia. Os caracteres de refúgio e até de eroticidade apenas complementam essa imagem.

Convém assinalar que a descrição explosiva do ambiente natural não foge ao desejo do narrador de valorizar a cor local, convidando o interlocutário a conhecer a região. Observa-se o esboço do quadro espacial panorâmico para destacar a flora local:

Em 1835, ainda ali não havia, nem as azedinhas, nem as ameixeiras, nem as pereiras nem outras árvores, que, em seis anos tem crescido muito, copado pouco, e que - como saudosas de seu país natal - permaneceu tristes, temendo expor seus frutos aos raios abrasadores de este sol africano. Mas, em seu lugar vereis fartas laranjeiras, abundantes bananeiras, o cajueiro, o zimbrão, a norça, os tamarindos, as palmeiras altas, tão altas, tão altas que podia dizer-se eram as primeiras a saudar o sol. Nem faltava aí o rubicundo café; a cana-de-açúcar, que parece ornar-se - quando florida - com as elegantes penas das aves-do-paraíso. Não existia, é verdade, um jardim tão matizado, tão fértil, tão variado como o de hoje; mas no local onde actualmente está uma horta, havia então três canteiros, e alguns vasos, dispostos de maneira, e contendo flores tão frescas e viscosas, que ao vê-las facilmente se adivinhava, que mereciam os desvelos de femininas mãos. (1989, p.26) 
O ambiente é descrito de modo primoroso pelo narrador: a descrição assume um ritmo poético e se apresenta diante do leitor como um quadro. Aparece a superioridade da beleza natural sobre a imagem criada ou inventada pela arte. Cria-se um mecanismo de composição presente no relato descritivo, com sentido específico de determinar as características marcantes da região, e esses adquirem dimensão na narrativa, responsabilizando-se pela autenticidade do real. As sensações externas se mesclam àquelas interiores, quando, após a liberdade-aprisionamento da ribeira, surge o Sol e o delírio multicolorido dos tipos de plantas da paisagem. As imagens compõem o universo harmônico do jardim da casa, em que o narrador se coloca como espectador e artista dentro da experiência vivida.

Assim, tem-se a revelação de uma casa de Cabo Verde paradisíaca, pintada sem a presença do branco europeu. Maria e a natureza se igualam, se comunicam perfeitamente. Da mesma forma como descreve a natureza ao redor, o narrador descreveu Maria, colocando-a no mesmo plano do cenário natural, do ambiente. Maria não só se iguala à natureza ao seu redor em esplendor, como a supera. A personagem do tipo heroína tem, entre seus traços de família, o domínio sobre as plantas. A elegância da ave-do-paraíso que compõe a cena remete à ideia de liberdade, de tranquilidade, o que está ligado à imagem da personagem Maria. Livre, no domínio de suas ações, respeita o mundo a seu redor e é respeitada por ele, o que complementa a perfeição imagética da ambientalização natural. 
A harmonia da natureza, a tranquilidade e a beleza da virgem mulata só são rompidas com o aparecimento de um cem-pés a subir pela manga do roupão de Maria e invadir seu colo. A harmonia da personagem com a natureza é rompida, violentamente, pelo parasita venenoso. É a quebra da cadência, da tranquilidade do espaço da personagem e do seu escravo João. Essa imagem da perturbação harmônica entre escravo e senhora pela sevandija é a metáfora repetitiva do vilão português, o senhor Lopes, que passa a existir no terceiro capítulo da narrativa. Parece inaugurar, então, a chegada de um tipo de colonizador ou de colonização, fim do paraíso edênico dos protagonistas, o paraíso de Cabo Verde, nas suas raízes, por causa do perigo futuro, representado no veneno do cém-pés:

De um salto transpôs o escravo o espaço que o separava de sua senhora, e subtil - como o hábil operador, cujo escalpelo apenas corta a porção que lhe é destinada ele deitou por terra o venenoso insecto, sem que os dedos tocassem, nem de leve, em sua senhora. (1989, p.27)

Igualmente é a reação de Maria ao se sentir ameaçada por Lopes. A comparação da protagonista como um feroz tigre ilustra a dedicação de Maria, tentando proteger a honra de sua família, seus ideais e enfrentar aquele tipo de homem branco:

Lopes não pode continuar: ele viu em pé, na sua frente, Maria, mostrando no semblante uma expressão de rancor indefinível só comparável à da mulher fulminando uma rival. 
Viu-a, impondo-lhe silêncio com a mão, com o braço, com o gesto - por que a voz fugira-Ihe arrebatada por um acesso de cólera [...] a ferocidade do tigre. (1989, p.45)

Ao fixar a paisagem, o narrador vai dando corpo ao registro da vida caboverdiana como um todo, numa visão de conjunto que abarca o que há de mais característico na natureza. Limita o seu campo de observação, focalizando aspectos da vida cultural identitária da personagem João:

Cinco minutos depois, João avistou Lopes - cujo cavalo á não corria, fatigado pelo duplicado peso de dois corpos avistou-o quase chegando à Calabaceira.

Esta formosa árvore, cujo tronco - com dezassete braças de circunferência - conserva milhares de nomes que ali tem gravado quantos a tem visto de perto, convida por seus copados ramos a gozar da sombra que ela oferece ao cansado viandate, deslumbrado pelo intenso sol que o acompanhou todo o caminho. (1989, p.147)

A natureza revela João, comparado na narrativa com pedras, rochedos, minerais ou com uma árvore, como a Calabaceira ou Baobá, espécie que apresenta um tronco grande e duro, lugar sagrado de repouso dos espíritos. A masculinidade é expressa nas comparações em que a natureza física separa os elementos femininos dos masculinos. Ele é a rocha, a resistência, um guerreiro, com sua força e honra. A árvore majestosa serve para gerar sombra e refúgio para o que está ao redor. O fato de o narrador utilizar a árvore do Baobá ou Calabaceira, própria dos trópicos africanos, representa maior aproximação de João com o elemento natural, de resistência e pujança. É mais que uma árvore, é o símbolo do guerreiro que em vez de se 
quebrar com o vendaval, não teme e enfrenta todas as adversidades, contrapondo-se à fragilidade da ave-do-paraíso, colorida, e da flor de caule fino e frágil. Ali, na Calabaceira, João cria raízes, da mesma forma que atingiu o coração de Maria, como se fosse árvore e não pudesse sair do lugar. 0 formoso Baobá se eleva às nuvens enquanto a rama se humilha, sacrifica-se, insinuando o final do romance: o sacrifício do homem africano para a conquista do outro, do colonizador europeu, o que denota pontos relacionados à ideologia colonialista.

\section{- A Casa - Espaço Do Grotesco}

Em contraposição à natureza da casa da protagonista, surge a natureza da casa de Júlia, no capítulo "O antro da feiticeira", com paisagens de “achadas escaldantes", “abismo”, “inacessível monte”, "ruínas”, um lugar inóspito "que jamais manifestou sinal algum de vegetação" (p.111). O espaço expressa a exclusão social em que vive a personagem: antro medonho, a gruta metonimiza-se como lugar inabitável, monstruoso e sepulcral. A cena concentra a imagem: o precipício sombrio e perigoso, a montanha alta e escarpada, insinuando um mal presságio:

Disposto a levar a cabo sua empreitada, não duvidou de atravessar de rojo aquela estreita guela, que felizmente não 
tinha uma braça de extensão [...] alongou a esquerda, não pode distanciá-la além de um palmo; para frente foi preciso estender-se completamente, para encontrar o fim da caverna. Minutos depois seus olhos viram claro. Oh, mas antes não ver! Aquele antro era medonho! Aí não moravam os morcegos, os mochos, as corujas, nem as demais aves sinistras, lúgubres e agourentas, que costumavam habitar os lugares funestos; nada que significasse vida; nada que fizesse persuadir, que de fora existia um mundo povoado. Aí não podiam nutrir idéias de ventura, a imaginação sucumbia ao lúgubre aspecto do nada; e aquelas paredes sepulcrais pareciam dizer ao ente que lá estava: infeliz, cuida da morte! (1989, p. 112)

No trecho citado, uma garganta terrível se apresenta como elemento incontrolável e sugere que a força irresistível, que atrai e ao mesmo tempo aponta a destruição, incorpora uma ambiguidade que é central à forma de $O$ Escravo. O leitor é transportado a um mundo que se apresenta selvagem, primitivo, ainda não dominado, "em achadas perigosas, em espiral" (p.111), entendidas como a inexistência de caminho, no estado selvagem e como aquele que está tudo para se fazer. O narrador ainda o define como o nada, em total ausência de vida, destoando da casa de Maria, luminosa, com jardim florido e cheirando a frescor.

A imagem da montanha invoca o poder indiscutível do mundo natural, representa a ideia da atemporalidade que constrata com a condição mortal do homem. As leis reais do mundo estão na natureza onipotente, cuja verdade e autoridade irrefutável é a morte. A imagem de cadeias montanhosas implica um mundo de caos e desordem, mimetizado na irregularidade da topografia das montanhas. Encontrar-se vagando pelas montanhas significa 
estar fora da sociedade, dependente de recursos naturais e suscetível às vicissitudes da vida selvagem. Por outro lado, escalar a montanha, como faz João, sugere a busca humana por espiritualidade, a procura de uma revelação.

Concentrado na tarefa de projetar valores culturais sobre a natureza, o narrador investe em cenas que envolvem grandes ângulos descritivos, a fazer desse tipo de abordagem um estilo. Assim, o quadro da paisagem de abertura do romance é introduzido por meio de uma perspectiva aérea, como quem quer partir do alto, e, em seguida, desce acompanhando a trajetória da ribeira à nascente com seu salto para o passado; não obstante, a natureza da montanha é introduzida para reforçar a ideia de amplidão. O monte sobre o qual se situa a casa de Julia nao é escolhido por acaso. O ponto de vista do narrador, a visão a partir de um olhar pelos horizontes, permite avaliar a beleza natural da paisagem de um ângulo privilegiado, para descrever as cenas fatídicas de violência, estupro e morte. A natureza em fúria, terrível e medonha se apresenta como imagem de inferno, "charco", "pavoroso lugar" que matará a bárbara Júlia.

Ora, se o espaço é a representação física e psíquica do ser, Júlia recusa-se a ser o agente subalterno da hegemonia, o que a torna um monstro, em oposição a Maria que é o tudo o que precisa ser afirmado, ou seja, a alienação conduz a personagem Maria a um estado de despersonificação, inserindo-a como um ser estranho em seu meio, e estrangeiro em seu próprio país. Ambas, personagens-natureza, não se opõem apenas porque representam religiões, línguas, culturas e civilizações diferentes, mas por representarem interesses antagônicos. Nesse sentido, a valorização da natureza da casa de Maria em detrimento da outra opera na valorização do 
híbrido pela voz narrativa. Além disso, prevalece na composição dessas personagens a estética romântica, em cuja criação artística "nem tudo é humanamente belo, que o feio existe lado a lado com o belo, o disforme junto do gracioso, o grotesco a par do sublime, o mal simultaneamente com o bem e a sombra com a luz". (HUGO, 1995, in: GOMES: 1944, 68). É o jogo de contrários que chega à Arte na sua dimensão humana, segundo Gomes.

Em O Escravo (1989), a morte encontra-se em grutas sepulcrais horrendas:

Aquele antro era medonho! Aí nao moravam os morcegos, os mochos, as corujas, nem as demais aves sinistras, lúgubres ou agoureiras que costumam habitar os lugares funestos; nada que significasse a vida; nada que fizesse persuadir, que de fora existía um mundo povoado. Ai não podia nutrir-se ideias de ventura; a imaginação sucumbía ao lúgubre aspecto do nada; e aquelas paredes sepulcrais pareciam dizer ao ente que lá entrava: Infeliz, cuida na morte! (p. 112).

A cena projeta a personagem Júlia no espetáculo espantoso da sua herança, faz com que João tome conhecimento de sua mãe, de sua história e depois, atira-se no abismo terrível, de cima de uma montanha. O abismo é, também, uma descrição de seu interior. Estilisticamente, os adjetivos tornam-se macabros, porém não menos poéticos, se compreendidos numa estética de terror e de implicações discursivas-ideológicas, que emprega estratégias de deformação da imagem do espaço natural de Júlia, em tensão e contraste com 
à do espaço natural de Maria.

O monstro gargantuesco se refere à dicotomia entre o colonizador e o colonizado. Funda-se na ideia do inculto, que ocupa posição inferior na escala de valores que o narrador construiu. A utilização de um espaço natural de horror para recriar os negros africanos comprova a preferência pelos hábitos racionais europeus ao instinto rudimentar do nativo. As técnicas narrativas que associam deformação da carne e dor foram recursos utilizados para opor-se às questões de ideais e valores destacadas na figura de Maria que, apesar de ser africana, se apresenta mestiça: hibrida em pele e costumes.

Essa imagem apocalíptica desorganiza o sujeito e seu espaço natural como num ritual de preparação da morte que se avizinha, e cuja presença desanda em mal metafórico, que transforma o ambiente em negativo pelo demoníaco, pois neste a destruição e morte se sobrepõem, simbolicamente. O narrador, no capítulo XX de O Escravo, intitulado "A Sepultura", proporciona ao interlocutário a paisagem, embaraçada pelo escuro perfeito, redemoinhos e o jogo da claridade dos relâmpagos "é o trovão que muge ao longe" (1989, p.153). A natureza física zoomorfizada produz a sonoridade que atua em conjunto com a visão, e o narrador diz ouvir a viajanteescrava Luíza na sua caminhada pela sombra da morte:

A trovoada que se anunciava rebombando a uma distância imensa, já a pino sobre a ilha de São Tiago, provoca com seu estampido o eco das montanhas: - já estala, brame, e rola-se estrepitosa por sobre as nuvens, que se fendem, e se despedem à terra raios de fogo e água! 
Orai pelo viajante, que a tempestade apanhou no meio da selva. Orai, porque ele caminhará léguas e léguas sem encontrar o convento hospitaleiro - a choça do camponês - a morada do couteiro, onde possa esconder-se à fúria da borrasca! Oh! Sim, orai, porque neste país ele terá que percorrer campos imensos, achadas sem fim, antes de encontrar tecto que o abrigue: terá que subir às cristas dos montes, de descer ínvias e escarpadas rochas, de contínuo atemorizado pelo precipício, que se mostra a seus olhos, como esperando o resvalar de um pé para o tragar! Ameaçado pelas pedras que a chuva desliga do cume das rochas.(1989, p. 153-4)

A natureza suspira e geme, juntamente com o narrador, e conjugados, discurso e sonoridade, ao modo de uma ladainha religiosa preparam o espaço do trágico de $O$ Escravo. Os olhos do narrador caminha pela escuridão, apreende a realidade e parece esperar a morte que chega silenciosamente, sem absolvição. A morte, assim como a dor e a desesperança entranham-se na natureza da paisagem narrada, bem como no sujeito-escravo dilacerado. Tal qual Luiza, o mundo ao redor tornara-se apocalíptico, desvelando, porém, os olhos da feiticeira Júlia e a caverna entulhada de pedras.

Salta aos olhos do leitor a realidade humana e trágica do quadro, pois todos buscam pelo alívio de sofrimentos. O narrador envolve os corpos dos escravos João e Luíza à luz natural do relâmpago em contraste com a luz artificial da lanterna a clariar as feições do cadáver de João, corpos inanimados e a montanha parece uma única alma adormecida, enquanto os contempla em meio às sombras compactas, pois o luar adentra à gruta. $\mathrm{O}$ espaço passa por 
um processo de diluição, as pedras escondem para sempre o lugar da sepultura dos escravos.

O grotesco aparece na linguagem por meio do desfecho final da cena: "Os corvos acabaram de consumir o cadáver da feiticeira, cujos ossos, talvez alguns, ainda hoje se encontrem disseminados pela base do monte" (1989, p.155). Resulta, em humanização do espaço, em que o homem se torna elemento do ambiente. O ambiente transformado como tudo aquilo que procede do exterior torna-se funcional, movendo-se com o enredo, e se compatibiliza como um todo coerente e integrado à ação. Observa-se, também, que o narrador prepara nesse espaço o entrecho trágico, inserido internamente no contexto patriarcal-escravagista do seu tempo. O título do romance metaforiza, nesse sentido, a duplicidade integrada à cadeia da vida e da morte.

\section{- Espaço Social}

O espaço social ${ }^{3}$ em $O$ Escravo corresponde à estrutura da sociedade cabo-verdiana da época, subdividida entre não escravos e escravos. Nele, as personagens se movem no passado, recordando espaço e tempo, entretanto, desafiam-nas pelos atalhos que as conduzem: há não escravos

\footnotetext{
3 Para o estudo do espaço social na obra O Escravo dialogou-se com a pesquisa de dissertação de Alberto Lopes (2010) da Universidade do Porto.
} 
brancos e mestiços, como o bispo, Lopes, os militares - José Joaquim, Aleixo, Carvalho, Cláudio Pimentel e a sua família; e, há escravos que, por sua vez, incluem também aqueles que deixaram de o ser. Note-se a seguinte passagem que o narrador colado ao protagonista João diz:

[...] a liberdade?! De que me serviria? Tirar-me-ia ela de sobre a fronte o ferrete da ignomínia que o destino ali imprimiu ao meu nascimento? Tirar-me-ia a liberdade o olvido do meu passado? Não; porque as vossas leis tiram ao liberto as prerrogativas que concedem ao homem nascido livre. (1989, p. 31)

Observa-se essa separação espacial entre os interlocutores sociais, vinculada as suas habitações, seus trabalhos ou lazer. Em relação ao aspecto da habitação, a narrativa mostra que a casa é o espaço de Cláudio Pimentel e sua família, e as choças, reservadas às personagens como Luiza, Domingos, Júlia e João.

Cabe ainda explicitar a diferença entre o espaço de habitação, reservado aos escravos domésticos, e a senzala, onde habitavam os escravos para o serviço mais pesado. Na narrativa, a personagem Luiza tem acesso ao interior da casa, tanto de dia como à noite, porém apenas como espaço de trabalho. O narrador projeta João a observar o quarto da protagonista "em frente da casa" (1989, p. 49), por cima de um muro, pela janela onde o raio de luz penetra na cortina anteposta e em cuja vidraça a sombra de Maria aparece acompanhada do som de um piano. 
O quarto como espaço de representação do interior da personagem compõe-se simbolicamente em formas e objetos, ora revelados por fora, ora revelados por dentro, num jogo de representação da significação social e de valores europeizados imputados à personagem. O narrador também oferece a cena, acoplado aos olhos da interlocutora Luiza, no fundo do quarto, sentada numa cômoda com um espelho que serve de reflexo à ação que irá se delinear.

Esta casa do batuque, objeto de uma breve descrição é um espaço social de grande importância para o grupo dos escravos. O lazer é a sua função mais visível: espaço de música, de dança e de namoro (até pela sensualidade dessas manifestações), o batuque é também um espaço em que os mais velhos (como Domingos ou Júlia) ou os mais instruídos (como João, que declina o convite) podem contar histórias. Por aí se percebe como estas reuniões podiam funcionar, também, como espaço de desabafo dos escravos ou de tomada de consciência da sua condição de explorados.

As mudanças do ato de ver asseguram à narrativa, simultaneamente, sua multiplicidade e seu desenvolvimento. As deslocações das personagens desdobram-se pelo pensamento, fazendo aparecer, a partir de espaço da realidade, outros espaços imaginários que se encaixam nos primeiros. João e Luíza veem através de visões subjetivas, num jogo de impossibilidades de total visibilidade, pela janela ou pelo espelho, objetos que surgem pelo discurso indireto do narrador, integrando-os no fluxo da narrativa. Era necessário ver, mesmo que subjetivamente, para que o leitor permitisse sua condução e a ação tivesse prosseguimento. 
O sentido da visão aguça-se nas evocações discursivas juntamente com outros sentidos, que interferem e conduzem o espaço a constituir-se como corpo textual. Assim, unem-se sons, vozes, visões, sensações táteis que, ao passarem pelo crivo do narrador, se incorporam como impressões imagéticas da protagonista Maria, mais concretas e vivas, como se pode denotar no capítulo X, quando o narrador conduz o leitor ao quarto da protagonista:

Maria cessou de escrever; correu com a vista as expressões que traçara; e, como mais sossegada de espírito, escondeu o caderno - que era uma espécie de registro, onde lançava as cartas com destino a seu pai - depois agitou com força a campainha. Luiza obedeceu ao metálico som que a chamava: entrou; e - enquanto tratava de dar à luz aquela melancolia que tanto convida ao repouso - Maria, despindo o roupão, subiu ao leito para de todo se entregar às delicias de um sono ameno. (p. 91)

E João aproximara-se do leito da virgem; e tanto, que podia aspirar o hálito dela... notar-lhe o sereno arfar do seio. Ela deitada, não completamente sobre o lado direito, conservava a dextra debaixo da face. Seu braço esquerdo, ao sair do abrigo do lençol, empuxava este de modo a deixar patente a extremidade superior do peito. Um dos seus pequeninos pés havia repelido a cobertura, e colocara-se de maneira, que parecia querer espreitar as ocorrências, através da meia, que era tão fina que em nada lhe alterava o esmero da forma. Os olhos, não completamente fechados, reflectiam por entre a pequena abertura que lhes devisava - um fulgor de lapidado diamante preto. Finalmente, a seus lábios prendiamse interessante sorriso, que brincava sem dúvida com um fagueiro sonho da virgem. (1989, p.94) 
Num primeiro momento, o narrador apresenta Maria exercendo ação consciente sobre os objetos numa exposição de motivações e crises íntimas: toca piano e escreve uma carta ao pai ausente, expondo os perigos e a saudade; num segundo momento, deixa-a envolvida no espaço do desejo, "na mudez da noite", com a "débil luz do candeeiro" verde transparente, num estado de inconsciência: despe o roupão, arfa serenamente os seios deixados à mostra pela extremidade superior da camisola, os pés pequenos ${ }^{4}$ através da meia fina.

Luiza ocupa esse espaço, numa posição de inferioridade: depois de deitada Maria, a escrava sentava-se: “(...) em um pequeno degrau aos pés da cama, para aí esperar que sua senhora dormisse" (ALMEIDA, 1989, p. 91).

Quanto ao trabalho, Luiza, ser feminino, deve velar o sono da protagonista, correspondendo ao espaço do interior da casa. Observa-se que o trabalho de João, ser masculino, corresponde ao exterior, ao jardim da casa. Não há nenhuma outra referência espacial sobre o trabalho das demais personagens. O quarto, que anteriormente ganha significação de "espaço forte", rompe-se com a invasão do masculino, permitindo a subversão enunciativa do espaço.

\footnotetext{
${ }^{4}$ A imagem simbólica da beleza imperial, da delicadeza e do prestígio de Maria reside em seus pequenos pés. Segundo Koda (2000, p. 151), esse fetiche advém dos chamados pés de Cotus, formados pelo atrofiamento dos pés das mulheres da sociedade aristocrática chinesa enrolados por faixas apertadas durante a infância com objetivo de mantê-los pequenos. $O$ costume iniciou-se no século XIII e permaneceu até a vitória dos comunistas de Mao-Tse-Tung em 1949.
} 
Os interlocutores desvinculam-se da realidade objetiva, ressaltando aspectos restritos às exterioridades, tais como o desejo. Torna-se espaço existencial que se impõe, permitindo revelar imagens restritas ao mundo interior dos protagonistas. Nenhum outro espaço pode conferir maior densidade às vontades humanas, portanto, tem-se uma visão privilegiada de suas consciências em face do universo de efabulações que habitam o sono e o sonho. O quarto, espaço fechado, traduz em linguagem simbólica as personagens aos seus sentimentos, sensações e pensamentos de uma vontade que se desejaria viver, porém, no momento em que se desperta, a realidade externa não permite mais os sonhos, revelando a impossibilidade da relação amorosa entre João e Maria. O espelho encontra-se sempre no quarto, todavia surge na matéria diegética, subordinado a um sujeito-espectador Luiza, produzindo a eclosão de cenas dramáticas.

Em relação aos espaços de diversão, percebe-se o passeio existente no exterior da casa de Cláudio como espaço de lazer para as personagens não escravas, neste caso Maria e Lopes. Aos escravos, o lazer ocorre na senzala, com o batuque, o torno e a contação de histórias, porém, mostra-se permeável, pois, admite-se o acesso de brancos, como o narrador tem o cuidado de explicar:

De feito, encostado ao umbral da porta estava um branco. Havia sido visto pela maior parte, mas a ninguém importou a sua presença, porque não era extraordinário ver brancos espectadores dos batuques; e mesmo alguns tomam neles um não pequeno interesse. (1989, p. 68) 
Em José Evaristo de Almeida a descrição minuciosa do narrador produz submissão à atitude narrativa, cujo espaço é variável e com visão multiperspectivada. O narrador ora se aproxima, ora se afasta, enredando com detalhes miúdos da cena, contornando sensações e analisando as personagens e os acontecimentos.

O espaço da senzala, da dança do torno e das contações de histórias são espaços referenciais da real Cabo Verde no presente da narrativa. As percepções do espaço ativam a disposição favorável ao fluxo de lembranças de escravos e escravos-libertos, guiados pela mão do narrador, que rastrea o lugar, evoca o passado das personagens. $O$ passado das personagens denuncia a escravidão, os maus tratos, o sofrimento dos negros escravos, a humilhação, o estupro e a violência dos senhores proprietários de escravos, intensificando um discurso ético moral sobre a escravidão. Essa multiplicação fiel do espaço escravista cabo-verdiano apresenta uma visão dramática deste ambiente.

A topografia da senzala observada à noite, no momento em que cessam os trabalhos para descanso dos escravos, resguarda a dimensão ativa, pois a visão do espaço vai sendo diluída em história de amor e simbologias, metaforizando as diferenças entre escravos e senhores, amores escravizados e idealizados, negros e brancos, cujas existências estão intrincadas na real vivência da sociedade escravagista de Cabo Verde. Dessa maneira, as descrições auxiliam a criar um conjunto de identidades, leis e semelhanças que definem as personagens e suas práticas sociais, a partir do espaço da senzala. 
Para Osman Lins "o delineamento do espaço, processado com cálculo, cumpre a finalidade de apoiar as figuras e mesmo de defini-las socialmente de maneira indireta" (1976, p.76).

O espaço da senzala localiza-se na Vila da Praia numa "casa pouco decente, mas com dimensões próprias a deixá-lo respirar à vontade" (1989, p.61). A casa da senzala é apresentada em breve descrição, como rústica pelo reboco de areia preta comparada a cor triste e sombria do local. Esse espaço constitui-se, também, como lazer para os escravos: há a música do batuque; a dança do torno; o namoro - expresso pela sensualidade nas imagens do torno. É também o espaço em que os velhos personagens Domingos e Júlia podem contar histórias.

A luta de Júlia pela vida, recontada na história da feiticeira, é empreendida contra as circunstâncias sociais, econômicas e históricas nas quais está mergulhada. A escravidão e o racismo como fatores históricos que marcaram o século XIX, influi no destino da personagem e cria, no plano do romance, o cenário determinante. A complexidade do romance é circunscrita em força tensiva, de revoltas e iras, o que termina por apontar certa ambivalência ao leitor que percebe as condições da estrutura social do país.

Portanto, além da senzala funcionar como lugar de manifestações culturais cabo-verdianas, as reuniões são entendidas como ambiente de desabafo dos escravos e de tomada de consciência da sua condição de explorados.

A senzala funciona na voz narrativa como meio da comunidade transmitir os seus valores e as suas crenças. A música e a dança são 
elementos centrais do batuque apresentado pelo narrador que salienta o seu aborrecimento diante das características da música, próxima de melopéias africanas bantus: "[...] mas a música! a música era infernal! Sem cadência, sem harmonia e sem gosto, julgareis ter na frente a cópia viva do quadro de Hoghar 'O músico desesperado'. Os sons das guitarras não podiam ouvir-se[...]” (1989, p. 77).

Diferentemente, o canto que a acompanha recebe a aprovação do narrador:

Forma-se a roda: trinta ou mais bocas femininas se abrem e dão liberdade às vozes, que elas possuem de uma extensão a causar inveja ao mais abalizado barítono - mas a música era infernal. Sem cadência, sem harmonia e sem gosto, julgareis ter na frente a cópia viva do quadro de Hoghar. Este acompanhamento compunha-se do bater das mãos sobre os panos, que cada uma passara por sobre as coxas, amarrara junto às curvas, e, com a separação dos joelhos, esticara qual pele em afinado tambor. E nesse bater tinha a cadência toda sua, uma toada para a qual nós não achamos comparação que a explique: - enquanto que uma mão caía com regularidade extraindo do pano sons compassados e secos, a outra fazia ouvir um tremido, uma espécie de rufo, que é onde está toda a delicadeza do xabeta. (1989, p. 77-8)

O narrador refere-se provavelmente ao cimbó (ou cimboa), guitarra monocórdia que normalmente acompanha as sessões do batuque. De acordo com Lopes (2010, p.57), no livro Cabo Verde - Apontamentos Etnográficos (1976, p.52-4), esse instrumento do Oriente foi introduzido em Cabo Verde, 
através dos escravos. Trata-se de uma espécie de rabeca, formada a partir do bojo de uma cabaça ou da calota de um coco, cuja abertura é coberta com uma membrana de pele de cabrito ou carneiro, curtida artesanalmente, servindo de caixa de ressonância. Sobre ela aplica-se um "pescoço", feito de um bocado de madeira, que termina por uma cravelha, a que se prende a única corda (feita de crinas torcidas), depois de a passar por um cavalete. Faz ainda parte de instrumento um arco, com que se fricciona a corda vibrátil.

Conforme Luis Romano (1966), o batuque introduziu-se em Cabo Verde com a presença de famílias bantas e congêneres e, com ele, diversos ritmos afros "desenfreados", contribuindo para a formação das danças das "coladeiras" movimentadas: "Sob o tantã dos batuques, apitos, saltos coreográficos e trejeitos voluptuosos, numa apoteose do subconsciente em hino à embriaguês de escravos livres, por instantes do pesadelo do despatriamento e do banzo" (p.139)

A dança do torno executada na senzala é o que o narrador destaca e a que se liga:

Este alarido convida uma delas a saltar para o meio do círculo, o qual se vai estreitando a ponto, que mal deixa o espaço preciso para as evoluções da rainha do momento. Vêla-eis então medir o compasso com o corpo, cingir o pano à cintura, juntar-Ihe aí as pontas em nó, que desata logo, com uma indolência perfeitamente representada. Vê-la-eis dizemos - torcer-se, requebrar-se, impor aos quadris movimentos - demorados no princípio - mas que vão progredindo, exaltando-se à proporção que — de mais em mais 
- se acelera o compasso do xabeta. E quando o ente preferido - aquele sobre quem ela emprega os seus olhares - grita com um entusiasmo de possesso ripundá xabeta oh! Então ela despe a modéstia com que até ali se ornara; o xabeta assume um crescendo furioso; e ela - amarrando o pano de maneira a deixar esculpidas as formas do corpo levando as mãos umas vezes à cintura, outras ao ar, onde faz ouvir os trincos de seus dedos - olhando alternadamente 0 céu e a terra - ela se inclina, se dobra, se eleva, se torce, se volta, se arqueia, tudo com agitação febril - com transportes frenéticos - com furor vertiginoso - com movimentos tantos, tão rápidos e lúbricos; que julgareis ver nela a lascívia personificada! (p. 78)

Percebe-se que o narrador empreende a apresentação de um ambiente em que a narrativa é suspensa para dar lugar a quadros descritivos que dão visualidades à cena com apelo visual e sensorial saltitando aos olhos do leitor. O movimento da descrição na narrativa é imposto pelos verbos "ver" e "olhar" que produzem a imagem da dança.

A imagem de uma cantoria infernal e da dança, em que o corpo quase se dilacera no frenesi da festa, formam um quadro sugestivo e poderoso, tanto pela exuberância da descrição, quanto pela forte impressão que revela, do registro detalhado,que indica a fidelidade da observação. A transcrição da cantiga, seguida do comentário sobre a língua crioula e a origem etnológica da capacidade de improviso demonstrada pelo negro, termina de encerrar 0 episódio como que em um parêntesis, que se abre na narrativa, para o exercício quase puro do registro documental. 
A descrição opera pelo recurso à expressividade - a dança é como um delírio desesperado, quase sôfrego, em que a ênfase está na variedade da coordenação dos movimentos do corpo -, e pela eroticidade.

É uma passagem em que o autor apresenta o cotidiano dos escravos, seus costumes e festejos, captados vivamente pelo desejo geral de registrar os elementos característicos da vida local. As personagens escravas estão implicadas no espaço do romance e aparecem integrados na trama narrativa.

A imagem viva da dança colabora com o cenário, destacando-se a sensualidade da dança captada pelo narrador de O Escravo:

Luísa começara o torno com a languidez e indiferentismo próprio de que não cura do que está fazendo, contudo através da pálida e sombria luz da sala - fulguravam seus olhares vivíssimos, cujas negras pupilas tomavam uma direcção única - a que mais facilmente as colocava sobre o rosto de João. - Este encontrava os olhares da escrava; e admirado da obstinação com que a Luísa o fixava, quis ver como sempre acontece nestes casos - se a obrigava a volver os olhos para além: conservou, pois, os seus imóveis e fitos sobre os da escrava. Após alguns segundos, João experimentou a influência do magnetismo daquele olhar: a corrente de electricidade estabeleceu-se entre ambos; e ele cedendo ao encanto que o fascinava - vencido por essa atracção magnética que nós, pelo menos, não sabemos explicar, deixou-se insensivelmente aproximar de Luiza. (1989, p. 79) 
O narrador apresenta uma cena de objetividade, como se estivesse em contato direto com o real da senzala, mostrando a unidade e a continuidade daquele espaço de representação. A imagem desse espaço da dança e do batuque sugere o lugar de liberdade dos oprimidos. A vivência da África caboverdiana é relembrada nos tornos, nas palavras crioulas, nas comidas e costumes e respondem a arquétipos de um lugar em suspensão, livre das amarras da escravidão diária.

Diferentemente, porém, da casa de Maria, em que o narrador intelectualizado oferece longos parágrafos descritivos, dando mostra de conhecer a história da Cabo Verde burguesa e mestiça, bem como aspectos geográficos e culturais, em relação à linguagem crioula, o narrador lamenta não conhecer.

- Ó Cacilda, os teus convidados demoram-se bem. Isto disse em crioulo fundo a voz áspera de um escravo, com evidentes sinais de enfado.

Dissemos que lamentávamos não saber manejar a linguagem crioula, quando tratávamos de reproduzir as frases de Luíza; não nos acontece, porém o mesmo no que respeita o crioulo dos homens. O crioulo passado por femininos lábios toma uma expressão doce, agradável, terna e própria a revelar o mimo, a ingenuidade e a meiguice da alma; porém, nas bocas masculinas, ela - não só perde toda a graça - senão que torna-se ridícula, se acaso - com a afectação - o homem busca dar-lhe uma suavidade, que, ainda assim, ele não pode prestar-Ihe. (1989, p.62) 
Essa diferença no processo do conhecimento da linguagem pelo narrador produz e assegura que o sentido nunca é simplesmente mimético e transparente, porque a performace cultural dramatizada no relato entre 0 sujeito do enunciado e o sujeito da enunciação restringe a identidade cultural de Cabo Verde, articulada num espaço exótico e de fetiches, como espetáculos de preeminência "natural"/racial, ou nas palavras de Fanon (1956, p.44):

\begin{abstract}
Esse comportamento [do colonizador] trai uma determinação de objetivar, confinar, prender, endurecer. Expressões como "eu os conheço", "é assim que eles são" e mostram essa objetivação máxima atingida com sucesso... Há de um lado uma cultura na qual podem ser reconhecidas qualidades de dinamismo, crescimento e profundidade. Contra isso temos [em culturas coloniais] características, curiosidades, coisas, nunca uma estrutura". (apud BHABHA, 2005, p.128)
\end{abstract}

Em O Escravo, as ruas são compostas por sinos de igreja, praças, bar e um relógio regulador. Tais elementos constituem-se como referências objetivantes com referências particulares. Todavia, a casa de Maria e da senzala são espaços-macros do romance delimitando a natureza dual: a primeira, espaço de dominação; a segunda, espaço de liberdade "controlada".

A taverna do Tio Tesoura opera como espaço de lazer e traição. $O$ proprietário é um degredado, conhecido pela alcunha de tio Tesoura. Preparando o leitor metropolitano para a cena que vai ler, o narrador esclarece, na abertura do capítulo IX: 
A falta absoluta de botequins, obriga a que na Vila da Praia, certa gente - que não sendo da ínfima plebe, não está contudo nas circunstâncias de entrar na roda escolhida frequente casas a que noutros países de certo fugiria. Não deve portanto admirar que no princípio da noite de 20 de Março do ano a que nos referimos, estivessem - numa das poucas casas interiores pertencentes à dita taverna - alguns sargentos, cabos e soldados, formando grupos, sentados em frente de mesas de pinho, sobre as quais havia profusão de garrafas e copos. (1989, p. 81)

A taberna surge, na narrativa, como estalagem de uma camada social baixa, freqüentada por militares, que, noutras circunstâncias, ali não estariam. O narrador não desevolve de falto uma crítica à falta de estabelecimentos desse tipo em Santiago. Dessa forma, o narrador parece abdicar mais uma vez de críticas aos aspectos que diferenciam a cultura de Cabo Verde e a da metrópole.

A grande quantidade de descrições faz parte do estilo do autor, ocupando longas páginas com detalhes das diversidades culturais da cultura caboverdiana, com o objetivo de apreensão dessa sociedade caboverdiana. Porém, no relato do narrador, percebe-se uma necessidade de potencializar a exploração do negro pela escravatura, ligando-o à condição de sofrimento e à presença dos vilões senhores e aventureiros.

Essa exploração excessiva de sofrimento por todas as maneiras de escravatura realça a dominação do colonizador, muitas vezes, caricata, num esforço de acentuar a realidade da escravidão. A consequência é uma ambiguidade textual e o reforço de uma postura conservadora e hegemônica 
no que se refere às personagens negras e escravas. O narrador acaba por se colocar no centro do sistema político colonial - o da dependência da colônia cabo-verdiana. Ocupa, para isso, um lugar de poder em nome da história vista a partir de uma perspectiva eurocêntrica, mas humanitária. 
ESCRAVIDÃO E RAÇA NO CONTEXTO LITERÁRIO

EUROPEU: O NoIVAdo EM SÃo Domingos E BUG-

JARGAL EM DIÁLOGO COM O ESCRAVO 
Quando encontra a resistência do outro, a autoconsciência passa por uma experiência de desejo... Assim, que passo a desejar, peço para ser considerado. Não estou simplesmente aqui ou agora, selado e coisificado. Eu sou a favor de outro e de outra coisa. Exijo que se tome conhecimento de minha atividade negadora na medida em que persigo algo que não vida... Eu ocupava o espaço. Movia-me na direção do outro... e o outro evanescente, hostil, mas não opaco, transparente, sem estar lá, desapareceu. Náusea.

Há uma procura pelo negro, o negro é uma demanda, não se pode passar sem ele, ele é necessário, mas só depois de tornar-se palatável de uma determinada maneira. Infelizmente, o negro derruba o sistema e rompe os tratados

Frantz Fanon (1976)

O desejo de compreender a inserção de $O$ Escravo no sistema literário de Portugal e de Cabo Verde conduziu a investigação para a literatura europeia no século XIX, com objetivo de buscar ali romances similares que tratassem do tema da escravidão e da questão racial. Nessa busca foram identificados dois romances que antecederam a publicação de $O$ Escravo e, muito provavelmente, foram referências para José Evaristo de Almeida. São eles: Die Verlobung in St. Domingo (Noivado em São Domingos), do alemão Bernd Heinrich Von Kleist, e Bug-Jargal, do francês Victor Hugo. Passa-se, portanto, a comparar esses dois romances com $O$ Escravo, com o intuito de confrontar como foi tratada a temática da escravidão e da raça. 


\subsection{O NoIvado em São Domingos, de BeRnd HeinRich Von KLeist e Bug-Jargal, De Victor Hugo}

O Noivado em São Domingos foi publicado em 1811, na Alemanha. Seu autor Heinrich Von Kleist lançou a obra pouco antes de seu suicídio. O estudo do romance alemão baseia-se na recente pesquisa de Rodrigo Castro(2006) sobre a novela Michael Kohlhaas - a Vitória da Derrota, de Kleist, e no artigo do pesquisador alemão Beil, publicado na Revista Pandaemonion Germeniam, em 2007. Neles situam-se as referências do presente estudo.

Rodrigo Castro (2006) afirma que Von Kleist criou uma obra relativamente pouco extensa durante sua carreira, legando à literatura oito peças de teatro, oito textos em prosa e alguns poemas e cartas. Sua vida foi muito instável: fez-se militar aos 15 anos, abandona o exército pela carreira pública aos 22 anos e, não se adaptando, decide ir para Suíça tornar-se agricultor. Em 1804, publica o seu primeiro texto de teatro na Revista Phobus. A instabilidade profissional e econômica, juntamente com uma saúde frágil e uma vida sentimental agitada conduzem-no para o pacto de morte, aos 34 anos, com a amiga Henriette Vogel, assassinando-a e logo após se suicidando.

Rodrigo Castro (2006) afirma que o sucesso e conhecimento do poeta, teatrólogo e prosador prussiano só ocorreu no século $X X$, após a Segunda Guerra Mundial, em razão da pluralidade e heterogeneidade das 
publicações a respeito de Heinrich Von Kleist, que tornaram complexo e difícil o seu reconhecimento. Todavia, nos textos críticos, o escritor, colocado à margem em seu tempo, conquista destaque dentro do imaginário Ocidental, recriando o "homem impotente, mero joguete de um mundo incompreensível, objeto de um destino incontrolável" (CASTRO, 2006, p.15).

Garantindo a posição do autor na literatura alemã e universal, a crítica dividiu-se em duas grandes correntes, que interpretam a história da noite de São. Domingos. Segundo Beil (2007), uma das correntes classifica o livro como "uma autobiografia espiritual" com propósitos moralizantes e se apoia na ideia de que o romance é estruturado "no modelo historiográfico"; outra o apresenta como um "precursor do drama moderno, com detalhes das causas reais das crises emocionais vividas pelas personagens" (p. 02).

Já o romance Bug-Jargal, do francês Victor Hugo, teve duas versões, em momentos distintos. A primeira edição em 1820, publicada no jornal Le Conservateur Litteraire, quando a llha de São Domingos ainda sofria as tensões e os conflitos da unificação comandada por Boyer; a segunda versão, em 1826, em forma de livro, ocorreu no período em que a monarquia francesa restaurada reconhece a independência política daquela ilha (Omaya, 2009).

Jacques de Cauna, em seu artigo "Les sources historiques de BugJargal: Hugo et la révolution haitienne" (1985), afirma que Victor Hugo apresenta em seu Prefácio a grandiosidade da Revolução Haitiana, feita pelos escravos, transfigurando-a em uma real ameaça ao novo poder colonial que se criava nas Américas. Daí a explicação para tantas crueldades aplicadas para esmagá-la e silenciá-la, e a consequente imagem aterrorizante do Haiti. 
Para Carmiela Biondi (1999, apud Omaya, 2009), Bug-Jargal é o primeiro romance da literatura francesa com um herói negro. Pierrot, o negro escravo bom durante o dia, transforma-se à noite em Bug-Jargal, "com características de Thoussaint: conciliador com a França, como homem preocupado com o povo, chefe respeitado pelos negros, ou seja, como francófilo" (p. 125).

O modelo de herói negro lançado na Inglaterra por Aphara Behn, em 1688, baseia-se no estereótipo de Oroonoko, jovem herói negro, da Colônia de Suriname, portador de beleza estonteante, caráter ilibado e respeitado por todos. Essa construção de personagem - negro bom e escravo rebelde repetiu-se em muitas obras europeias. Porém, em Bug-Jargal a pecularidade está nos detalhes, pois há muitos adjetivos e descrições que remetem a "uma poética do excesso" (ANTOINE, 1992, p.91, apud, Omaya, 2009, p.126).

Além dos textos de Jacques de Cauna (1996) e Maria Helena Oyama (2009), toma-se como referência os estudos sobre Bug-jargal a pesquisa de Claúdia Veiga de Almeida, quem primeiramente relacionou o romance de Victor Hugo ao de José Evaristo de Almeida (2009).

\subsubsection{As DuAs NaRrativas Europeias}


Tendo em vista a dificuldade de acesso às obras de Heinrich Von Kleist e Victor Hugo, em função de suas raras traduções e edições, resumemse aqui as tramas em questão e, posteriormente, passa-se a comentá-las.

O Noivado em São Domingos, de Heinrich Von Kleist, é uma narrativa curta de um único capítulo e passa-se em Port au Prince, na ilha de São Domingos, região colonial da França na América Central. O texto remetenos à luta pela libertação dos escravos do lado francês do atual Haiti, ocorrida entre 1793 e 1803. Os episódios criados na narrativa são análogos àqueles de fato ocorridos durante a Independência no Haiti, a revolta dos escravos e a política imperial francesa nessa parte do mundo.

A diegese do romance conta com um narrador heterodigético e tem por protagonista Gustav Von der Ried, um oficial suíço fugitivo, branco, que numa noite chega à casa de Congo Hoang, o mais impiedoso chefe dos revoltosos negros de San Domingos, em busca de abrigo e ajuda. Encontra Babekan e Toni, mestiças, que tentam convencê-lo de que estariam sob ameaça do ausente Congo Hoang, por serem simpáticas aos brancos.

Em razão das longas conversas e histórias, Gustav vai adquirindo confiança, aceita ficar e dormir num quarto da casa. Toni lava-lhe os pés e Gustav, enamorado, começa a ver certa semelhança entre ela e a noiva Mariane Congreve. Sente-se atraído por ela e acaba por dormir com Toni. Na manhã seguinte, fica-se sabendo que tudo não passava de um plano arquitetado pela mãe de Toni para atrair Gustav e entregá-lo a Congo Hoango. Apesar de argumentar a favor da inocência de Gustav, Toni cede ao plano para não se opor à família. 
Porém, Toni, transfigurada pelo amor, converte-se de insensível agente de sedução, a salvadora de Gustav. Prepara um plano que os salve, pois Congo Hoang volta mais cedo e Gustav ainda não sabe do complô contra ele, armado por Babekan e Congo Hoango. Toni envia uma carta ao grupo de refugiados, que se encontrava escondida na floresta. Amarra-o na cama, esperando convencer o pai de que não traiu sua confiança. Assim, a protagonista consegue manter a família de Gustav a salvo e dominar Congo e Babekan. Stromli, o amigo de Gustav, refugiado suíço, chega a casa no momento em que a crise familiar vai ocorrer e consegue livrar Gustav. Tudo parece acabar bem, mas Gustav, acreditando ser traído, atira em Toni impulsivamente, mas quando descobre os verdadeiros motivos da ação de Toni e o erro de sua descrença nos sentimentos dela, sente-se culpado e, desesperado, se suicida.

$\mathrm{Na}$ cena final, os dois amantes mortos são levados em caixões com Stromli, rumo à Santa Lucia, onde cinco dias depois o refugiado suíço lutará pela causa dos brancos e, ao voltar à sua pátria ergue um monumento a Gustav e Toni.

Já a narrativa de Bug-Jargal, de Victor Hugo, é composta por cinquenta e oito capítulos, subdivididos em três partes. Na primeira parte, o narrador homodiegético rapidamente apresenta a história do capitão Leopoldo d'Auverney num acampamento militar, nas fileiras da guerra contra a Inglaterra, e a narrativa passa a ser contada pelos dois amigos: Leopoldo e Tadeu. Esses narradores autodiegéticos rememoram a história de Bug-Jargal e a perda da família. O capitão lembra a Revolução de São Domingos, da qual fizera parte 
com Tadeu. Os soldados, envolvidos na lembrança, pedem ao capitão que reconte a história de Bug-Jargal.

No capítulo IV e V, o capitão relata sua trajetória para a Colônia: havia nascido na França e jovem foi para São Domingos se casar com Maria, sua prima, filha de um rico proprietário de terras, com oitocentos escravos, submetidos à insensibilidade de um déspota. Este mantinha também em sua casa um escravo anão, mestiço, tratado como "bobo da corte", pois sua função era divertir a todos, mas na ordem social indígena, era um feiticeiro, muito perigoso. Habribah, como era chamado, é descrito como um animal, vindo da Jamaica, para servir aos senhores na casa grande.

O casal costumava encontrar-se no jardim. Um dia, o jardim foi pisoteado e Maria ouviu uma pessoa cantando e tocando guitarra, dizendo o nome dela. Contou para o noivo e resolveram ir à noite ao local para descobrir o autor da façanha. Ao chegar lá, ouviram a música e Leopoldo se bate com o cantor, travam uma luta, mas o cantor consegue fugir. O homem era forte $\mathrm{e}$ alto, nu da cintura para cima, o que era comum aos escravos. Posteriormente, os noivos ouvem novamente a musica em espanhol, como um lamento cuja letra tratava do amor de um negro por uma branca. Numa tarde, Leopoldo ouve gritos de Maria e, quando chega ao local, encontra um jovem negro muito alto, que luta contra um crocodilo para defender Maria. Leopoldo mata a fera, mas o escravo Perrot o repreendeu pela ação, parecendo ansiar pela morte.

Para compensar o escravo pela vida de Maria, Leopoldo convence o sogro a dar-lhe liberdade, assim que o encontrassem. Porém, Habribah denuncia ao proprietário que um escravo estragava as suas roseiras de 
estimação e, ao tentar castigar o escravo, o proprietário é detido por Perrott. Sua atitude custa-Ihe a prisão e a perda da liberdade. Mas, Leopoldo com a ajuda de Tadeu, alferes da prisão, mantém amizade com Pierrot, visitando-o diariamente. Finalmente, Leopoldo consegue perdão para Pierrot, todavia, chega tarde, pois só encontra um bilhete de agradecimento e uma mensagem em código dizendo da fuga.

O capitão relata que naquela altura todos os seus olhares estavam voltados para a amada, além de realizar pequenas ajudas aos escravos, escondido do tio. Descobriu, então, o decreto político da colônia de 15 de maio, que dava direitos iguais aos escravos livres. Ao tentar defender tal decreto gerou brigas e um duelo com um rico plantador mestiço.

No dia do casamento há uma rebelião de escravos e o noivo, por fazer parte da milícia, dirige-se ao palácio do governador. Várias posições contra o movimento são expostas no relato e descartadas: o governador propunha armar os mulatos contra o movimento, outro plantador, negrófilo declarado, propunha que matassem e empalassem os escravos que ainda não estavam no movimento, pois tinha exposto a cabeça de cinquenta escravos na revolta anterior.

A rebelião invadiu a planície do Acul, onde estava a propriedade do tio de Leopoldo. Os negros sitiaram o forte com os plantadores e suas famílias refugiadas e aguardaram Pierrot, que apareceu e levou Maria. Leopoldo é atacado e fica desacordado. Ao recuperar-se, Tadeu conta-lhe que os rebeldes fugiram, destruíram a plantação e mataram o tio dele, e também o anão Habribah, pela sua infidelidade aos seus iguais. 
Os rebeldes se dividiram em grupos: Maribon e Buckman, os dois mais violentos, e Mourme-Rouge, liderado por Bug-Jargal. Várias lutas travaram-se, em que o exército colonial era derrotado. $O$ governador encaminhou Leopoldo à frente do exército, com Tadeu. Às margens do rio Grande são surpreendidos pelos rebeldes da liderança de Pierrot. Tadeu relata que havia lutado com Pierrot dentro do rio e que ele o reconheceu e poupouIhe a vida

A segunda parte que vai do capítulo XXV a XLVI compreende o período em que Leopoldo fica como prisioneiro do líder negro Biassou. Um grupo de negras griotas - contadoras de histórias da cultura oral africana tenta torturá-lo com brasa, mas um feiticeiro leva-o para Biasson. Assiste-se a uma cerimônia dirigida pelo feiticeiro e ao discurso de Biasson incitando à luta. Chega a notícia da morte de Buckman, e Biasson dá a Leopoldo a chance de vida, se escrevesse uma carta pedindo trégua aos brancos, dando-Ihe prazo até a manhã seguinte. Entregue ao grupo de Mourne-Rouge, Leopoldo é resgatado por Pierrot, que afirma ser Bug-Jargal. Pedem a liberdade a Biasson que a cedeu, contanto que Leopoldo voltasse pela manhã. Pierrot entrega-lhe Maria. Leopoldo volta para Biasson, mas não escreve a carta. É então, entregue ao feiticeiro que se revela Habribah, assassino do tio. Lutam e caem num precipício. Leopoldo é salvo por Bug-Jargal. Apresentam-se várias descrições das contradições políticas da época e os soldados conjecturam sobre os acontecimentos na Colônia.

$\mathrm{Na}$ terceira parte, entre os capítulos XLVII e LVIII, Bug-Jargal descobre a traição de Biasson e tenta chegar ao campo de guerra dos brancos, antes que matem os negros prisioneiros. Bug-Jargal chega a tempo, mas é 
fuzilado. O narrador, então, relata que o capitão foi denunciado como conspirador da República, mas o general pediu à Convenção Nacional a gratidão pelos seus feitos, pois havia lutado até a morte em combate.

\subsubsection{A ESCRAVIDÃo Nos RomANCES}

Como o propósito é analisar o tema da escravidão e da raça nas obras aqui comentadas, que se caracterizam por expor conflitos históricoculturais e raciais, tomam-se as categorias estruturais da narrativa para melhor perceber como as temáticas constroem-se nos romances.

\subsubsection{Tempo E Espaço No Tecido Romanesco Das Obras}

O título da obra O Noivado de São Domingos informa sobre o lugar em que a ação transcorreu: trata-se de Port au Prince, do lado francês da llha de São Domingos, lá, quando os "negros matavam os brancos, vivia um terrível preto, cujo nome era o Congo Hoango" (1992, p. 145). 
O nome "São Domingos" era dado à ilha antes de sua divisão em dois países, o Haiti e a República Dominicana. A Independência política do Haiti partiu de movimentos organizados por quilombos. Participaram do movimento de libertação líderes como o africano Francois Makandal, cuja estratégia de luta era queimar plantações e casas de colonos. Ao líder e escravo fugido, Buckman Dutty, é atribuída a realização de uma reunião entre vários líderes, na qual se decidiu pela morte de todos os brancos da ilha (OYAMA, 2009).

Esse episódio, a que se refere Heinrich Von Kleist no romance, tem foco na importância econômica e estratégica da região e na redefinição das relações internacionais na Europa, no entre séculos, e foi inflamado pelas Revoluções Americana e Francesa.

A narrativa é ambientada em acontecimentos históricos que sustentam a trama engendrada pelo escritor: passa-se na época das queimadas de plantações quilombolas, movimento liderado por Dessalines, e o episódio central é a luta dos negros haitianos contra o regime escravocrata.

Congo Hoango foi, no delírio geral da vingança que chamejava naquelas plantações com as imprudentes medidas de Convenção Nacional, um dos primeiro a pegar a espingarda e, pensando na tirania que o havia arrancado de sua pátria, estourou com uma bala a cabeça de seu senhor. Incendiou a casa, onde a esposa do mesmo e seus três filhos e o resto dos brancos da colônia se haviam escondido, destruiu toda plantação, a qual os herdeiros, que moravam em Porta au Prince [...] (KLEIST, 1992, p.145, grifos nossos) 
A ênfase histórica é reforçada por nota explicativa ao leitor acerca da Convenção Nacional, promulgada em 1794, em Paris, dando a liberdade e igualdade aos negros habitantes da parte francesa da ilha. Porém, os colonialistas brancos preferiram lutar a reconhecer os direitos políticos dos negros.

A narração, do ponto de vista temporal, é posterior à diegese. A situação colonial é explicitada, envolvendo os negros, os senhores franceses e os mulatos. Tal acontecimento serve para enfatizar as questões políticas e o clima de instabilidade da ilha de São Domingos.

Rodrigo Castro (2006, p.38) salienta que a luta pela liberdade na ilha São Domingos não era apenas a luta dos escravos, mas de colonos, grandes plantadores, que queriam o fim do l'exclusif, lei que centralizava o comércio da colônia, impedindo-a de comercializar com outros países. Queriam o livre comércio com a região e com outras metrópoles. Os homens livres, incluindo mulatos e negros libertos, também, reivindicavam liberdades de direitos políticos e sociais com relação ao poder branco. Contudo, os colonos se recusaram a garantir-lhes os direitos que os levassem a competir no âmbito comercial, o que provocou revolta por parte dos mulatos. No âmbito social, a população vivia as contradições geradas pelo racismo e pelo preconceito.

Há uma linha cronológica nas causas e consequências tecida na diegese, a fim de esclarecer os fatos, para que o leitor se envolva, pleno de informações, sobre os acontecimentos da própria história de São Domingos, de informações constatáveis e admissíveis, acompanhadas de explicações: 
E qualquer um sabe que, em 1803, quando o general Dessalines avançou sobre Port au Prince, com trinta mil negros, todos os que tinham pele clara tentaram defendê-lo. Pois ele era o único ponto de apoio de poder francês na ilha, e se caísse, todos os brancos que ali morassem estavam perdidos. (KLEIST, 1992, p.146)

A narrativa ambienta-se no levante de escravos ocorrido na ilha, com personagens históricas, como Dessalines, ex-escravo negro, imperador do Haiti, que depois da partida dos franceses aparece na luta ao lado no negro Congo Hoango. Assim, o narrador situa os acontecimentos históricos, localizando-os geograficamente - Port au Prince; ilha francesa de São Domingos; Fort Dauphin; Índia Ocidental; Estrasburgo, Europa-; e cronologicamente: "imprudentes medidas da Convenção Nacional" (p.145); "general Dessalines” (p.146);“em 1803”, (p.146); "em 1795” (p.163).

As referências de lugares conhecidos investem, pois, na "realidade do espaço". A alusão repetida a eles torna-os costumeiros, servindo para estimular a crença do leitor no mundo representado.

As "determinações temporais da instância narrativa", conforme esclarece Genette (1995), são manifestações importantes de significação, pois respondem à distância temporal, o que a ocupa e a anima (p. 215). A fixação histórica determina o momento das revoluções e constituem-se como quadros ordenados temporalmente. 
Pouco depois de instituir a temporalidade da narrativa, já na casa de Congo Hoango, o narrador heterodiegético, de focalização externa, afasta-se para que as personagens passem a lembrar acontecimentos ligados aos episódios históricos. Tais acontecimentos antecipam a narrativa, com base no que as personagens se lembram, recriando-os, em face da situação do presente e do temor do futuro.

A primeira lembrança registrada ali, na casa, é da personagem Babekan "com a autoridade de uma velha" contou a história do nascimento de Toni, sua filha:

A mãe tomou a palavra e disse que Toni nascera há quinze anos, durante uma viagem com a esposa do senhor Villeneuve, seu antigo patrão, [...] seu pai era um rico comerciante de Marseille chamado Berthand e por isso ela se chamava Toni Betrand. O senhor Berthand, segundo notícias bastante seguras que recebera, não estava mais na França. $O$ seu espírito ambicioso e progressivo, falou, não se adequava ao circulo das atividades burguesas; com a eclosão da revolução, ele se misturou às ações públicas e, foi, em 1795, com uma legação francesa para a corte Turca[...] nunca esquecerei o juramento que ele, atrevidamente, fez diante de mim, uma febre biliosa foi a conseqüência disso e logo depois sessenta chicotadas que o senhor Villeneuve mandou aplicar, cujas conseqüências são uma tuberculose até hoje. (KLEIST, p. 153-54)

O relato evidencia argumentos sobre a cor mulata da mãe e mestiça da filha, e servia para convencer o protagonista Gustav de que estariam 
ameaçadas pelo agora ausente Hoango, de quem eram vítimas, bem como pela relação delas com as ideias da revolução.

O segundo relato ocorre numa sequência linear no tempo:

O delírio de liberdade que havia invadido todas as plantações levou os negros e crioulos a romper as correntes que oprimiam e à vingança contra os brancos por causa de muitos e censuráveis maus-tratos feitos por alguns malvados membros daquela raça [...] estranho e pareceu o feito de uma jovem. Essa moça, de raça negra,estava sofrendo de hepatite, justamente na época da eclosão da revolta, a qual duplicou a miséria na cidade. Três anos antes ela havia servido como escrava a um plantador de raça branca, que a maltratava, já que não havia mostrado disposta a realizar seus desejos, vendendo-a depois a um plantador crioulo. Como então, no dia seguinte da revolta geral, a moça soube que o plantador, seu antigo dono, havia fugido da ira dos negos que o perseguiram para o estábulo de madeira próximo dali, ela pensando naqueles maus-tratos, mandou o seu irmão até ele, convidando-o a pernoitar em sua casa. O infeliz, que não sabia que a moça estava indisposta, nem de que doença ela sofria, foi e se abraçou com ela [...] mas mal tinha passado meia hora de caricias e ternuras na sua cama, ela repentinamente levantou-se, com uma expressão de ira selvagem e fria e falou: você beijou uma pestilenta, que traz a morte no peito. Vá e espalhe hepatite em todos os seus semelhantes! (1992, p.155-56)

Essas demarcações estabelecem o vínculo com o passado rememorado e o futuro temeroso e incerto. A sucessão do tempo é feita de forma minuciosa, com diversos marcadores temporais: 
- “Já era quase meia-noite, pegou a luz" [..] (p.156)

- "Logo em seguida a moça se havia levantado" [...] (p.158)

- "Logo que amanheceu por completo"[...] (p.161)

- "Toni, diante dos olhos, em poucos minutos" [...] (p.169)

- "[...] ficou feliz em alcançar, cinco dias depois" [...] (p.180)

- 'E, ainda em 1807, podia se ver.”[...] (p.180)

O tempo apresenta-se curto e condensado, necessário para eclodir o conflito da tensão dramática das mortes dos protagonistas, quando se enfatizam o futuro dos que continuam vivos e a recordação da fidelidade de Toni.

É possível reconhecer nitidamente como o espaço se organiza, dividindo a ilha: (a) nas matas montanhosas nomeadas berço das gaivotas, onde as personagens representantes do exército francês e os brancos fugitivos da revolta dos negros se escondiam, e, futuramente, nomeado de morada da paz eterna, ao se tornar local do túmulo dos defuntos Toni e Gustav; (b) e, nas plantações de Congo Hoango, com sua sede isolada à beira da estrada, casa em que quase todos os acontecimentos se produzem no romance.

Não há descrição detalhada de ambientes e paisagens, ou de rostos ou de corpos das personagens. O espaço diegético é composto de concretude. A Casa Grande, por exemplo, aparece a partir de pequenos cômodos, caracterizados pelas peças que os compõem: a mesa para o jantar (sala de jantar); o guarda-roupa e a cama (quarto); a corda pendurada na parede do 
quarto; o relógio de parede; a bacia de água quente; e as janelas, ora fechadas ora abertas, por onde se observa o horizonte.

A voz narrativa pouco comenta o interior dos ambientes. Essa imprecisão contrasta com a luxúria na atitude das personagens. O drama amoroso desenvolve-se no interior da casa, com as janelas fechadas, apenas abertas para a brisa do vento noturno a acariciar os corpos nus, sinal de liberdade, ou para Toni observar o horizonte e ver o perigo que vem a galope: Congo Hoango. O sol aparecendo timidamente lá fora contrasta com sombras interiores.

O olhar do protagonista para a cor da mulata ou o rosto de Toni associa-se à claridade produzida pela luz artificial. Há momentos de uma claridade atenuada por onde a luz penetra lentamente no ambiente, encaminhando a cena para o instante em que a porta se abre com violência e o viajante suíço apresenta-se entre a escuridão da noite e da sala, e a luz artificial da lua e da lanterna: assim, "os pólos de ordem binária [...] cruzam-se completamente de tal forma, que não seria possível diferenciá-los.[...] A poesia aparece completamente objetiva" (BEIL, 2006, p.03).

Essa imagem desorganiza a casa e o espaço natural como num ritual de morte que se avizinha, e cuja presença demanda um mal metafórico, que transforma a casa em espaço negativo, pois a solidão e a morte se sobrepõem a tudo. A realidade humana e trágica do quadro se apresenta: enquanto a jovem agoniza na cama com o tiro no peito, Gustav isola-se a olhar perdido pela janela o horizonte, entregando-se ao infindável devaneio. O dilaceramento e a interiorização intensificados projetam-se na ação suicida do protagonista e 
nas cores branca e vermelha, mistura dos pedaços de "crânio do coitado, destroçado [que] espalhava-se pelas paredes" (Kleist,1992, p.179).

Ao analisar a correlação simbólica do ambiente em $O$ Noivado em São Domingos, Beil situa o romance alemão quanto:

[...] a leitura de um teatro da percepção ou do reconhecimento. [...] essas verificações foram apresentadas como concretização narrativa do esquema colonialista preto-branco. É verdade que a mestiça mescla em diversos momentos essa estrutura dual, no geral as analises se contentam com o fato de que a entrada de uma pessoa de cor no mundo dos brancos seja aqui apresentada como ascensão e que Toni, desta forma, seja totalmente apanhada pelo dualismo da construção da raça (HERMANN apud BEIL, 2006, p.03)

Portanto, em O Noivado de São Domingos a ambigüidade impera, especialmente no que concerne à questão racial. Gustav não consegue confiar em Toni e acaba sendo vítima de suas próprias desconfianças.

Já o título Bug-Jargal, de Victor Hugo, informa sobre o herói que leva o nome do romance: de simples escravo a chefe dos grupos de Marrons. Tratase, portanto, de uma narrativa que, também, se ambienta no quadro da história da ex-colônia francesa de São Domingos, no momento do levante geral dos escravos em 1791. Esse acontecimento histórico que ecoa na trama produzida pelo escritor francês passa-se, tal qual O Noivado em São Domingos, na época das queimadas de plantações quilombolas, cujo episódio central também é a luta dos negros haitianos contra o regime escravocrata. 
O tempo em Bug-Jargal recobre os acontecimentos em torno de 22 de agosto de 1791, início das insurreições. Aparece inicialmente a informação do nascimento do senhor Aurverney, na França, e sua ida para São Domingos, para viver com o tio e, no futuro, casar-se com a prima Maria. A idade da personagem Maria, bem como a data do casamento coincidem com a marca histórica de 22 de agosto: "irmão, devo-te tanto, preciso aconselhar-te: vai até o cabo e casa antes de 22 de agosto" (HUGO, 1946, p.20) .

A narrativa, é ulterior à diegese, e a situação colonial é explícita, com conquistas políticas "contra franceses, ingleses e espanhóis, envolvendo muitos soldados franceses a favor da abolição" (ALMEIDA, 2009, p.95):

Quando os cultivadores negros vieram até eles, preocupados a respeito da própria liberdade e da dominação branca, ele pegou um vaso de vidro e o encheu com grãos de milho preto; depois, depositou neles uns grãos de milho branco.

-Vois sois o milho preto; os brancos que vos querem escravizar são o milho branco!

Então chacoalhou o vidro e mostrou a eles.

-Veja! Os brancos estão espalhados apenas ali e aqui! (HUGO, 1946, p.231)

A história é narrada pela memória de Leopoldo d' Auverney e de seu amigo Jack, na qual o presente cumpre o papel de centro coordenador, permitindo, coordenando e interrompendo as digressões efetuadas no pretérito. O presente vai se alternado com o pretérito, permitindo acompanhar a rememoração das personagens sobre as revoltas na llha. Esses acontecimentos subjetivos do pretérito são coerentes e sólidos, e o presente da 
narração se integra a ele, num contínuo, reduzindo a distância do pretérito pelo discurso direto. Todos os sentimentos encerram o passado e o presente vivido como oficiais do exército francês, na luta na ilha de São Domingos, e a amizade que ambos consolidaram com o líder Bug-jargal.

$\mathrm{Na}$ primeira parte, por exemplo, vale destacar os registros, localizados no encontro no jardim com o gigante Bug-jargal. A impossibilidade do amor de Bug-Jargal por Maria, acrescentada à consciência que a personagem tem desta impossibilidade, juntamente com as músicas chorosas, constituem o espaço da imersão em um passado distante, no qual, como rei na África, podia manifestar os seus sentimentos e ser correspondido.

Os narradores valem-se, também, de breves resumos para apresentar anos vividos na propriedade do tio e pai da noiva, dispersos na primeira parte da obra. Essas anisocronias reforçam aspectos das posições políticas entre os grupos e refletem as personagens binárias exército/revolucionários negros; senhor/escravos; e branco/negro, nos seus diversos desdobramentos.

A evocação de Auverney ao passado do tempo da colonização francesa e os acontecimentos relacionados à Independência haitiana, como movimentadores das ações, constituem-se a história propriamente dita da segunda e terceira partes da narrativa.

Em Bug-Jargal as reiteradas cenas dialogadas, por meio do discurso direto, produzem uma sequência temporal próxima ao tempo cronológico, enquanto os narradores indicam a maior individualização de seu passado com outras personagens. Mantêm-se na primeira pessoa, como narradores 
autodigéticos, relatam fatos presentes e passados num registro de participante e testemunha da diegese.

Elemento-chave da problemática da escravidão, a coerção e a tortura não faltam na narrativa, comparecendo ora na casa de propriedade do branco, ora na floresta com os negros, como Bissau. Essa sua dupla presença revela o desejo de poder tanto do exército quanto dos negros.

Omaya (2009, p.112) considera que essa construção narrativa reflete as questões políticas da época: Bissau quer ser monarca e incorpora atitudes violentas e o desejo de criar uma nação. Assim, todos os objetos da gruta - a cadeira-trono, o cetro, no alto do mato, no meio da floresta, em pleno ambiente de Marrons, caracterizam a vontade de realeza num espaço grotesco. Os objetos da casa grande, o luxo das cortinas e as flores do jardim colocam Maria como a rainha virgem, vitoriosa, uma estátua grega. Portanto, no romance de Victor Hugo a expressão do mundo colonial é dicotômica ao extremo, pois tanto tio de Auverney, dirigente branco, como os dirigentes negro ou mulato são representantes de líderes violentos e absolutistas e exploradores de escravos.

\subsubsection{O Modo De Contar Do NarRador}

A narração e a representação de $O$ noivado em São Domingos correspondem ao discurso indireto livre. O narrador se projeta sobre a instância narrativa, representa-se na terceira pessoa, conferindo caráter objetivo.

O leitor observa os acontecimentos se materializando à sua frente, através de um narrador que descreve as sequências de ação e reação 
envolvendo as personagens, olhando apenas de viés para o ambiente e os sentimentos das personagens. Há um aparente ambiente de segurança e tranquilidade que, futuramente, se quebra com a morte de Toni e o soldado suíço. A impressão que fica ao leitor é de que esses acontecimentos fazem parte de uma condição corriqueira.

Considerando o seu quadro histórico, vê-se que o narrador do romance põe em evidência a desordem social, na qual escravos manifestam-se contra seus senhores:

Em Port au Prince, na parte francesa da ilha de São Domingos, vivia, no começo do século, quando os negros matavam os brancos, na plantação do senhor Guillaume Villeneuve, um terrível e velho negro chamado Congo Hoango. Esse homem, originário da costa dourada da África, que na sua juventude parecia ter um espírito de fidelidade e justiça, foi descoberto pelo seu senhor, de quem, havia salvo a vida, numa travessia para Cuba, por infinitas benfeitorias. Não apenas porque o senhor Guillaume the tivesse dado imediatamente a liberdade, e, na sua volta a São Domingos, casa e trabalho; ele o transformou até, anos depois, indo de encontro aos costumes da ilha, em guardião de sua propriedade, e lhe deu, pois não queria casar novamente, uma velha mulata chamada Babekan, da sua plantação, da qual era um parente afastado, através de sua falecida esposa. Pois bem, quando o negro alcançou seu sexagésimo aniversario, foi aposentado com um ótimo salário e coroou as sua benfeitorias com um legado deixado em testamento. Mas todas essas provas de gratidão do senhor Villeneuve não puderam o proteger da ira aquela feroz pessoa. (1992, p. 1454). 
O narrador parece assumir, aqui, uma posição francamente a favor do senhor Villeneuve, ou seja, "uma posição em conformidade com seu tempo" (Beil, 2006, p.05). No entanto, a concisão narrativa apresenta-se até o final da diegese, com detalhamento na apresentação dos acontecimentos, através de um narrador comedido e indiferente aos acontecimentos. Esse narrador difícil de ser confiscado, escorregadiço, fendido é o mais contraditório possível, porém, essa contradição se processa em unidade na narrativa.

O narrador de O Noivado em São Domingos serve-se de um realismo marcado e singular, apresentando os acontecimentos com objetividade. Assim, limita-se à função exclusiva de narrar os fatos, mostrar a história do Congo Hoango com uma grande variedade de informações a respeito dele, descreve como agem as personagens e como reagem aos diferentes ou desejados eventos, guardando distância dos seus mundos interiores. Parece sempre estar colocado a observar os acontecimentos, sem expor juízos de valor sobre estes.

Segundo Beil, durante ass décadas de 1970 e 1980, Kleist é visto pela crítica como um "narrador irônico hábil que citava o racismo de seus contemporâneos, expunha-os consciente, mas rompia com ele artisticamente (2006, p.04). Carpeaux (1960), em Livros na mesa, observa:

Sabendo que a existência humana não tem fundo nos nossos pés, Kleist não admitia ilusões. É de um realismo implacável, contando as coisas mais monstruosas ou pelo menos inesperadas como se fossem lógicas e naturais. As personagens do dramaturgo Kleist são caracteres: nesta vida 
"sem fundo" guardam coerência ferrenha que nenhum acontecimento é capaz de quebrar. (p. 47-48)

Para Carpeaux, o acontecimento é a marca da produção literária de Kleist em que determinadas situações rompem do cotidiano e produzem um rumo inesperado à vida de suas personagens.

Rodrigo Castro em Michael Kohlhaas - a vitória da derrota (2006) avalia que no mundo apresentado pela prosa de Kleist, os conceitos passam ao seu contrário sem parar, esvanecendo-se a cada tentativa de fixá-los. 0 narrador serve-se de uma estrutura que trata de tirar o controle sobre os acontecimentos, em nome de garantir-Ihes a autonomia, pois ao final desse esforço de interpretação estará traçado um perfil do sujeito moderno e de seu caráter alienado (p. 06).

A tragédia surge da falha de Gustav em não confiar na amada, pois as aparências escondem a verdade. Portanto, o jogo da aparência e da essência é o tratamento permanente dos problemas de preconceito racial e escravidão em Kleist.

Na objetividade do narrador heterodiegético, a visão subjetiva das personagens se desvenda pelos seus comportamentos. Personagens como Toni, Gustav, Babekan e Congo Hoango enrubescem e empalidecem várias vezes, balbuciam ou gaguejam, silenciam ou respondem rudemente, desmaiam ou ficam em transe, tremem e estremecem, despem ou trocam carícias. São construídas com qualidades contraditórias, não lineares, porque há na dinâmica da ação narrativa a reação. O objetivo parece mudar a cada instante, 
e as personagens procuram adaptar-se, resistindo e se submetendo até retornarem em conflito com o mundo, pois "o narrador não escapa do fato de que a ordem das coisas por ele próprio idolatrada não está mais intacta" (BAY apud BEIL, 2006, p.04).

O narrador, todavia, não adentra os pensamentos ou sentimentos das personagens, escolhendo descrever de maneira direta o estado de espírito delas. Nesse jogo de recusa do interior, tem-se a impressão de representação histórica, em uma linguagem rebuscada, repleta de orações subordinadas, " de estilo complexo, enovelado, criando tensões e dando ao ritmo da frase estilhaçada um caráter ofegante e furioso" (NEUMAN, 2003, p.190, apud CASTRO, 2006)

Há momentos singulares na narrativa, como, por exemplo, a apresentação das ações das personagens, sem digressões. Quando ocorre o desenrolar da história com a chegada de Congo Hoango, tem-se um efeito determinante sobre as vidas das personagens, uma mudança brutal, reorganizada pelo passado e condicionando o futuro delas.

Agora cabia salvá-lo; mas o crânio estava destroçado e como ele havia apontado a pistola para a boca, espalhara-se pelas paredes. O senhor Stromli foi o primeiro a se recuperar. Pois o dia já clareava e brilhava através das janelas e corria a notícia de que os negros começavam a se mostrar no pátio.(KLEIST,1992, p.179) 
O cérebro destroçado e espalhado pelas paredes parece irrelevante diante dos próximos acontecimentos: o dia claro e brilhante e os negros no pátio. Esse narrador historiador e jornalista dos eventos modernos, das revoltas escravagistas e sobretudo humanas, constrói uma narrativa em que os sentimentos pontuam toda a trama, sempre comunicados pelas ações das personagens. O movimento de toda a diegese está nos acontecimentos e na maneira como o narrador os relata. E sobre eles o leitor encaminha-se sem nenhum intervalo ou desvios explicativos, para polos binários, em que o bommau, branco-preto, leal-desleal entram em conflito e nenhuma posição de verdade parece ser possível, pois a aparência contraria a essência das personagens.

A personagem Congo Hoango é descrita em conformidade com o tempo, como infrator e vítima rebelde, ingrato e cruel, movido pela "vingança que se propagava nessas plantações por causa dos passos imprudentes da convenção nacional" (1992, p.145). Foi um dos primeiros a disparar a arma contra o seu senhor com "desumana sede de vingança" e obrigou Babekan e sua filha mestiça a ajudá-lo a atrair brancos fugitivos para casa e matá-los.

A personagem Toni é ambígua, transforma-se de acordo com o que vivencia no mundo à sua volta: de auxiliadora de Congo Hoango na matança dos brancos à salvadora cristã de Gustav. A cruz de Mariane dada por Gustav após a noite de amor e a cena da personagem se ajoelhando para orar é extremamente ambivalente, pois não esclarece para o leitor se ela dormira com ele e fingiu aceitar os valores cristãos para adquirir a confiança dele e matá-lo, posteriormente, ou se realmente, se arrependeu de seu intento e passou a querer de fato protegê-lo. 
A personagem branca Gustav também é ambígua: apresenta-se na casa e, inocentemente, aceita ficar, mesmo recebendo informações que ali era a moradia de um negro feroz e vingativo. Acredita estar protegido pela aparência jovem e doce de Toni, mas era evidente seu conhecimento sobre o risco que ali corria.

No jantar, Gustav conta duas histórias sobre negros e brancos: uma de uma negra traiçoeira que tinha febre amarela e prende seu patrão na cama para infectá-lo; outra de uma branca, quase santa, que morreu pelo amado. Em ambas as histórias, pode-se colher o discurso de um narrador colado a personagem, com a perspectiva branca colonialista.

A mestiçagem de Toni não se apresenta de modo positivo ou negativo, mas sim pela imprecisão: tem a pele amarelada, iluminada pela luz do Sol ou da lanterna, nem branca, nem negra, a pele amarelada é sinal de ambivalência ou de desconhecimento em relação à personagem.

O encadeamento dos acontecimentos segue uma amarração rigorosa em que se estabelecem relações de causas e consequências. O leitor é informado dessas seqüências ordenadas: Toni foi impedida de salvar o soldado; viu-se obrigada a abandonar os objetivos iniciais da vingança de seu padrasto e de sua mãe; descobriu-se apaixonada pelo soldado; entregou-se a ele; encaminhou uma carta às escondidas pelo próprio filho do padrasto a família do soldado, esclarecendo o perigo que ele corria em sua casa; ouviu que a culpa era dos franceses e brancos; descobriu a inocência do soldado na história dramática relatada por ele; atuou no sentido de salvá-lo, e o soldado acreditou que ela o traiu e a matou, suicidando-se em seguida. 
Os dois corpos foram postos numa tábua, já que não se queria que estivessem à cruel violência dos negros e depois de recarregarem as espingardas, o triste séquito partiu rumo ao berço das gaivotas. O senhor Stromli, com o garoto Seppy nos braços, ia na frente. Seguiam-no os dois criados mais fortes, os quais carregavam nos ombros os corpos; o ferido vinha atrás, mancando, ajudado por um bastão; e Adelbert e Gottfried iam ao lado do lento cortejo fúnebre, espingarda em riste. Os negros, como viram tão parco grupo, avançaram, saíram de suas casas com lanças e forcados, parecendo que queriam atacar; mas Hoango, o qual fora desarmado, apareceu na escada na casa e acenou para os negros, a fim de que se acalmassem. "Em Santa Lúcia!", gritou ele para o senhor Stromli [..] (1992, p.179)

A ambiguidade aparece mais uma vez, agora na cena final, quando o líder negro evoca Santa Lúcia e protege o cortejo de morte do casal de amantes. A ambigüidade se dá em todos os níveis.

Beil (2007, p.03) identifica diversos momentos ambíguos no texto de Kleist. A cena da lavagem dos pés é apresentada pelo narrador como um ritual ocidental cristão, o qual pode ser lido como: um serviço para angariar confiança do branco; ou referência ao contexto bíblico, relembrando o ato de uma pecadora arrepentida. Ou seja, "mistura escandalosa de dois polos preto e branco do discurso colonial" (p.03). Também a cena das amarras são apresentadas pelo narrador no momento do trágico mal entendido, erro de interpretação, de Gustav. Beil reconhece que a corda faz o nó. Ao emaranhar a opção negra com a branca, uma a outra, de forma a se criar um discurso erótico nas tessituras narrativas, Kleist vai muito além de validar o discurso 
colonialista (BEIL, 2007, p.04). A corda pode salvar e pode estrangular. Os objetos com duplas possibilidades enunciativas reforçam a retórica de percepção do outro, de afeto e de hibridização como força subversiva da obra de Kleist.

Na obra Bug-Jargal, de Victor Hugo, os narradores autodiegéticos, de focalização interna, oferecem-se à voz da narrativa como testemunhas da revolta em São Domingos. O narrador do romance põe em evidência a manifestação de desordem social, onde escravos manifestam-se contra seus senhores, e se movimenta em vários ângulos de focalização: ora do escravo, ora do branco, ora do mestiço.

O narrador, no capítulo XVI, faz a sátira de uma cena da Assembléia Provincial, onde se reúnem brancos, mulatos negrófilos e senhores mais radicais: de um lado o senhor $\mathrm{C}$...propõe o massacre de mais de cinquenta negros de uma maneira insólita, pois nem participavam do movimento da revolta e, quando é descoberto como um negrófilo, a situação se reverte.

Tais posicionamentos do narrador aponta o modo como ele escolhe denunciar a escravidão e defender a abolição: descreve o sofrimento dos negros nas plantações, nos castigos, nas prisões, no trabalho animalesco, sob o autoritarismo do tio de Auverney. Para Omaya (2009, p.123) a personagem Auverney é um alterego de Victor Hugo, perceptível na reflexão que faz ao desmascarar o autoritarismo imposto pelo branco, pelas relações de ódio estabelecidas entre brancos, negros e mulatos.

A personagem Bug-Jargal constrói-se como herói ao modelo francês, amigo dos negros e escravos, um homem forte, de bom caráter, porém rebelde 
ao seu senhor. O narrador descreve a cena em que Bug-jargal segura o chicote do tio de Auvernery para que ele não bata no escravo negro que estava dormindo. A retirada da autoridade do senhor branco produz a trágica sequência de acontecimentos e a morte de Bug-Jargal.

Há uma tonalidade nostálgica colocada pelo narrador no relato de Bug-Jargal sobre sua origem africana, no reino longínquo de Kakongo, como rei, capturado e educado por um espanhol. A paixão por Maria, branca ao molde europeu, propõe a interligação desse "mestiço de formação", conforme categoriza Garmes (2003, p.189), pois o que vale é a cultura da metrópole colonial. Portanto, Bug-Jargal se revela como um negro que sofreu um processo de branqueamento e despersonificação cultural, mas, ainda assim, conhece o valor de sua origem.

Maria é construída pelo narrador como uma moça celeste e perfeita, virtuosa, contrastando com as mulheres negras, sempre dispostas ao requebro e ao canto, feito bruxas. A figuração de mulher branca, disposta ao casamento para assegurar a herança familiar, aponta-a como pertencente à classe dominante, sem predisposição para conhecer a cultura crioula, mestiça local.

Em Bug-Jargal, de Victor Hugo, o narrador apresenta as personagens Bissau - o generalíssimo-, e o governador francês, moldadas a um comportamento violento e ditador. O governador com outros brancos executa negros que não estavam nos movimentos revolucionários, expondo suas cabeças pelas ruas, como manifestação de seu domínio como representante do exército francês. Bissau julga, condena e executa seus prisioneiros num misto de ferocidade e autoridade máxima. Ele, juntamente 
com Habibrah, tem poderes sobre a vida dos prisioneiros brancos, mestiços e negros. O narrador faz a personagem Bissau demonstrar a intensidade do racismo e do preconceito de classe vigentes naquela altura.

Claudia Almeida (2009, p.98) considera que, em relação à questão da raça, a mestiçagem é a camada mais desprestigiada, tomando por referência a personagem Ogé. Quando o narrador descreve o acampamento dos escravos rebelados, "sobre a cabeça do chefe, uma figura chamou-me a atenção: o retrato do mulato Ogé, enforcado no Cabo, um ano antes pelo crime de rebelião". (HUGO, 1946, p.75).

Almeida acrescenta que a personagem Ogé fez parte da elite mulata de São Domingos na história real, e lutou pelo direito da representação política. Apesar da posição intermediária entre branco e negro, ninguém lutou pela aceitação do mestiço na sociedade colonial.

A personagem mestiça Habribah é apresentada pelo narrador como um monstro. Ele representa o sentido ambíguo que o mestiço tinha na sociedade colonial: ora um libertário, como Ogé; ora um crápula, como Habibrah.

Essa personagem é construída como um "anão disforme que acompanha o tio de Leopoldo e tem a semelhança dos antigos príncipes feudais" (HUGO, 1946) e com aspecto animalescos,

repulsivo, era gordo, barigudo e movia, com singular rapidez duas pernas magras e débeis que quando se sentava, ficavam sobre ele dobradas como as patas de uma aranha. 
Sua cabeça descomunal, pesadamente fundida entre os ombros eriçadas de uma lã vermelha e cuspa, tinha como apêndice umas orelhas enormes, das quais seus camaradas caçoavam. (p.15, grifos nossos)

Embora Habribah sucumba ao poder dominante, referendando-o, ele introduz um sentido diferente de alteridade: originário de sua relação com o outro, e consciente de sua mestiçagem. Ele ainda introduz o elemento africano e o racismo, inerente à colonização, ao apresentar a cerimônia religiosa no castelo imaginário, uma mistura de vodu e de cristianismo que legitima o sincretismo religioso.

Omaya (2009, p.119) afirma que o poder de Habribah na cerimônia imprime aos negros e em Auvernery a "sobreposição da missa sagrada sobre o ambiente e os fieis crioulos, bem como o texto relatado pelo pai capelão produz a francofobia: '-Zoté cone bom Giu; Ce li mo fé soté voer. Blan touyé li, touyé blan yo toute'Nous connaissez Le bom Dieu;C'est lui que jê vous faiz voir. Lês brancs l'ont tué; tuez tous lês brancs!'”(HUGO, 1953, p.146).

Para Omaya, o discurso do narrador sobre a execução e encaminhamento da missa vodu emigra para desqualificação e depreciação, pois o Habibrah exerce diversas funções: médico, padre, feiticeiro e vidente junto aos guardas (2009, p.127). Todavia, acredita-se que o fato de a personagem apresentar aspectos ambíguos e contraditórios do mundo colonial, traduz a necessidade de afirmação da cultura mestiça, pois a religião do branco está nas mãos do feiticeiro, o detentor do poder vodu. 
Em termos de estratégia discursiva, seu movimento seria o da guerra de oposição, em que se vale da ambivalência do discurso colonialista para macaqueá-lo e, ao mesmo tempo, produzir sua transparência negativa, espelhando sua instabilidade e ambiguidade.

\subsubsection{Os Romances Em Diálogo Com O Escravo}

Os romances O Noivado em São Domingos, Bug-Jargal e O Escravo constituem-se em obras que tratam da questão racial e da escravidão dentro de um mesmo sistema literário europeu

Essas duas temáticas estão entrelaçadas com a história da Nação haitiana nos dois primeiros romances e com a história de Cabo Verde, em $O$ Escravo. As narrativas apresentam esses problemas temáticos como denúncia do jogo de poder e da corrupção política do momento.

Com se observou, há aspectos nas narrativas de Kleist e de Hugo que caracterizam a constituição do movimento revolucionário dos negros na Ilha de São Domingos. Porém, enquanto nos primeiros romances citados, os acontecimentos ficcionais giram em torno do contexto histórico da época, no romance caboverdiano, esse movimento é apenas tangencial, já que nem a consciência da personagem João, nem a revolta ali apresentada caminham no sentido de uma tomada de posição histórica contra a política colonialista. 
Mas se a questão colonial não é abordada, as questões racial e escravagista são. O abolicionismo está na base dos três romances e ainda que Hugo e Kleist queiram relativizar o colonialismo, o discurso colonial é o que fundamenta as representações culturais ali presentes, que serviu para proceder a hierarquização das culturas.

O argumento colonial legitima a necessidade da assistência cultural europeia e defende o acolhimento caloroso e humanitário do negro e o combate à escravatura. Assim, o discurso nas narrativas assegura e legitima a colonização, por meio de uma cooperação educativa, religiosa e jurídica, o que justifica a hegemonia da cultura europeia sobre as outras.

As falas das personagens em O Noivado em São Domingos são apresentadas sem aspas e sem marcação do discurso direto, desaparecendo, assim, a fronteira entre o discurso do narrador e o da personagem. Diferenciase, portanto, da estrutura narrativa dos outros romances, demarcados pelo discurso das personagens. $\mathrm{O}$ afastamento dos narradores em Bug-Jargal e $O$ Escravo produz legitimidade ao enunciado e maior densidade interior às personagens do que o narrrador do romance alemão, do qual o leitor sempre desconfia.

Nos romances de Kleist e Hugo, os discursos dos narradores enfatizam a escravidão de modo mais persistente, voltado à emancipação política da ilha de São Domingos, o que não ocorre em O Escravo, no qual a escravidão mais preponderante é a amorosa, coexistindo também "a escravatura de condição, a de ignorância e ambição" (VEIGA, In: Almeida, 1989, p.14) 
O tema amoroso é tratado nos romances de modo semelhante: uma grande tragédia. $\mathrm{Na}$ narrativa caboverdiana, o sentimento subjetivo torna-se maior do que o sofrimento da condição social da escravatura; na literatura alemã, o trágico está no drama moderno do homem como joguete do destino; na literatura francesa, o tema é ofuscado para dar lugar à relação de amizade entre os homens, independente de sua condição de raça ou de escravatura.

Assim, a morte é a metáfora possível para os escravos Bug-Jargal e João, diante da conquista amorosa das protagonistas. A união, só concretizada pós-morte, afirma a única condição possível de união do escravo negro com a senhora branca ou com a mestiça da elite social. Dessa forma, "a mola propulsora de toda sentimentalidade romântica fica ofuscada por uma relação de motivação social, de hábitos e costumes" (GARMES, 2003, p.200). Compreende-se que nas histórias de amor, o impedimento está na questão racial e pode se concretizar à medida que a formação cultural dos pares se aproxima: João/Maria e Bug-Jargal/Maria caracterizados pela formação europeia, acontecendo o mesmo com Toni e Gustav, o que constrói a verossimilhança amorosa dessas narrativas. Porém, em O Escravo e em BugJargal há triângulos amorosos. Enquanto em Bug-Jargal ambos pretendentes são de caráter ilibado, em $O$ Escravo, Lopes é o branco fora da ordem social estabelecida, pois é a representação do colonizador que só quer explorar a Colônia.

A figura idealizada do escravo apaixonado pela sua senhora aparece nos romances de José Evaristo e de Victor Hugo, reforçando a diferença entre as camadas sociais. Porém, o amor reprimido de Bug é minimizado em função do conflito relacionado à amizade entre os negros e brancos. 
Já no romance de Kleist, o tema amoroso entre os protagonistas ocorre na mesma camada social, pois ambos representam o status da elite da llha de São Domingos. A diferença reside na raça mestiça de Toni e no medo que se estabelece no lugar em função das revoluções dos escravos e mestiços. Um erro cultural determina a consequência do final trágico do seu destino - o suicídio.

Victor Hugo e José Evaristo de Almeida criaram em suas obras personagens negras e mulatas, que se destacaram pela presença de elementos de proveniência africana, como o batuque e a manifestação cultural das danças, cantorias e rezas. Esse procedimento de valorização da cultura local e/ou da cultura africana, não aparece na obra alemã. As protagonistas mestiças de O Escravo e de O Noivado em São Domingos revelam conhecer mais a cultura cristã e a educação europeia, mostrando-se portando despersonificadas, porém agregadas à construção de uma identidade cultural que se desejava em ambas as Colônias.

Bug-Jargal e João aproximam-se pela construção discursiva do modelo heróico, cristalizado nos compromissos éticos, sobretudo, não violentos. Encarnam o ideal de uma colonização moderada, do tipo patriarcal, preocupada em poupar as forças humanas para a prosperidade da Colônia, e para quem os escravos saberiam mostrar-se reconhecidos pela "bondade" e "humanidade" dos senhores.

Há aproximação entre a personagem rebelde mestiça Habibrah e a negra feiticeira Júlia, pois ambas representam o ressentimento contra os 
brancos e a resistência à aderência da cultura europeia e aos princípios culturais das metrópoles coloniais.

A questão da mestiçagem em Bug-Jargal ocorre também pelo âmbito linguístico como em O Escravo. No primeiro, as línguas inglesa, espanhola e crioula recebem um tratamento especial, com devidas notas de tradução do autor. No segundo, a consciência linguística do escritor está na apresentação do crioulo caboverdiano, do contador de história oral, pelo narrador, com as notas explicativas demarcando, assim, a distinção cultural entre o colonizador e o colonizado.

Victor Hugo experimenta a condição de revolta, de oposição aos motivos de uma ditadura política e defende a ação social e humanitária. Kleist permite ao leitor experimentar a relatividade das escolhas e posições, e principalmente do drama humano. José Evaristo de Almeida traz a perspectiva romântica e humanista de assimilação de uma mestiçagem pautada nos valores europeus.

Não por acaso que se estabelecem inúmeras relações e comparações entre essas três obras. Gestadas no macrossistema literário europeu (cf. EVEN-ZOHAR, 1990, p.50), tais romances abordaram uma temática recorrente entre os romances europeus oitocentistas.

Ao situar o romance $O$ Escravo no sistema literário português, entendendo "sistema literário" a partir da perspectiva de Antonio Candido, isto é, como um sistema que intencionalmente se constrói por referência a uma identidade nacional, constata-se sua pouca expressividade, haja vista a lateralidade da temática da escravidão e da raça na literatura portuguesa 
oitocentista. Todavia, foi possível constatar seu estreito diálogo com outras obras da literatura europeia que the era coeva, revelando, assim, o lugar no qual o romance $O$ Escravo tem, de fato, sua maior expressão.

O Escravo, juntamente com os romances aqui estudados, cumpriram o importante papel de dar estatuto literário e legitimar o debate em torno do problema de escravidão e do preconceito racial 


\section{REFERÊNCIAS}




\section{OBRAS REFERENCIADAS}

ABDALA JUNIOR, B. "Antonio Candido: Formação da Literatura Brasileira”. In: MOTA, L. D. (Org.) Introdução ao Brasil: um Banquete no trópico. 3 ed. São Paulo: SENAC, 2001, p. 358-79.

. "Antonio Candido: Formação da Literatura Brasileira". In: MOTA, L. D.(org) Introdução ao Brasil: um Banquete no tropico. 3 ed. São Paulo: SENAC, 2001.

(Org). Margens da Cultura: Mestiçagem, Hibridismo e outras misturas. São Paulo: Boitempo, 2004.

Notas Históricas: Solidariedade e relações comunitárias na literaturas dos países africanos de língua portuguesa. In: Revista Niterói, № 24, p. 31-44, 1.sem. 2008.

ABREU, M. (Org.) Literatura e História - presença, leitura e escrita de romances. In:__. Trajetórias do romance: circulação, leitura e escrita nos séculos XVIII e XIX. São Paulo: Mercado das Letras, 2003. p. 11-19.

AGUIAR E SILVA, V. M. de. O Teatro de Actualidade no Romantismo Português. Coimbra: Coimbra Ed., 1965.

AGUIAR E SILVA, V. M. de. Teoria da Literatura . 8. ed. Coimbra: Almedina, 1973.

ALBUQUERQUE, L. de. "O descobrimento das ilhas de Cabo Verde". In: SANTOS, M.E.M.; AlBuqueRQUE, L. de. (Coord). Historia Geral de Cabo Verde. Lisboa: Instituto de investigação Cientifica Tropical de Portugal / Praia: Instituto de Investigação em Cabo Verde, 2001. v1, p.23-39. 
ALMEIDA, J. E. de. O Escravo. 2. ed. Cabo Verde: ALAC, Instituto Caboverdiano do Livro, 1989.

ALMEIDA, C. B. V. de. O Escravo: entre a Identidade caboverdiana e a literatura européia. Dissertação (Mestrado em Estudos Comparados de Língua Portuguesa)Faculdade de Letras de São Paulo-USP, 2009.

ARANTES, P. E.; ARANTES, O. B. F. Sentido da Formação: três estudos sobre Antonio Candido, Gilda de Mello e Lúcio Costa. Rio de Janeiro: Paz e Terra, 1997. p. 7-67.

ARAÚJO, J. L. M. de. "A Formação, os deslocamentos: Modos de escrever a história literária brasileira". In: Revista Brasileira de Literatura Comparada, n. 9, Rio de Janeiro: Abralic, 2006. p.13-47.

BARBOSA, J. A. "Teoria e prática de Antonio Candido". In: Revista Brasileira de Literatura Comparada, n. 19, Rio de Janeiro: Abralic, 2000, p.29-41.

BASTOS, J. J. R. de. A Virgem da Polônia. Lisboa: Imprensa Nacional, 1847.

BEIL, U.J. A Subversão da História pela Literatura: O Noivado em Sao Domingos. In: Revista Pandemonium Gemanicum. 11/2007, p. 1-14.

BHABHA, Homi. O Local da Cultura. 3. ed. Belo Horizonte: UFMG, 2005.

BOTO, Carlota. Iluminismo e Educação em Portugal: o legado do século XVIII e XIX. RJ: Vozes, 1997.

BRAGA, T. História da Literatura Portuguesa.O Romantismo. Lisboa: Europa-América, s/d.

BUESCU, H C. (coord.) Dicionário do Romantismo Literário Português, Lisboa: Editorial Caminho,1997. 
CABRAL, A. Análises de Alguns Tipos de Resistência. Lisboa: Seara Nova, 1975.

CALBUCCI, E. A construção do ator da enunciação em romances com narradorpersonagem: a experiência machadiana em 'Mémorias póstumas de Brás Cubas'. Tese (Tese em Semiótica e Lingüística Geral)- Faculdade de Letras de São PauloUSP, 2007.

CANDIDO, Antonio. Formação da Literatura Brasileira: Momentos decisivos.. São Paulo: Martins, 1961. 2 v.

CANDIDO, Antonio. Literatura e Sociedade: estudos da teoria e história literária. São Paulo: T. A. Queiroz, 2000. . "Direito à Literatura". In: Vários Escritos. 3.ed. Corrigida e aumentada. São Paulo: Duas Cidades, 1995. p. 215-31.

CALLADO, A.. "Formação da Literatura Brasileira: um monólogo interior". In: D'INCAO, M. A.; SCARABOTOLO, E. F. (org.) Dentro do texto, dentro da vida; ensaios sobre Antonio Candido. São Paulo: Cia das Letras, 1992. p.142-52.

CANIATO, B. J. L.. Hora di Bai: romance de Cabo Verde. Dissertação (Mestrado em Estudos Comparados de Língua Portuguesa)- Faculdade de Letras de São Paulo-USP, 1980.

. Maria Judite de Carvalho: a solidão de mulher. Tese (Doutorado em Estudos Comparados de Língua Portuguesa)- Faculdade de Letras de São Paulo-USP, 1988.

CARDOSO, F. H. Capitalismo e escravidão no Brasil meridional -o negro na sociedade escravocrata do Rio Grande do Sul. 4. ed. Sao Paulo: Paz e Terra, 1997. 
CARneIRO, M. L. T. Preconceito Racial: Portugal e Brasil-Colônia. 2 ed. São Paulo: Brasiliense, 1988.

CARPEAX, O. M. Livros na mesa. Rio de Janeiro: Topbook, 1960.

CARREIRA, A.. Cabo Verde - Formação e Extinção de uma Sociedade Escravocrata, 1480/1878. Lisboa: Centro de Estudos da Guiné Portuguesa, 1972

Notas sobre o Trafico Portugués de Escravos. Lisboa: Universidade de Nova Lisboa, 1983.

CARRIJO, F. de S. A busca da adequação enre formas literárias e momento Histórico: um estudo comparativo entre O Guarani, de José de Alencar e O Escravo, de José Evaristo de Almeida. Dissertação (Mestrado em Estudos Comparados de Língua Portuguesa)- Faculdade de Letras de São Paulo-USP, 2008.

CASTRO, R. P.. Michael Kohlhaas - a vitória da derrota: uma interpretação da novela Michael Kohlhaas de Heinrich Von Kleist. Dissertação (Mestrado em Literatura Alemã)Faculdade de Letras de São Paulo-USP, 2006.

CAUNA, J. de: Les sources historiques de Bug-Jargal: Hugo et la révolution haitienne. Centre d'Etudes Littéraires et Linguistiques Francophones et Africaines -Articles en ligne. France: Conjonction, ํㅜ16, 1985. Disponível em: http://www.msha.fr/celfa/article/DeCauna01.pdf Acesso: 20/08/2010.

CHAVES, R; M., T. Literaturas em Movimento: Hibridismo Cultural e exercício Crítico. São Paulo: Arte e Ciência, 2004.

CHIAPPINI, L. "Formación de la literatura brasileña o la historia de un deseo". In: Revista Casa de las Américas, n. 179, p.113-22, Havana: Editorial Pueblo y Educación, Março-abril de 1990. 
CHIAPPINI, L. "Os Equívocos da crítica à Formação". In: D’Incao, Maria Angela e Scarabotolo, Eloísa Faria (org.) Dentro do texto, dentro da vida; ensaios sobre Antonio Candido. São Paulo: Cia das Letras, 1992. p.170-80.

CITELLI, E. O Romantismo. São Paulo: Ática, 1990.

DANTAS, V. Bibliografia de Antonio Candido. São Paulo: Duas Cidades; Ed. 34, 2002.

DIAS, F. C.. Esboço da História da Literatura Indo-Portuguesa. Bastorá-Goa, Tipografia Rangel, 1963.

EVEN-ZOHAR, I. "Polysystem Studies." In: Poetics Today. Tel-Avi: The Porter Institute for Poetics and Semiotic, v.11, n 1, 1990.

Poetics Today, v. II, n.1, 1990.

. "El Sistema Literário". In: Poetics Today, v. II, n.1, p.27 -44,1990. Tradución de Ricardo Bermudez Otelo. Disponível em:

http://www.tau.ac.il/ itamarez/work/papers/trabajos sislit.s.htm Acesso em: 1/07/2010.

FANON, F. Pele Negra, Máscaras Brancas. Trad. Alexandre Pomar. Porto: Afrontamentos, 1979.

- Pele Negra, Máscaras Brancas. Trad. Alexandre Pomar. Porto: Afrontamentos, 1979.

. Os Condenados da Terra. Trad. José Laurêncio de Melo. Rio de Janeiro: Civilização Brasileira, 1968.

FERREIRA, A. Perspectiva do Romantismo Português. 2.ed. Lisboa: Editores Moraes, 1971.

FERRO, MARC. História das Colonizações: das conquistas às indepencias (SECULO XIII 
a XIX) Sao Paulo: Companhia das letras, 1994.

FOLHA DE S. PAULO. Entrevista a Antonio Candido sobre A Formação Da Literatura Brasileira.Cad. Ilustrada, São Paulo, 9/11/2006.

FRANÇA, J.-A. O Romantimo em Portugal. Lisboa: Livros Horizontes, 1993.

FERRAZ, M. de L. A Ironia Romântica: Estudo de um processo comunicativo. Lisboa: Imprensa Nacional, 1987.

GARMES, H. A Convenção Formadora: uma contribuição para a história do periodismo literário nas colônias portuguesas. Tese (Doutorado em Estudos Comparados de Língua Portuguesa)- Faculdade de Letras de São Paulo-USP, 1999.

GARMES, H.(org.) Oriente, Engenho e Arte: Imprensa e Literatura de Língua Portuguesa em Goa, Macau e Timor Leste. São Paulo: Alameda, 2004.

GARMES, H. (org). Imprensa e Literatura de Lingua Portuguesa em Goa, Macau e Timor Leste. São Paulo: Via Atlântica, 2004.

GARRETT, Almeida. Obras Completas. Lisboa: Emprensa da História de Portugal, 1966.

GENETTE, G. Discurso da narrativa. 3 ed. Lisboa: Vega, 1995.

GOMES, A. C. A Estética Romântica. São Paulo: Atlas, 1944.

GOMES, S. C. Cabo Verde: Literatura em Chão de Cultura. Cotia-Praia: Ateliê Editorial: Instituto da Biblioteca Nacional do Livro, 2008. . "Olhares Transversais Da Escrita Literária Sobre A Cultura Identitária Do Arquipélago: Do Dilema Do Primeiro Romance Cabo-Verdiano à Produção Contemporânea". In: CONGRESSO INTERNACIONAL DA ABRALIC: TESSITURAS, 
INTEGRAÇÕES E CONVERGÊNCIAS, XI. 2008. São Paulo, USP, p. 1-7. Disponível em: http: //www.abralic.org/anais/cong2008/ AnaisOnline/ simposios/ pdf/001/SIMONE_GOMES.pdf Acesso em: 29/09/2010.

HERCULANO, A. Herculano: Seleção de textos, notas, estudos biográficos, históricos e críticos e exercícios. São Paulo: Abril Educação, 1986.

HERNANDEZ, L. L. Os filhos da Terra do Sol: a formação do estado-nação em Cabo Verde. São Paulo: Selo Negro, 2002.

HUGO, Victor. Bug-jargal. In: Oeuvres Completes: Roman I. Paris: Laffont, 1846. . Prefácio de Cromwell. São paulo: Ateliê, 1988.

KAYSER, W. Análise e Interpretação da Obra Literária. Coimbra: Arménio Amado, 1976.

KLEIST, Heinrich Von. "O Noivado em São Domingos". In: A Marquesa de D' O e Outras Histórias. Rio de Janeiro: Imago, 1992. Trad. Claúdia Cavalcanti.

LINS, Osman. Espaço e romance. São Paulo: Ática, 1987 .Lima Barreto e espaço romanesco. São Paulo: Ática, 1976

LIMA, L. C. "Concepção de História Literária na Formação". In: D’INCAO, M. A.; SCARABOTOLO, E. F. (org.) Dentro do texto, dentro da vida; ensaios sobre Antonio Candido. São Paulo: Cia das Letras, 1992. p.153-69.

LOPES, A. F.M. Uma leitura do romance O Escravo, de José Evaristo de Almeida. Dissertação. Faculdade de letras do Porto, 2010.

LOURENÇO, E. "Da Literatura como Interpretação de Portugal". In: O Labirinto da saudade. 3를 ed. Lisboa: Dom Quixote, 1988, p.79-118 
LUCAS, F. Fontes Literarias Portuguesa. São paulo: melhoramentos, 1991.

MACEDO, T. "A Presença da literatura brasileira na formação dos sistemas literários dos países africanos de lingua portuguesa". In: Revista Via Atlântica, no 13, junho, 2008.

MACHADO, A. M., MONTEIRO, O. et al. (org). Historia da Literatura Portuguesa -O Romantismo. Lisboa: Alfa, 2003.

MARGARIDO, A. Estudos sobre literaturas Africanas de língua Portuguesa. Lisboa: A regra do Jogo, 1980.

MARIANO, G. Cultura Caboverdiana -ensaios. Coleção: Palavra Africana. Lisboa: Vega, 1991.

MATTA, R. da. Violência Brasileira. São Paulo: Companhia das Letras, 1982.

MORETTI, F. Atlas do Romance Europeu 1800-1900. Trad. Sandra Guardini Vasconcelos. São Paulo: Boitempo, 2003.

MOTA, C. G. "Antonio Candido e o combate às formas de pensamento reacionário" "Da literatura e da consciência nacional", "Análise de uma proposta para uma história da cultura no Brasil" e "Contra o Nacionalismo Deformante". In:__. Ideologia da Cultura Brasileira. 4 ed. São Paulo: Ática 1980.

NABAIS, P. "Introdução a Uma Família Inglesa". Lisboa: Ulisseia, 1998.

NEMÉSIO, V. "Prefácio a O Bobo". Lisboa: Bertrand, 1972. "Prefácio a Eurico, o Presbítero". São Paulo: DIFEL, 1969.

OMAYA, M. H. V. D. O Haiti como Locus Ficcional da Identidade Caribenha: Olhares Transnacionais em Carpentier, Cesaire e Glissant. Tese (Universidade Federal 
fluminense: Niterói, 2009)

PEDROSA, C.. Antonio Candido: a palavra empenhada. São Paulo: Edusp, 1994.

. "Os Dois Gumes da História" In: D’INCAO, M A.; ScARABOtOLO, E. F. (org.)

Dentro do texto, dentro da vida; ensaios sobre Antonio Candido. São Paulo: Cia das Letras, 1992. p. 129-34.

PRADO, A. "Dimensão crítica da Formação".In: SERNA, J. de la (org.) História e literatura: homenagem a Antonio Candido. São Paulo: Unicamp, 2003, p.417-34.

REIS, C.; LOPES, A. C. Dicionário de Narratologia. 4. ed. Coimbra: Livraria Almedina, 1994.

REIS, C ; PIRES, M. N.. Historia Critica da Literatura Portuguesa -O Romantismo. Coimbra: Verbo, s/d.

REIS, C. História Crítica da Literatura Portuguesa V - Romantismo. Lisboa: Verbo, 1993.

"Introdução a Eurico, o Presbítero". Lisboa: Ulisseia, 1994.

ROMANO, L. Literatura cabo-verdiana. Ocidente. Lisboa 70 ((335): 103-16, 1966.

RUIZ, R. da S. Sapatos: imagem fetiche na arte contemporânea. IN: Revista, Pos LPC, CEARTE - UDESC, Santa Catarina, 2004. Disponível em:<http://www.udesc.br/centros/ceart/hp/Pos_Graduacao/Revista/Pos-LPC/ artigos/ renato_ruiz/sapatos.htm>. Acesso em: 23 jan. 2005.

KODA . História: Sapatos On Line, 2000. Disponível em: <http://www.sapatosonline.com.br/>. Acesso em: 23 jan. 2005.

SÀ, Victor de. Esboço Histórico das Ciencias Sociais em Portugal. Lisboa: Instituto da 
Cultura, 1982.

SANTOS M. E. S; TORRAO, M. M. F.; SOARES, M. J. S. (org) Historia Concisa de Cabo Verde. Lisboa-Praia: IICT e IIPC, 2007.

SANTOS, M. E. M.; ALBUQUERQUE, L. de. (coord). Historia Geral de Cabo Verde. Lisboa: Instituto de investigação Cientifica Tropical de Portugal: Praia: Instituto de Investigação em Cabo Verde, 2001, V1, p.23-39.

SANTILLI, M. A. Africanidades: contornos literários. São Paulo: Ática, 1985. . Estórias Africanas: História e Antologia. São Paulo: Ática, 1996.

SARAIVA, A. J. A Cultura em Portugal. Lisboa: Gradiva, 1994.

SARAIVA, A. J.; LOPES, O. História da Literatura Portuguesa. 5. ed. Porto: Porto Editora, 1972.

SCHWARCZ, L. M. O espetáculo das raças: cientistas, instituições e questão racial no Brasil -1870-1930. São Paulo: Cia das Letras, 1993.

SILVA, C. F. da.; GOMES, L. de F. Oroonoko, da escravidão ao erotismo. Maceió: Universidade Federal de Alagoas, 2003.

SILVA, A. C. e S. A África explicada aos meus filhos. Rio de Janeiro: Agir, 2006.

SIMÕES, J. G. História do Romance Português. Lisboa: Estúdios Cor, 1969. v. 2.

SOBRERA, L. A. R. Uma Imagem do Campo Literário Português no período Romântico - contributo para a História da literatura produzida em Portugal entre 1840 e 1860. Dissertação ( Mestrado em Literatura Portuguesa)- Faculdade de Letras de Lisboa, 1998. 
SERRÂO, J.; MARQUES, A. H de O. (org) (1988 e 2001). Nova História da Expansão Portuguesa. Lisboa: Editorial Estampa. Vols 10 (1988) e 11(2001)

TEGARRINHA, J. (org) MATTOSSO (et.al.). História de Portugal. São Paulo: EDUSC, 1989.

VASCONCELOS, S. G. Dez Lições Sobre o Romance Inglês do Século XVIII. São Paulo: Boitempo, 2000.

VIMALA, D.; SEABRA, M. A Literatura Indo-Portuguesa. Lisboa: Junta de Investigações do Ultramar, 1971, 2 v.

\section{OBRAS CONSULTADAS}

ABDALA, JUNIOR, B. Literatura, História e Política. São Paulo: Ática,1989.

Fronteiras Multiplas e Identidades Plurais: um ensaio sobre mestiçagem e hibridismo cultural. São Paulo: SENAC, 2002.

ABDALA, B; SCAPELLI, M. (org.) Portos Flutuantes: trânsitos ibero-afro-americanos. Cotia, São Paulo: Ateliê Editorial, 2004

ANDRADE, M. P. de. Origens do Nacionalismo Africano. Lisboa: Publicações Dom Quixote, 1998.

ARENDT, H. Sobre a violência. Rio de Janeiro: Relume/Dumará, 2001.

BANTON, M. A idéia de raça. São Paulo: Ediçoes 70, 1977.

BARBOSA, J. Arquipélago. S. Vicente: Edições Claridade, 1935. 
BENJAMIN, W. Magia e Técnica, arte e Política: Ensaios sobre literatura e História da Cultura. 7.ed. Trad. Sergio Paulo Rouanet; Prefácio Jeanne Marie Gagnebin. São Paulo: Brasiliense, 1994.

BHABHA, Homi "A questão do outro. Diferença, discriminação e o discurso do colonialismo". In: Holanda, Buarque de. (org) Pós-modernismo e Politica. Rio de Janeiro: Rocco, 1992.

BOURNEUF, R; QUELLET, R. O Universo do Romance. Trad. José Carlos Seabra Pereira. Coimbra: Almedina, 1976.

CANIATO, B. J. Percurso pela África e Macau. Cotia: Ateliê Editorial, 2005.

CANDIDO, Antonio. A Personagem de Ficção. 9. ed. São Paulo: Perspectiva, 1993.

CHALHOUB, S. Visões de Liberdade: Uma História das últimas décadas da Escravidão na Corte. São Paulo: Cia das Letras, 1990.

CHAVES, R. A Formação do Romance Angolano. Entre intenções e gestos. Maputo; In: Via Atlântica, São Paulo: FBLP; 1999.

EVEn-ZohaR, I. "Polysystem Studies", Fragmento in "Papers in Culture Research". The Porter Chair of Semiotics, Tel Aviv: Tel Aviv University, p. 38-49, 2005.

FANON, F. Peau Noire et masques blancs. Paris: Seuil, 1952.

FANON, F. Em defesa da Revolução Africana. Lisboa: Livraria Sá da Costa. Ed., 1980.

FERREIRA, M. A Aventura Crioula. 3. ed. Lisboa: Plátano Editora, 1985. .Literaturas Africanas de Expressão Portuguesa. São Paulo: Ática, 1987. .O Discurso no percurso Africano I. Lisboa: Plátano, 1989.

GORENDER, J.. A Escravidão Reabilitada. São Paulo, Ática, 1990. 
HAMILTON, R. G. Literatura Africana, literatura necessária II-Moçambique, Cabo Verde, Guiné-Bissau, São Tomé e Principe. Lisboa:Edições 70, 1984.

LARANJEIRA, P. De Letras em Riste: identidade, autonomia e outras questões nas literaturas de Angola, Cabo Verde, Moçambique e São Tomé e Principe. Porto: Afrontamento, 1992.

LARANJEIRA, P. Literaturas Africanas de Expressão Portuguesa. Lisboa: Universidade Aberta, 1995.

LOWY, M. Revolta e Melancolia: o romantismo na contramão da modernidade. Trad. Guilherme João de Almeida Teixeira. RJ: Vozes, 1995.

NITRINI, S. Literatura Comparada. São Paulo: Universidade de São Paulo, 1957.

PAZ, O. Os Filhos do Barro. São Paulo: Ateliê, 1984.

REIS, C. Introdução à Leitura das Viagens na Minha Terra. Coimbra: Almedina, 1998.

\section{OBRAS DE REFERÊNCIA}

AZEVEDO, Francisco Ferreira dos Santos. Dicionário Analógico da Língua Portuguesa: idéias afins. RJ: Lexikon, 2010.

BORBA, Francisco da Silva. Dicionário Gramatical de Verbos do português contemporâneo do Brasil. Academia Brasileira de Letras. 2 ed. São Paulo:Unesp, 1991. 
DICIONÁRIO Escolar da Língua Portuguesa. Academia Brasileira de Letras. 2 ed. São Paulo:Companhia Editora Nacional, 2008.

HOUAISS, A. Dicionário Houaiss da Língua Portuguesa. Rio de janeiro: Objetiva, 2001.

VOCABULÁRIO Ortográfico da Língua Portuguesa. Academia Brasileira de Letras. 5 ed. São Paulo:Global, 2009. 